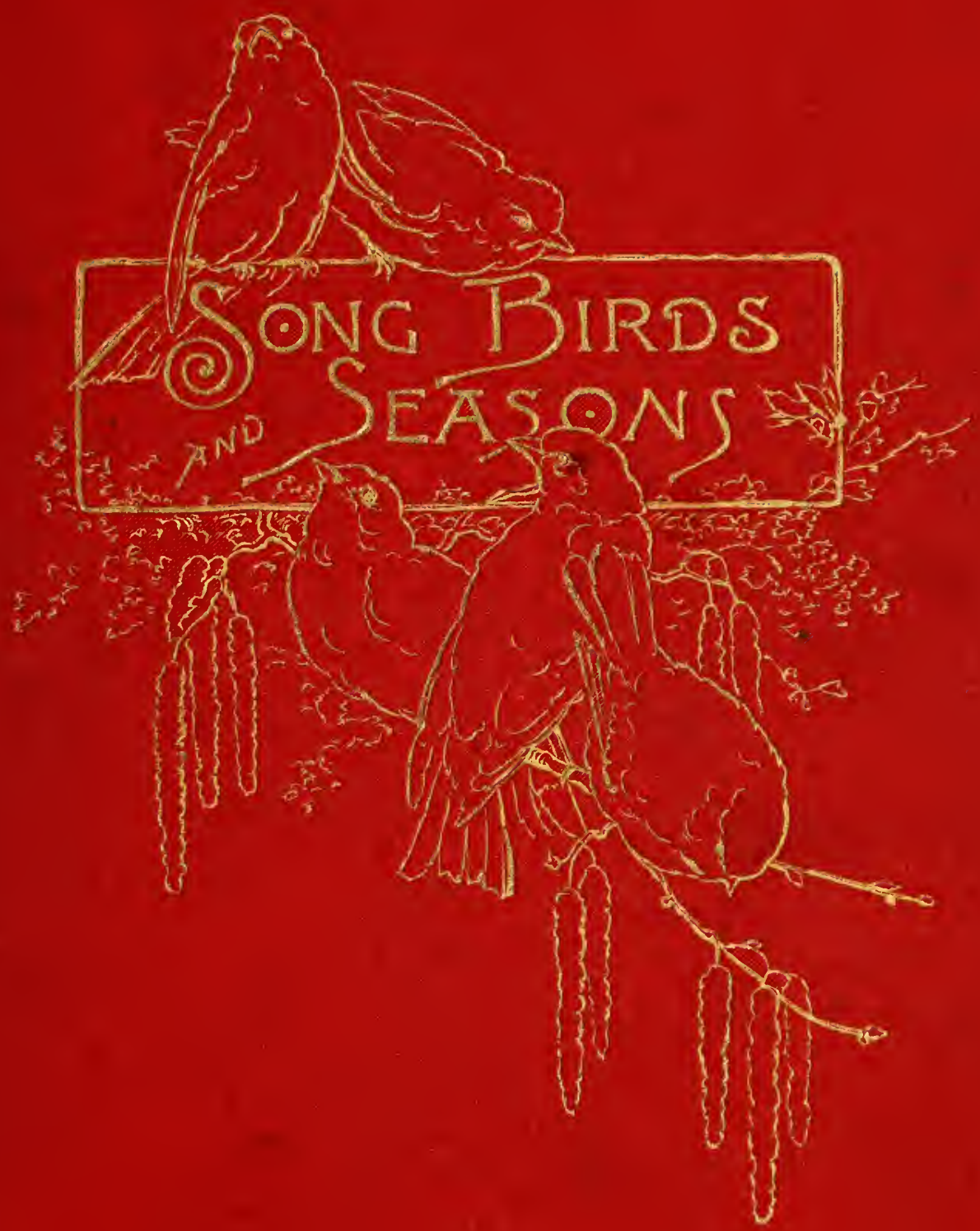




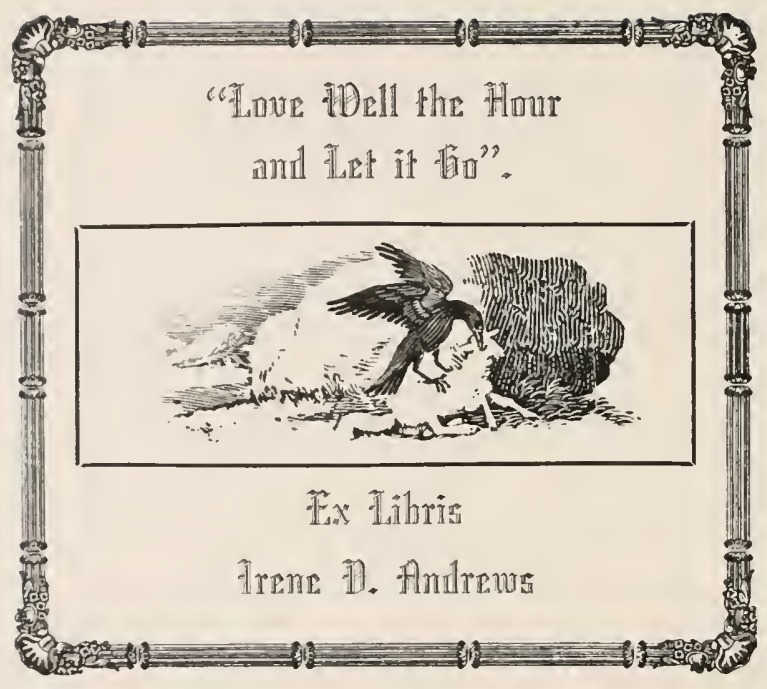








\section{Song Birds and Seasons}

BY

ANDRÉ THEURIET

ILLUSTRATED BY HECTOR GIACOMELLI

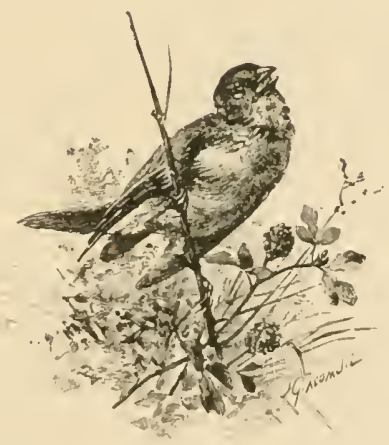

$$
\text { B OST ON }
$$

ESTES AND LAURIAT 
Copyright, 1888,

By Estes and Lauriat.

PRESSWUK BY JUIIN WILSUN AND SON, UNIVRSITY PRESS. 


\section{LIST OF ILLUSTRATIONS.}

\section{SYMPHONY OF SPRING.}

PAGE

Border. . . . . . . . . Goldfinch, bullfinch, greenfinch, warblers
Healpiere . . . . . . . The concert . . . . . . . . .

Initial Illustration . . . . . Finch in its bower . . . . . . . xj

Tailpiece . . . . . . . Wren . . . . . . . . . . . xvi

\section{THE FINCH.}

Borler. . . . . . . . . Young finches . . . . . . . . . 1

Headpiece and Initial Illustration Finch calling its little ones . . . . 3

Full-page Illustration . . . . The finch and its nest . . . . . . 7

Tailpiece . . . . . . . The finch of Ardennes . . . . . . 10

\section{THE IVARBLER.}

Border . . . . . . . . Young warblers . . . . . . . . 11

Headpiece and Initial Illustration The open bills . . . . . . . . . 13

Full-page Illustration . . . . Black-headed warbler . . . . . . 17

Tailpiece . . . . . . . Warbler's nest . . . . . . . 20

\section{THE NIGHTINGALE.}

Border . . . . . . . . Young nightingales . . . . . . . 21

Headpiece. . . . . . . . Hymn to the moon . . . . . . . 23

Initial Illustration . . . . . Song of love . . . . . . . . . . 23

Full-page lllustration . . . . The nightingale . . . . . . . . 27

Tailpiece . . . . . . . Warbler's nest. . . . . . . . . 30 


\section{THE, GOLDFINCH.}

Border . . . . . . . The first flight . . . . . . 31

ITendpiere . . . . . . . The nest . . . . . . . . . 33

Initial lllustration . . . . . Goldfinch picking a thistle . . . . 3:3

Full-page lllustrution . . . . Goldfinch . . . . . . . . . . 37

Tailpiece . . . . . . . The galley-slave . . . . . . . 40

THE LINNET AND THE SISKIN.

Porder . . . . . . . . . Young linnets . . . . . . . . . 41

Ileudpiece. . . . . . . . On the hedge . . . . . . . . . 4:3

Initial lllustration . . . . The first eggs . . . . . . . . . 43

I'ull-page Illustration . . . . Limnet's nest . . . . . . . . . 47

Truilpiece . . . . . . . The siskin . . . . . . . . 50

TIE GOLDHAMMLR.

liorder . . . . . . . The nest and nestlings . . . . . . 51

IIeadpiece . . . . . . . The sorb-apples . . . . . . . . 53

Initial Illustration . . . . . The cherries . . . . . . . . . 53

Full-page Illustration . . . . The goldhammer . . . . . . . . 5 5

Tailpiere . . . . . . . Female goldhammer . . . . . . 60

THE KING-FISIIER.

Pirmler . . . . . . . The young of the ling-fisher . . . 61

IIecolpiere. . . . . . . . The ambuscade . . . . . . . 63

Initial Illustratim . . . . . King-fisher diving . . . . . . . 63

Full-page Illustration . . . . King-fisher . . . . . . . . . . 6 \%

Tailpiere . . . . . . A good prey . . . . . . . . 70

\section{THE SPARROW.}

Porrler . . . . . . . Young sparrows . . . . . . 71

Herrlpiece. . . . . . . . The assembly . . . . . . . . . 73

Initial Illustration . . . . . On the roof . . . . . . . . . . 73

Full-page Illustration . . . . In the fields . . . . . . . . . 77

Tailpiece . . . . . . . The herlge-sparrow . . . . . . 80 
THE WAGTAIL.

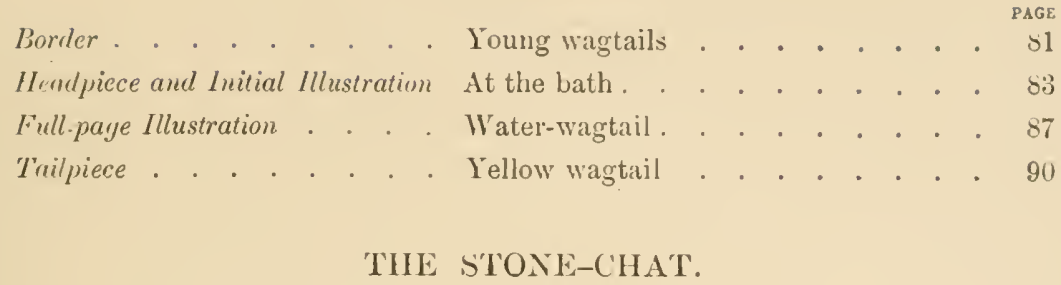

Border . . . . . . . . The stone-chat's song . . . . . 91

Headpiece. . . . . . . . Ploughed land. . . . . . . . . 93

Initial Illustration . . . . . At the edge of the field . . . . . 93

Full-page Illustration . . . . Hedge stone-chat's nest . . . . . 97

Tailpiece . . . . . Heath stone-chat . . . . . 100

THE NUT-HATCH AND TIE LESSER WOODPECKER.

Burder . . . . . . . . The nut-hatches . . . . . . 101

Headpiece and Initial Illustration The purveyors of the little birds . . . 103

Full-page Illnstration . . . . The nut-hatch . . . . . . . . 107

Tailpiece . . . . . . The woodpecker . . . . . . 110

\section{THE IAARK.}

Border . . . . . . . The lark's little ones . . . . . . 111

Ileadpiece and Initial Hllnstration Morning . . . . . . . . . . . 11:3

Full-page Illustration . . . . Lark soaring . . . . . . . . . 117

Tailpiece . . . . . . . The young brood . . . . . . 120

\section{THE RED-S'TART.}

Border. . . . . . . . . In the nest . . . . . . . . . 121

Headpiece and Initial Illustratiom The siesta . . . . . . . . . . 12:;

Full-page Illustration . . . . The red-start . . . . . . . . . 122

Trailpiece . . . . . The blue-breast . . . . . 130 


\section{THE BULLFINCH.}

The nest- PAGE

Hecalpiece. . . . . . . . On the branches . . . . . . . . 193

Initial Illustration . . . . . Young bullfinches . . . . . . . 133

Full-page Illustration . . . . Bullfinches on the wing. . . . . . 137

Trilpiece . . . . . . Twee-twee-twee . . . . . . 140

THE 'THRUSH.

Border. . . . . . . . On the watch . . . . . . . . 141

Ileadpiece and Initial Illustration On the vine . . . . . . . . . 143

Full-page Illustration . . . . The thrush . . . . . . . . . . 147

Tailpiece . . . . . . . The mavis . . . . . . . . . 150

THE SWALIOW.

Border . . . . . . . . Young swallows . . . . . . 151

Headpiece and Initial Illustration A telegraph wire . . . . . . . . 153

Full-page Illustration . . . . In the open sky . . . . . . . . 157

Tailpiece . . . . . . Dead . . . . . . . 160

THE RED-BREAST.

Border . . . . . . . . Young rell-breasts . . . . . . 161

Headpiece . . . . . . . . In quest of shelter . . . . . . . 163

Initial Illustration . . . . . The nest . . . . . . . . . . 163

Full-page Illustration . . . . First snow . . . . . . . . . 167

Tailpiece . . . . . . Leaving the nest . . . . . . 170

THE TITMOUSE FAMILY.

Border . . . . . . . . Young blue titmice . . . . . . 171

Henrlpiece. . . . . . . Winter . . . . . . . . 173

Initial Illustration . . . . . Great titmonse . . . . . . . . 173

Full-page lllustration . . . . Great black headed titmouse . . . . 177

Tailpice . . . . . C Crested titmonse . . . . . . 180 


\section{THE WREN AND THE TROGLODY'TE.}

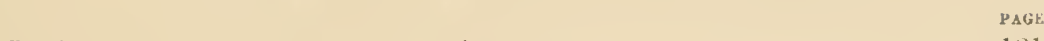

Border . . . . . . . . . A prey . . . . . . . . . . 181

Headpiece. . . . . . . Wrens (the rivals) . . . . . . 18\%

Initial Illustration . . . . . Wren and her little ones . . . . . 18:3

Full-page Illustration . . . . Wren's nest . . . . . . . . . 187

Tailpiece . . . . . . . Troglodyte . . . . . . . . 190

\section{THE BLACKBHLD.}

Border . . . . . . . . . Young blackbirds. . . . . . . . 191

Headpiece. . . . . . . . Across the fields . . . . . . . 193

Initial Illustration . . . . . On the branches . . . . . . . . 193

F'ull-page Illustration . . . . Spring shower . . . . . . . . 197

Tailpiece . . . . . . . The ouzel . . . . . . . . 200

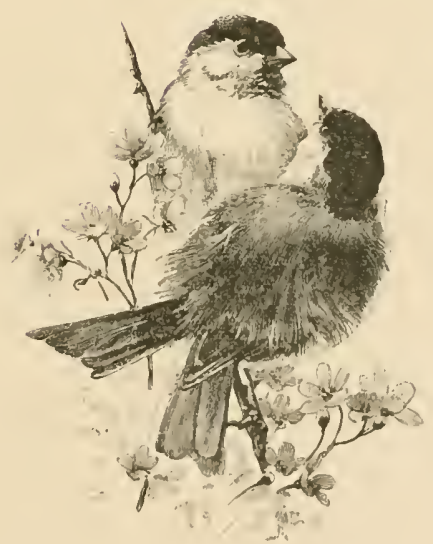





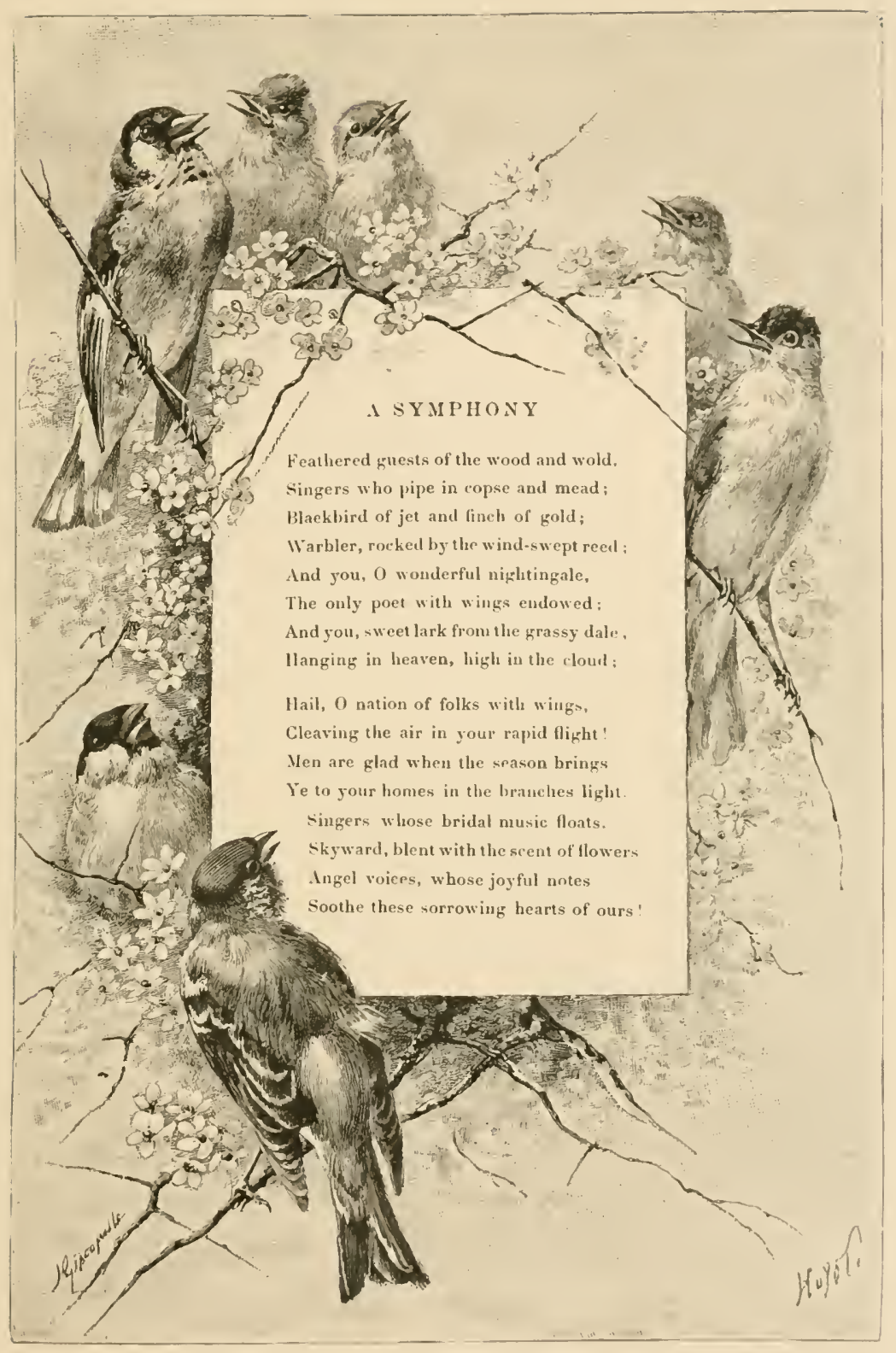





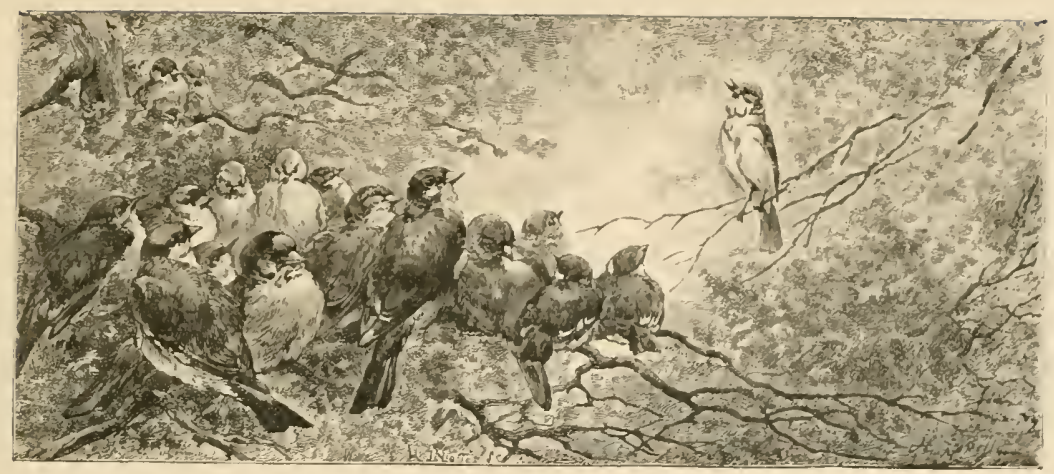

\section{A SYMPHONY OF SPRING}

At first an almost insensible rustling, a scurcely perceptible thrill runs through the forest, litie the mysterious murmur of growing grass, of opening leaves and of rising sap; - then, on the skirt of the copplice where the yellow cornelian-tree is in full bloom, at the bottom of the moist walleys where the laurel unfurts its pinti corolla, three notes burst forth, three joyous, quick, shupp redoubled notes: it is the first awreliening of the songasters of the woods, the blacklbird that whistles his merry song to the newly budeling trees, litien a boy led ome of school shouring 
(1) all the nooks of the forest: "Merrily! merrily! let us injoy ourselves; spring has come back; to-day is Saint1/ban's day, when every bird has chosen the place of its nest!' Two rovices respond to this merry companion: one, at the same time soft and thrilling bursts forth from the shadiest coserts, 't is that of the finch; - the other, clear, wild and joyful is that of the blacki-cap. These wo newcomers sing but a short strain, but they repeat it to saticty, as if they folt the need of consineing themsetves that winter is really gone and that in spite of Aprit showers spring has not been countermanded.

Down below, in the plain where wheat and rye are growing green, hundreds of acrial, melodious s'oices confirm this good new's. It is the morning choress of sliy-larlis. At breati of elay, the first ane awalie soars upwards rising in a straight line as high as possible, litie the sailor on the outlooli at the top "f the highest mast, and proclaims to all its lind that the season of love and nest building has come; then it falls straight down litie the plumb line intu the grossiest furrows. Another stiylarl: soars upwards, then a third, then twenty others; you can harlly perceive them up abose in the rosy purple of the rising sun; but you can hear their distant melody, the notes of which seem to drop down litie shining pearts from a string.

The signal for the concert is now given. From every nnoli and corner, from the hedges on the road-side, from 
the full-blown fruit trees of the orehard, from the low banks of the river, from the shady glens of the forest, a marvellous ensemble fills the resonant atmosphere: the trills of the goldfinch, the chirping of the linnet and the titmouse, the runs of the thrush, the tremolo of the hoopoo, the interlude of the bullfinch, the soft shrill of the wren and the nut-hatch. Then, at intervals, breaking in upon this unceasing variety of sound, twe grave deep, dreamy, redoubled notes ring through the thichiness of the forest.

It is the roice of the cuclion, that invisible, fanciful singer that you hear almost at the same time in all the nooks and corners of the wood, and his song seems to rythm the flight of time. You think him quile near, you seck him and suddenly his somorous appeal bursts forth from afar. It is he who throw's a melancholy note into this concert of universa' joyy. This full and mysterious double note, which ever seems to die away and which constantly resounds again, is like an echo of ranished springs and of forgotten friendships. It seems to sigh: "Remember! remember! Give a thought to those who have gone for ever, to the memory of those beloved beings who can no more taste the rapture of the rerival of nature. Time flies and carries you along... For you also, spring will not bloom always!" But in spite of the prognostics of this melancholy, capricious ararner, the joyful merriinent of the light-hearted tribe bursts forth ever and anom 
in an eruberance of song. Leaves are growing, lilirs of the valley perfume the air, nests are being built everywhere: in the grass, in the hedges, in the hollow of dead trees, in the branches of green bonghs, and every one thinkis only of the delights of the present hour.

Now the blacti and white swallows, with their pointed, arrow-like wings, come out of all the streets of the village. These fearless travellers rome from afar and manifest their joy of bring home again by the most astomishing circuits. Air-atrintiers as they are, they brush past the top of roofs, stim along the ground, disappear under the arches of the bridges and reappear suddenly in the bright sun-light; they seer about, rise, fly up and down without ever perching and hardly uttering the slightest sound. The silent danre of these blact sypsies is like an intermesso in the symphon!y of spring. It is the ballet in the middle of the concert.

Meanwhile yonder, in the forest, the singing continues. From the bottom of the thicliet the cooing of the wild woodpigeon, at once low and tender, loud and yet clouded comes towards us. The passionate, langurshing note rises, falls, rises again; you seem to hrar the sleepy forest utter unconscious sighs in its dream. This is no longer the joyous greeting of the stiy-larli at early dawn, nor the sprightly prattle of the black-bird, nor the sonorous call of the cuction; it is the intimate talli of a losing married couple, who exchange tender and caressing vow's, happy 
in their conjugal felicity. The wood-pigeons coo on hechless of their surroundings; they give themselses up to their mutual tenderness and like the loners in La Fontaine's frable :

Ils se sont l'un à l'aulie un monde toujours beau,

Toujou's divers, loujours nouveau...

But now the shadow's are tengthening on the fields; the stiy reftects a deeper asure hue in the ponds; the thiclicts assume a rodder tint and the first trinkling star trembles abose the horizon. The soices grow fainter and fainter, the birds fall asleep nerr their nests. You would thinti that the concert is going to end, but it is only a temporary hash, a cleverly managed panse to prepare the entrance of the grand artist of spring.

The nightingale sings, and Nature herself seems to be listening. The admirable strains of this master solist fill up the whole interwal from night-fall to da!y-breati. Beside him all other performers retire into shate; listening to him, you forget their humble songs, just as the sweet scented, milli-nhite lily of the valley obliterates the remembrance of April flowerets. With the song of the nightingale the anchantment of fairy-land begins to reign in the roods. His hymn is the song of tyremnical, riolent, passionate, tender and sensuous love. You never grow tired of hearing this song, you would have it last foresere.

But nothing lasts forever. T'owards the middle of dune the breath of the master artist grons shorter, and when 
the midsummer sun shines an the fields his powerful voice is no longer heard in the night. Earlier yet than he the wrarblers have ceased their song. One bird alone, the rhattering warbler utters its deafenings, rulgar melopocia, among the willows by the river bathed in sunstrue; its unisy music rises abose the slisteming waters, abore the transparent blaze of the fiery atmosphere, white down yomeder, among the ripe cherries of the orehard the goldfinch deinlis in the perfumed juice, searcely able to theow ont there flute-lilie, lispring notes. These are the last songsters of the sertson, and their sun-turrmed stiains end the "symphon!y of spring ».

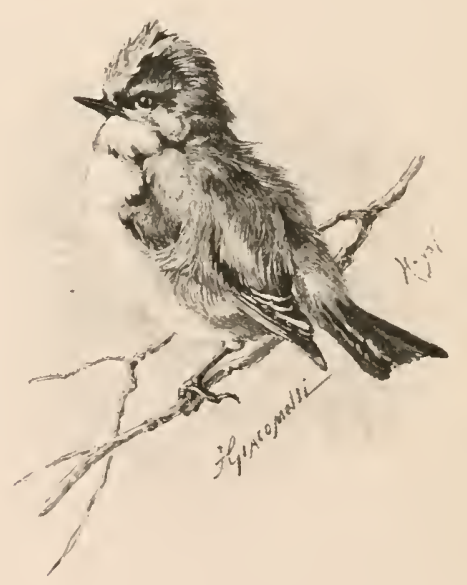




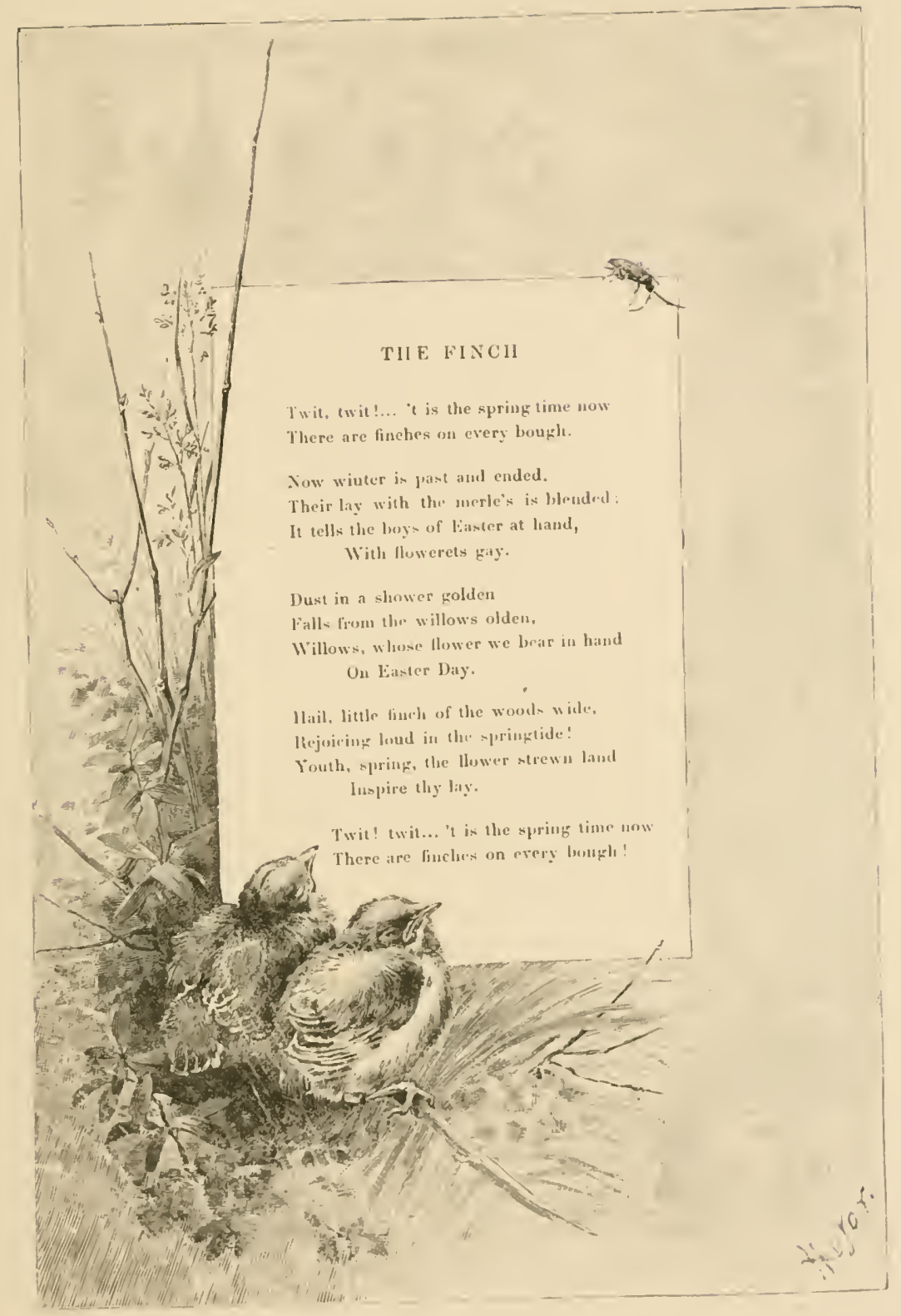





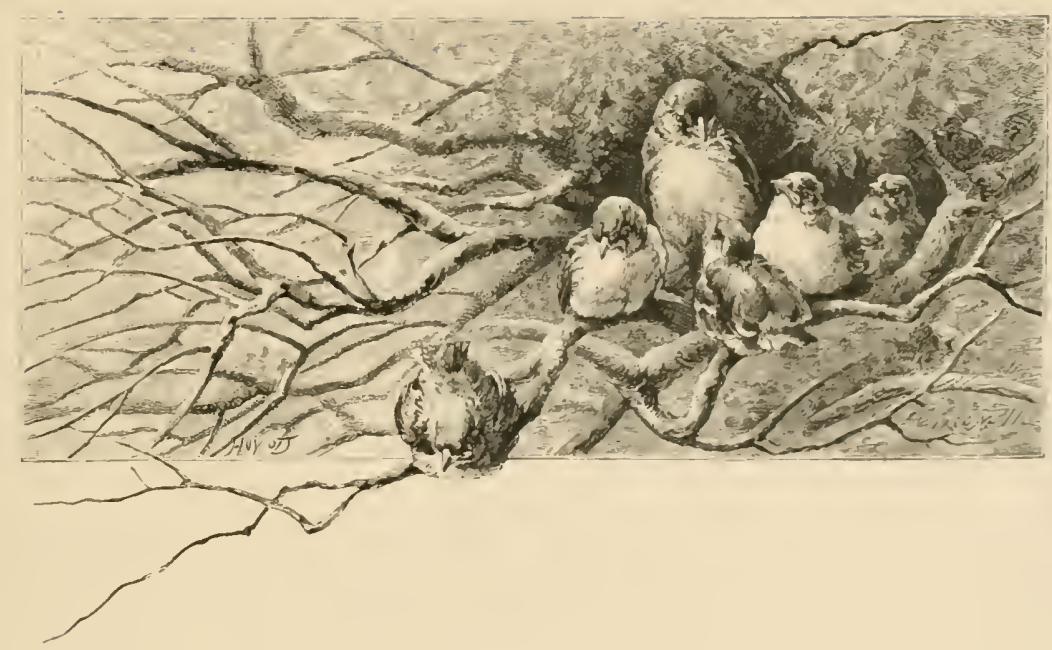

THE FINGH

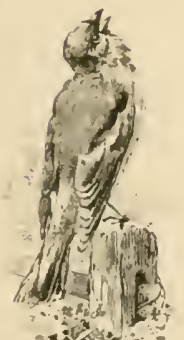

Taking a walk in the woods on one of the first fine days of March, I heard in the distance the merry song of a bird. At that time of the year the leafless forest has the sonority of an empty dwelling and that early song A) rang joyously through the woods like the forerumer of coming spring. The song consisted of three parts : a lively prelude, a trill and a final modulation with a powerful, delicate sound. I recognized the song of the finch, and that strain of early spring brought back to my mind a remembrance of childhood, which seemed to rise from afar, like the song, from the very depths of the forest. 
At that time, being eleven years old, I used to lay snares for young birds in a coppice belonging to my grandfather. These snares are very common in the province of Lorraine, especially from september to November, the time of passage. All the small fry of birds are sure to be taken in these traps, especially in the cruel one that La Fontaine calls "Regingletle " and which in our parts is called the "Girasshopper" ).

This snare consists of a supple hazel switch curred like a racket, the two ends of which are brought together by a double cord. These rackets are placed edgewise along the paths or the ponds frequented by birds, every twenty feet. Some of the more skilled snarelayers cven fasten a bunch of sorberries above the racket as a bait. Early in the morning and late at night, some sharp billed bird is sure to come and drink in the pond tempted by the treacherous appearance of that inviting pereh: they settle on it, a peg comes down with a dry noise, and the poor creature is raught in the suddenly tightened slip knot and hangs suspended by its bruised members at the top of the unstrung racket.

One evening as my grandfather and I were taking our last walk, I heard some sharp cries in a footpath close by and I saw a bird just caught in one of our "Grasshoppers ". It was about the size of a sparrow and it fluttered so furiously that it had almost overset 
the racket. Nevertheless, it had not been injured, perhaps the cord hat not snapped back as suddenly as usual, or the feet of the victim had been more resistant Its back was ehestnut-coloured. the top of its head and its bill bluish drab; it had bright eres, black mustachios; its neek, breast and sides were of a fine wine colour, its rump of a dark olive shade; it had besides a forked tail and a white spot on each wing.

"It is a finch from the Ardennes, " said my grandfather. I knew it already, for haring taken it by its wings so as to set it free, it had bitten me to the blood. My grandfather observed to me that its feet had not been broken, one only being slightly scratched. When I saw how lively and pretty it was, I thought I should like to put it into a case and tame it. I begged to be allowed to take it home and I insisted so well that the permission was granted. "Very well ", said my grandfather, shaking his head; "but you will surely never be able to bring it up; it is already too strong and too wild $n$.

Of course I did not believe him, being at that presumptions age when we have no doulus about anything. I wrapped the finch up in my handkerehief and as soon as we got home I placed it in a well closed wicker basket until I conld prepare a cange for it the next day.

I passed half the night without being able to sleep. 
as the thought of my prisoner kept running in my head. I had heard that finches have a marvelous musical aptitude and that with patience one can train them to be regular artists; so that when my eyes closed at last, I heard my pupil singing in my dreams like the blue bird of fairy-land. At dawn I ran to my basket. The finch had scarcely slept better than I; it was fluttering about sullenly, pecking furiously at the sides of the basket. I spent all the money I had saved on a eage containing a trough and a manger which I filled with hempsced. I moved my bird into its cage and while it was getting acenstomed to its new dwelling, I climbed into our garret, where I consulted some old volumes on ornithologry, so as to get well arquainted with the habits and tasies of my guest.

There I learned that finches are naturally very merry. that they sing early in the spring, long before the nightingale, and that besides their regular song, they throw out three peculiar notes: a cry of appeal at the time of courtship, a war ery when they fight against a rival, and finally, when it is going to rain, a long wail which is a certain prognostic of bad weather. I saw besides that finches build their nests in the most thickly spreading trees: these nests are round, solidly woven of moss on the outside, of hair and spider-wobs on the inside; the female lays five or six red hrown egg's spotted with black at the broader 


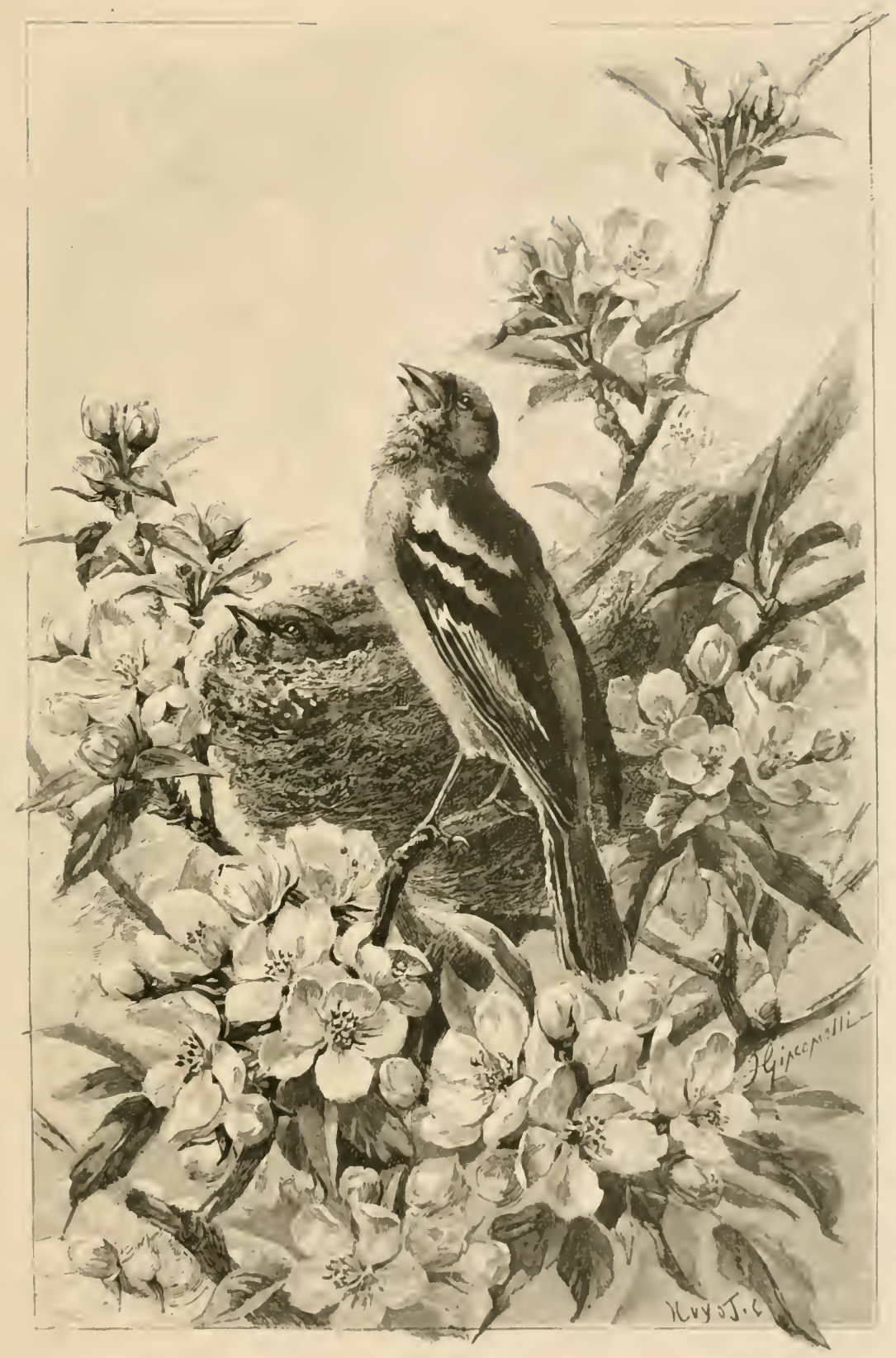

'HE FISCH 

end; the male remains patiently near his mate, feeding their young with insects and caterpillars; my author added that adult finches feed on seeds, such as poppies, mast and grain.

Thus well informed. I returned to the rage. The prisoner did not at all seem inclined to get used to it. Clutching at the bars, fluttering incessantly, he had upset the trough and disdained the hemp-seed which filled the manger. I thought perhaps the bird did not like its fare. my book having spoken of poppies and mast. I ran into the fields to search for this food; when I came back the fererish agitation of the prisoner had redoubled. It continued throwing itself against the bars in a state of great rage, bruising its pretty bluish head, breaking the feathers of its tail, while the bristled down of its chest was flying about the air. From time to time, being out of breath it would huddle itself up in a corner, opening wide its deep black eyes and its despairing glance seemed to cry out to me: "Set me free! oh set me free!" I turned a deaf ear to its mute appeal and left it, beguiling myself with the hope that the night would calm it. At day-break I ran again to my cage... there lay the finch, already stiffened, on the bottom hoard of the cage, with closed eyelids, bristled dull plumage, dead amidst the scattered seeds it had left untouched. The wild bird of the mountain, hating its prison, had starved itself to death. 
My hearl failed me, for the cruel agony of the poor bird weighed on my conscicnec. For a long while I could not see a bird without feeling strangely uneasy. And to(lay still, after so many years, while I was listening to the early trills of the fincle in the brushwood, this remembrance of my ahildhood come back to my mind with the bitter taste of remorse.

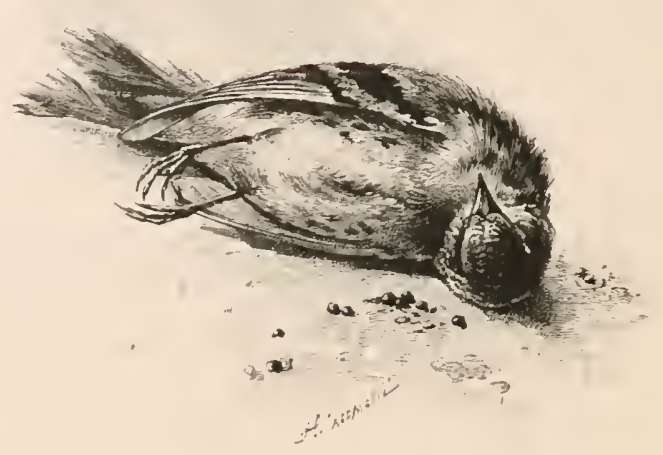




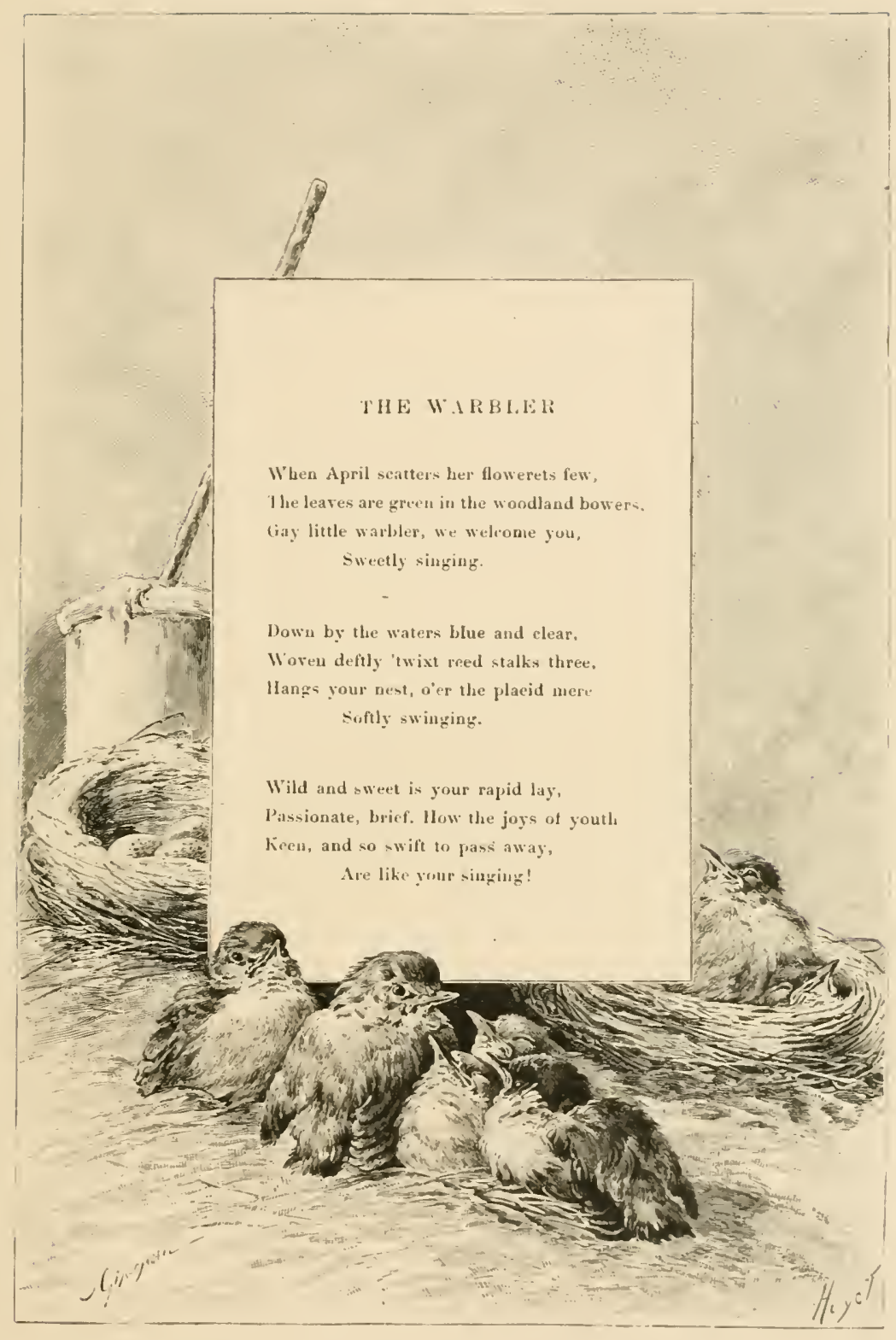





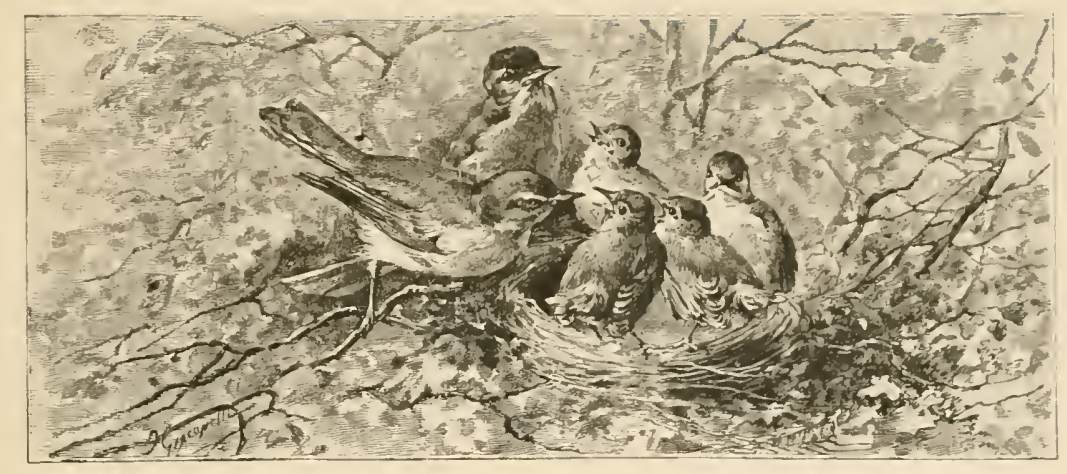

\section{THE IVARBLER}

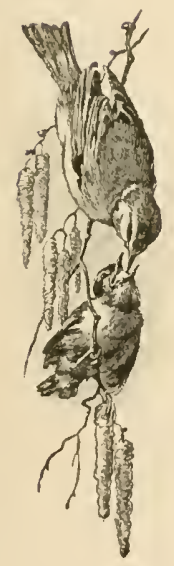

Of all sylvan birds the warbler is the one with which we are the most familiar. If we have ever lived in the comtry, we have surely known one or two. The tribe of wablers is numerous: the grey warbler, the black (ap) and the whole class of reed varblers that includes the great sedge warbler, the marsh warbler, and the white throat.

The grey warbler is the largest and most common of all. It generally lives in garelens, orchards, bean and pea fields. It perches on the sticks which sustain these creeping vegetables; there it plays its gambols and builds its nest. It remains there till harvest tıme. 
which coincides generally with the period of migration. During the season of (omblip) and brooding these wreath and flower-covered boughs resound with light melodies. and these joyous marriage songs hamonize sweety with the tender enreen of the peas, the delicate blossoms of which resemble a thight of white butterflies.

The black (ap) is the best known warbler and the most gifted as regards gath and song. When fully grown, ils black hood covers the rown of its head and falls over ils eyes: around the meck the plumage is state coloured, getling lighter towards the rhest, it is white on the breast with a slight shate of black: the back and wings are grevish brown, with a light olive tint.

The song of the hlack (ap) is sweet and sustained. It consists of a series of short, brisk and clear modufations: some rather louder notes are heard in the soft, sweet strain, then all is blended again in a soft lwittring. It is tmoly the langwage of the first emotions in spring, al once livety and discreet. 't is the song of the youth of the reat. When the quick joyous notes of the wathler resomel in hazel and cherrytrees. school-boys say : " Winter is passing away," and suddenly playing tmants, they wander about in hands. roving about the woods, basking in the sum. sceking for nests and cutting whistles in the willow branches moist with sap. 
As for me, I can never hear the song of this warbler without remembering the whole series of rustic pleasures which the burden of its strain promised me in my turbulent childhood. It calls to my mind my father's garden with its thick border of rasploerry bushes, its boxwood and juniper trees scattered about the walks. In the heart of one of these juniper trees, I discorered one morning the nest of a black eap warbler. Placed at the root of the branclies, hardly two feet from the ground, it consisted on the outside of moss and dry grass, inside, of fincly interworen hair. This nest contained five light brown, spotted eggs with darker veins. I could not resist the manghty childish caprice of stealing one of the pretly spotted eggs. The next day when I came to wateh the brooding mother, I found that the egg's were broken and the nest abandoned.

Warbler's are unnanageable on this point: as soon as the hand of a stranger has broken in upon the mystery of their nest, considering the intrusion of this unknown enemy as an ill omen for their future family, they prefer destroying the whole, beginning to lay their roges elsewhere where the brood will be less unlucky. Both father and mother watch their progeniture with equal solicitude, relieving each other to brood and slowing an attachment to their newly hatched young which lasts as long an the scason. They keep their young fledg- 
lings near them. You ran see them tlying about the skirt of the woods, the father ahead as a seout: if he perecives an abundant harvest of wild gooseberries or olderberries in the bushes, he gives notice of it to his family by a joyous romire and the whole tronp hastens thither to partake of the feast.

'The habits of the reed-warblers are very different. The great sedge warlelep prefers dwelling among swampy wooded bankis: the mash-warhler prefers gardens and fields neall rumning watere: the white throat prefers to dwell amomeng the willows near rese and hemp fields. 'There ale some trats common to them all; they all have a flattened head like the swallow, a strong bill and a long and robust thumb mal: they all feed exclusively on those insecels which abound in the neighbourhood of water ; they all have the same yellowish gerey plumage and the same shrill. sharp notes in their song.

Their dece) nests are artistically huilt, skilfully woven on the ontside and inside with dry supple grasises. They gererally suspend them on lwo or three stemstied together ly as many ring of moss and hair: these moveable loops are loose enowerh to allow the nest to rise and fall alceordinge to the height of the waters.

In this acrial dwelling which the rement and the slightest hreeze sway to and fro. the female lays five eneam

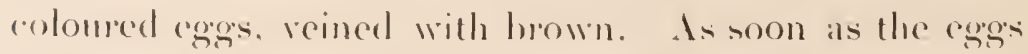
are laid, she does not again leave her nest, but allows it 


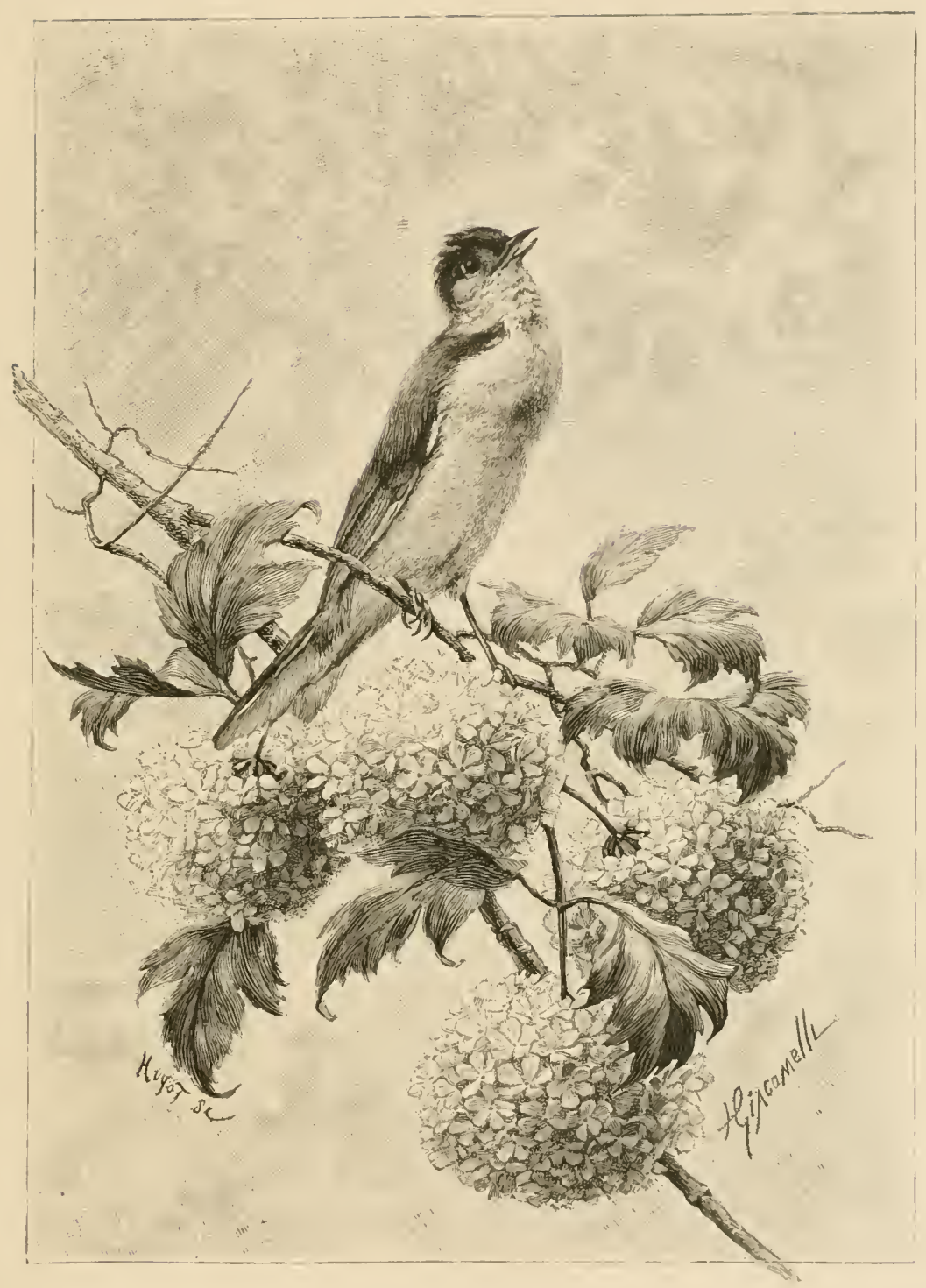

THE WA RBLEI 

to be rocked; whilst the male, perching on a willow branch of clinging to a reed, goes on repeating all day his joyous sprightly song, letting the quick, shrill notes succeed cach other with monied regularity:-cri, cri,

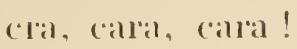

The sun shoots down its rays, and between the reeds the water has the dazzling glare of molten silver; the fiery atmosphere seems to hlaze, and that monotonoms unceasing song harmonizes will the twinkling of the river, the buzzing of the insects and the quavering of the hot air. It is a contimual bahbling, harsh like the voice of a busy honsewife as she comes and goes about the house, giving her orders, scolding her servants and never stopping her chattering. In the district of Brie, in France, they say of a talkative woman, she chatters like a white throat. (Elle jase comme une effarratte.)

This mery warbler has all the domestic virtues of a good housewife, but her faults as well : exclusive, positive and domineering, she wishes ahove all to be mistress in her own house, and will allow no other birds to settle in the place she has chosen. But it is a good-natured bird after all. In the long summer clays, in the gloomy neighbourhood of solitary ponds, it throws out now and then a joyful note. Its song has a rather common melody, it is lively and free, like the merriment of the mob. In spite of its unvaried trite modulations, it is rather original. Whoever has once heard it will never forget it. It 
mingles with the impression left by fine summer days in flowery fields. just as the noisy burden of the belated labourer's song hlends with the louching remembrance of a poetical night in spring.

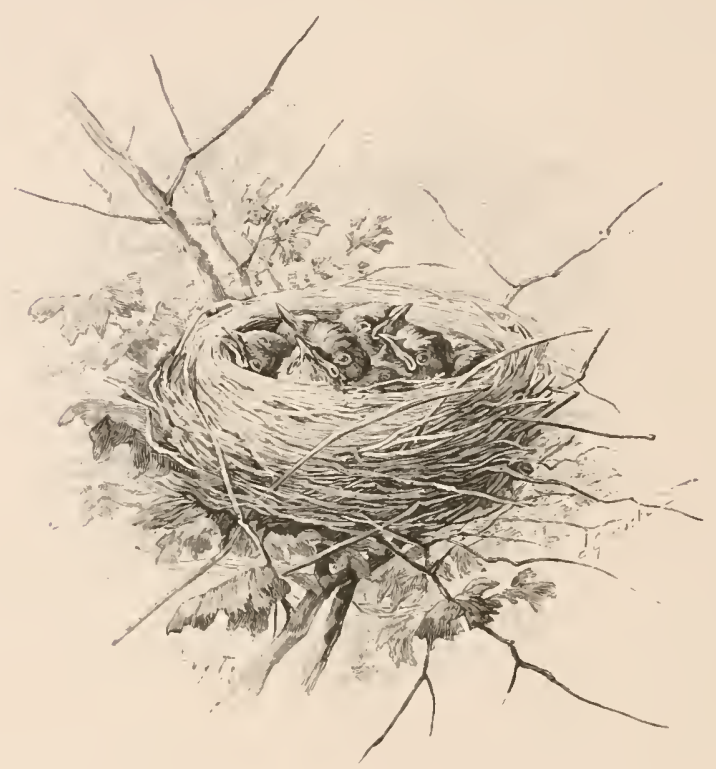




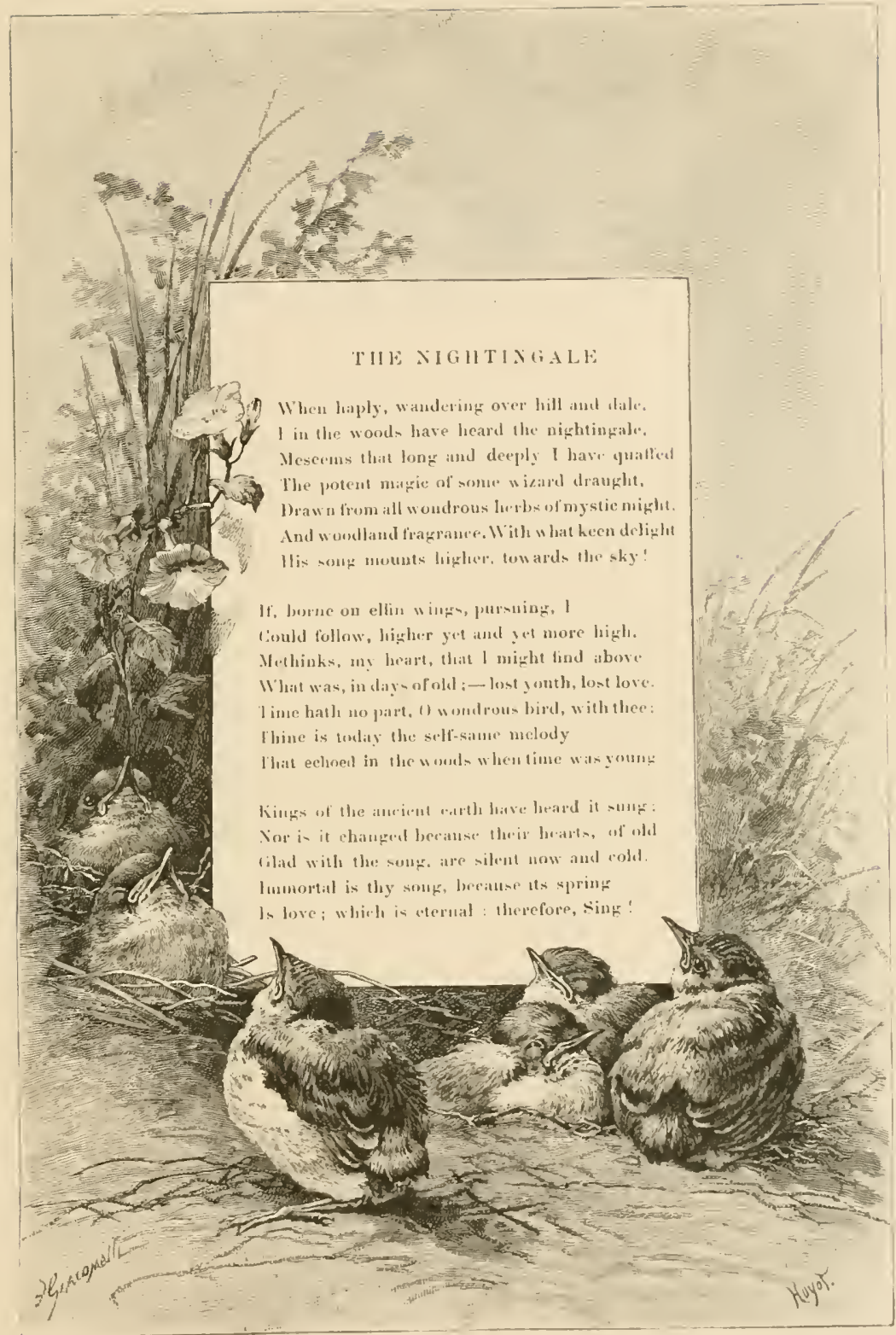





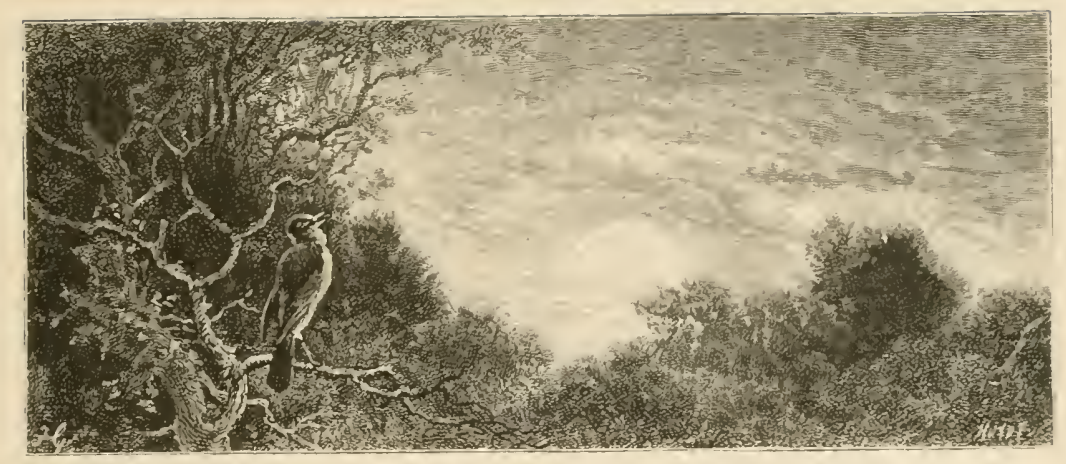

THE NIGHTINGALE

This is the master artist, the rery ling of singing birds. It is small in size, grevish white and reddish brown in garb, it makes no outwall show and ought never to be seen but from the distance. It needs the soft twilight of the moon, the mystery of the leafy forest or the darkness of night; but beneath that more than humble garb is hidden a poet's nature, a most passionate soul, served by a most marvelous instrument.

Already in the sixteentl century did old Belon become almost lyrical in speaking of the nightingale: "When the trees of the forest are covered with green, the 
nightingale for a long while, ceases its song neither by day nor by night. Does there exist a man so deprived of judgment as not to be struck with admiration at hearing such a sweet, loud strain coming out of the throat of such a small wild bird? The lest of the nightingale is that it persists so obstinately in its song, without ever getting. tired or interrupting its strain; it would rather cease to live than cease to sing. ")

It makes its appearance in our gardens and woods at

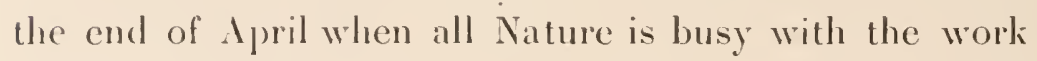
of love and reproduction. Its beautiful song ceases about the middle of June. It comes from the land of the ever fiery sun; there it learned those warm, metallic notes which seem to us the echo of the bright, glowing East. The extent of its voice is surprising, and yet more marvelous is the robust constitution of this frail little bird that can sing on, night after night. Also this artist requires a special food: no seeds, no watery debilitating fruit, but live, and so to say bleeding flesh. It lives exclusively on worms, insects and the larvae of ants. Like most singers it is a great cater, but a great eater of food that is rich in nitrogen. By means of this strengthening nourishment, its museles acquire a wonderful strength and its voice unequalled volume and sound.

It chooses some sonorous glade or some solitary old tree where to give its concert, and twilight or the silent night for the hour of its representation. (Thence its name 
of nightingale : the songster of the night.) Every thing in this bird betrays an arlist's temperament, every thing, even the refined arrangement of its nest, composed outwardly of leaves that are superposed like the petals of a rose, and lined on the inside with long, slender, narrow blades of grass, antistically interwoven. The female nightingale lays three or five shining, greenish brown eggs; while she is performing the office of brooding the male is perched on a neighbouring tree, charming the long lours of her sitting with exquisite melodies.

It is not the performance of a skilful and cold virtuoso, but the passionate hymn of a fiery, voluptuous soul. The Germans, who are apt to be pedantic even in poetry, have tried to transcribe the song of the nightingale and one of their learned ornithologists, M. Bechtein, has made a syllabic notation of it. This is like trying to give and idea of the perfume of the rose by means of a chemical formula. Why attempt to render by insufficient human sounds that divine strain that every one has heard?

This ever varying, masterly melody is truly enchanting. It expresses every emotion: melancholy and joy. tenderness and passion. The song begins with some rapid. thrilling trills; then it changes slowly into a coaxing, tender lullaby, like an appeal to love; then the strain is broken by two deep, grave notes which die away like long sighs; then, again suddenly the tone of the artist changes: brillanti, trills, staccati, sparkling, sonorous 
flourishes, succeed each other rapidly, - and then again they all blend in a dim. dreamy melody. In that original strain. "In shadiest covert hid, "you seem to inhale the perfume of the lity of the valley and of sweet scented forest flowerets, the sap of budding teares, the gushing joy of life in its full bloom.

When I was twenty years old and living in a village, how many nights I passed leaning on the open windowsill, listening to the song of the nightingales dispersed in the bowers! They responded by turns and seemed to vie with each other in cloquence and passion. All around, far and near, the orchards were phunged in mysterious darkness. I listened, charmed, spell-bound, as if I were living in fairy-land. To this ever varying, thrilling melody I would put unconnected words. such as one murmurs in a dream, and I felt myself lifted up, carried away in a magnificent current of poetry.

Even to diay. when I spend the month of May in the country. it happens to me to listen at night to the amomus serenade of the nightingale, trying to recall the emotions and conchantment of by gone days. But alas! youth never enmes back to those to whom it has oncesung it w thong of songs ». Sipring time returns, leaves grow green, nightingales breatle again their serenade in the blooming apple-trees, but other generations enjoy the feast and inlate the balmy breath, the intoxicating liquor of May! It is the same strain and the same fermentation of sap 


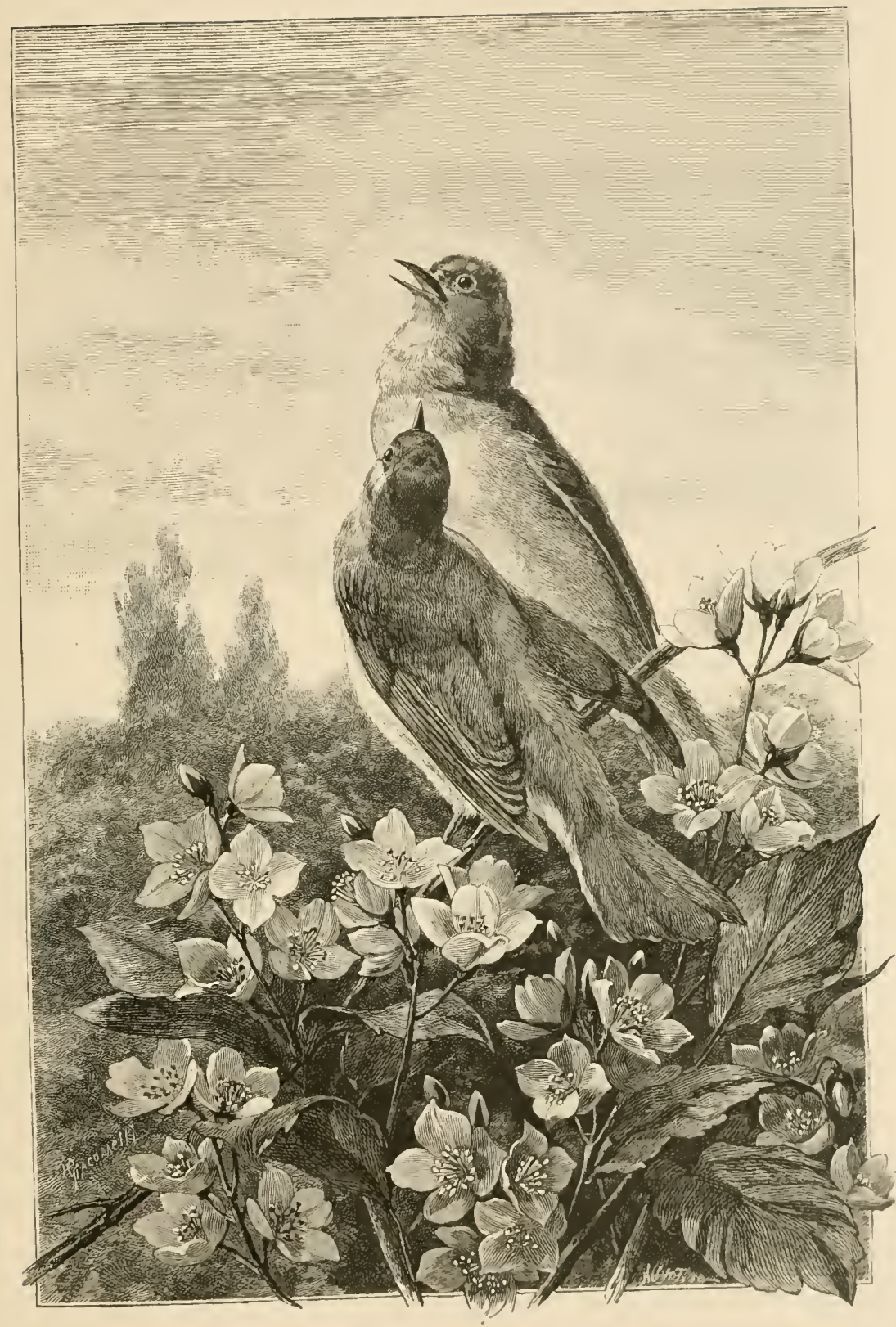

THE NGH'INGAE 

in the forest, but the guests are not the same. Youth has invited other guests to sail in his flower-wreathed boat. Whilst we, the elder ones remain on the banks of the river, tired and disenchanted, the merry skiff sails away, and the chorus of the nightingales which it carries along, grows fainter and fainter as it disappears in the distance.... finally dying completely away in the darkness....

It is not youth that dies away, it is we who disappear; the song of the nightingale is eternal, but where are the birds that sang it twenty years ago? The divine strain itself lasts but a short time every year, hardly two montlıs from Saint-George's to Saint-John's day. After midsummer, the nightingale sings no more. The young are hatched and the cares and preoccupations of material existence put a stop to the poet's inspiration. Their notes are now harsh, being a sort of plaintive jarring, snapping noise: these last sounds seem intended for menace and defiance. The representation is over, the foot lights are put out, the marrelous artist leaves the seene of his trimphs, and carrying his starving brood away with him, he takes his flight towards neighbouring fields and bushes where he will find a more plentiful provision of worms. When you meet him by ehance in antumn, fluttering widly across some solitary footpath, you will scarcely recognize in that silent bied with its livery of a dull brownish grey, the dazzling singer of those 
spell-bound May nights. It is then like those artists so animated and dazzling. apparenty so young and brilliant when seen in the costume of the stage. the dim perspective of the back ground, and the sparkling footlights, and whom you are surprised to find so finded and old-looking. when rou see them leave the theatre, elad in an old over-coat, tramping along pitifully in the mud.

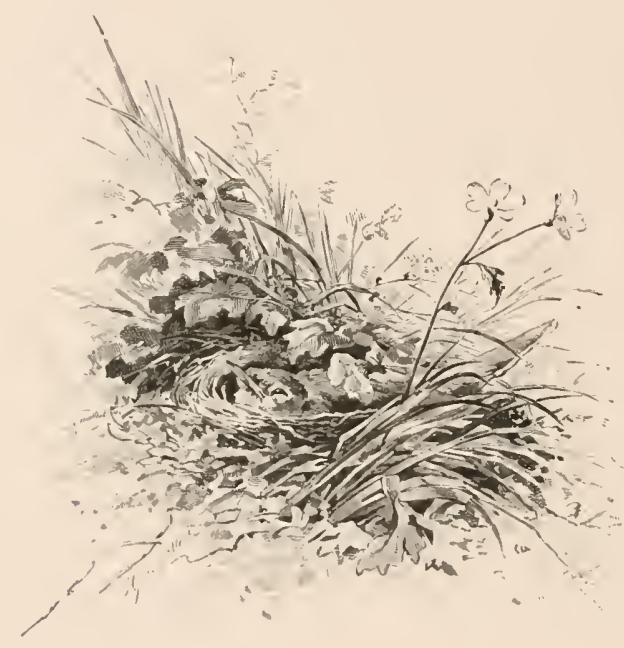




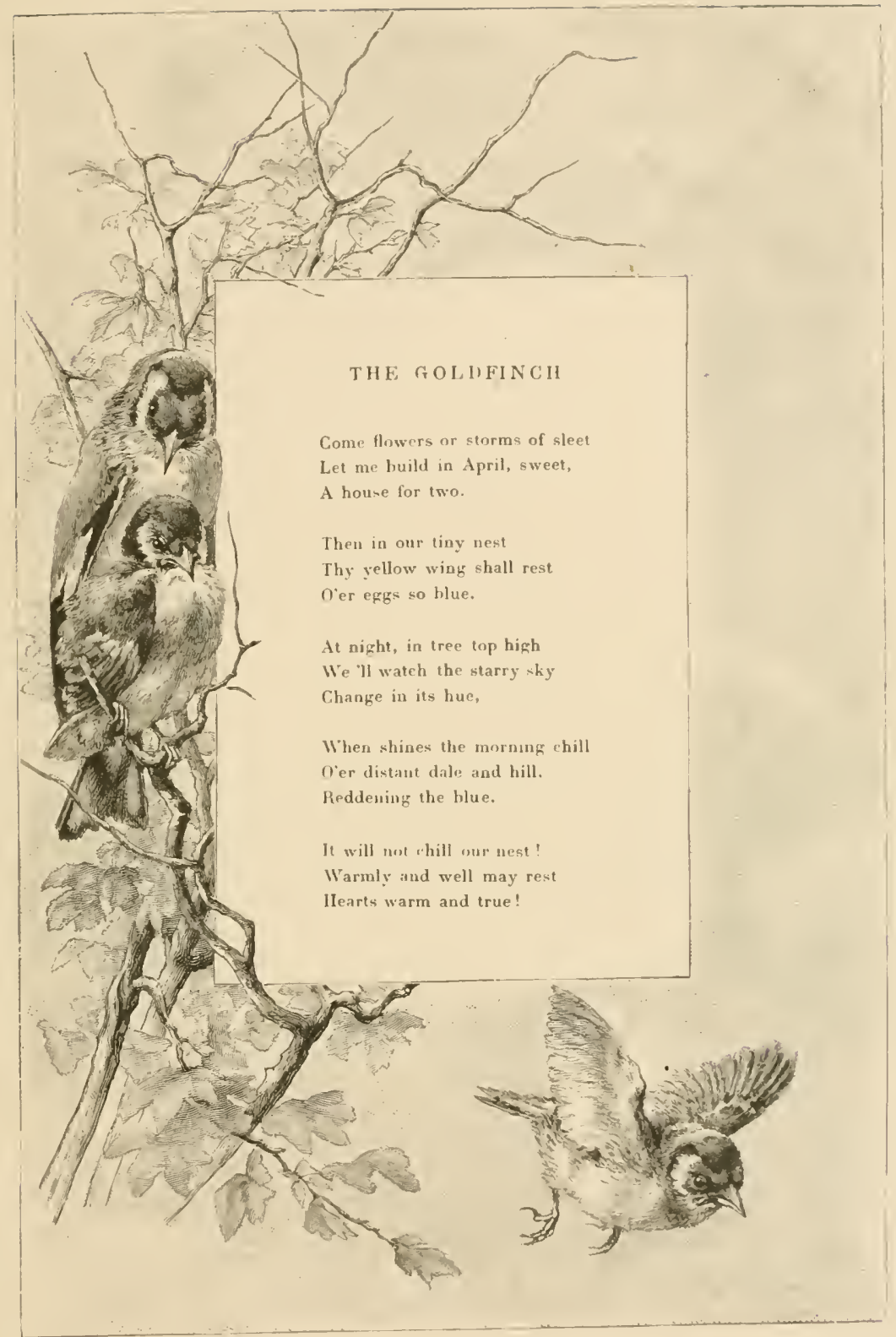





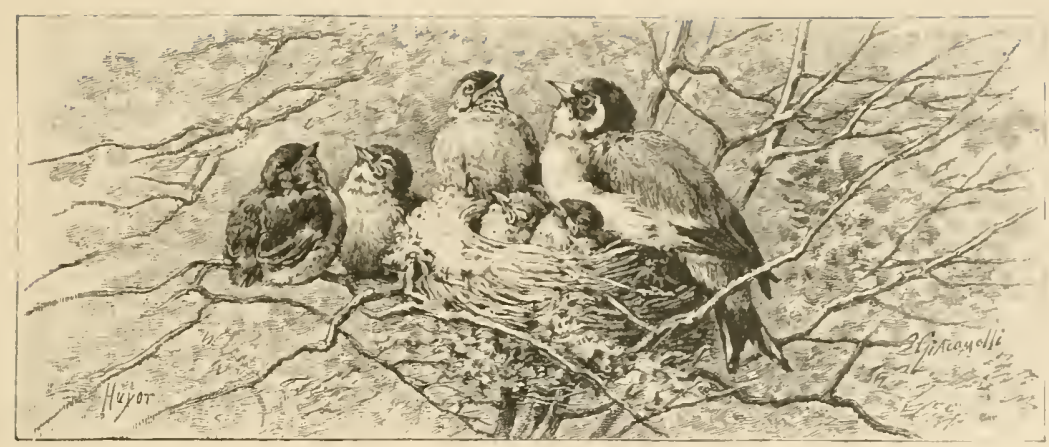

\section{THE GOLDFINCH}

Like the goldhammer, the goldifinch is one of our rare singing birds whose smart costume harmonizes with its melodious, sonorous voice. Old Belon the naturalist says : " it is a bird of finer colour than any other we have in France. ") Its pretty, arch little head is covered with a black hood which is -

1.y joined by a black line to its ivory-coloured neck; the upper part of the face is covered by a sort of crimson velvet mask, through which two arch, dark brown eyes are glistening. Its whitish neck and breast of the same colour, its black wings spotted with gold, its brown back and spolted white tail, 
combine to make it a most impetuous and irresistible charmer.

Chatmaul, jeune, laimant lous les cours apres soi....

Of course I am speaking of the male only; for the plumage of the female is duller and her habits mose pearelul. she is the type of a housewife who hoves her home, and she hardly ever leares her carefully interwoven nest. 'This nest is at the same time solid and comblortable; outside, it is made of fine moss, lichen and thistle burrs, the whole interworen with small roots; inside, it is like a soft elastic cushion made of hair, dry grass, feathers and wool. Goldfinches like to suspend their nests on to the most flexible bough of linit trees, so that the slightest breeze swings their aerial lome gently to and fro. Sometimes, howerer, they build their nests on more steady sround, such as the hollow of a bush or the heart of a clump of green.

Last spring, I found two such nests built close together in the entangled boughs of some ivy covering an old garden wall. Each nest contained seven young ones, - seven greedy mouths which opened wide as soon as you put aside the iry leares. The two fimilies secmed to be intimitely united. 'Towarls erening, Ho males would come together on a neighlooming lawm, smooth. ing their feathers and wathling llowe song with fuaint motions of the head, just as respectable towns'people 
come together at nightfall after the day's work, in order to have a little gossip while enjoying the cool of the evening on their doorsteps. Meanwhile, the busy females were fluttering to and fro in search of flies and small worms for the supper of their large family.

One day it happened that the eat of the family, which had hidden treacherously behind a clump of lilac trees, took one of the mothers by surprise as she was leaving her nest, and strangled her. I then witnessed a most touching scene, which proves that charity is not exclusively a human virtue, and that it can dwell eren in the heart of an humble goldfinch. The surviving mother adopted the children of the dead bird. She undertook to feed the two hroods, and during a whole week, I used to see her flying from one nest to the other, dividing the food between her seven little ones and the seven orphans.

The female goldfinch is an honest, valiant creature; she is the very embodiment of self-denial and derotion; she shows a most exemplary attachment to her young ones; the sun may shine or the clouds burst in cold hail showers, she remains sitting on her nest with ontspread wings, and sometimes after a storm, the hail has bruised her while she was faithfully attending to her tender brood.

Too line to work, the male goldfinch, meanwhile, searcely helps her in her task; he sometimes bends ovel 
the nest which eontains the young ones and beguiles his faithful mate with the varied modulations of his cleat song, his free and tender strain. 'This song consists in two stroplies, or rather in a prolude and a cavatina, which are separately executed at longer or shorter intervals. The melodious "avitina is set off and enlivened by brilliant flomrishes, in which one ran distinguish Horee rharacteristic notes: Finch! Finch! Finch ! which come back ever and anon like a roll-call. The male is very proud of his musical talent, just as he is intensely rain of his bright colours and brilliant plumage. Ife probably thinks that his beauty cxcuses him from bencaning himself with vulgar household cares, and he whiles away his time in self-indulgence, selfishness and voluptuous idleness.

When the young ones are fledged and feathered and strong enough to fly. the whole lamily takes its flight to the ficlds. The golulfinch is a high liver, an epicure, fond of choice and saroury seeds. In French this bird is called chardmmeret, that is, a lover of thistles, but in spite of its name, it does not care for thistles, at least not until cold weather sets in; then it is often obliged to be content with such meagre fare. In autumn, these pretty birds stirt off in flockis and go marauding about poppy and rape ficlds. Of a very quarrelsome disposition, they often hiove a fight with linnels, who haunt the same parts, but the goldfinches are generally victorious; howerer, they also meet titmice and these birds, with 


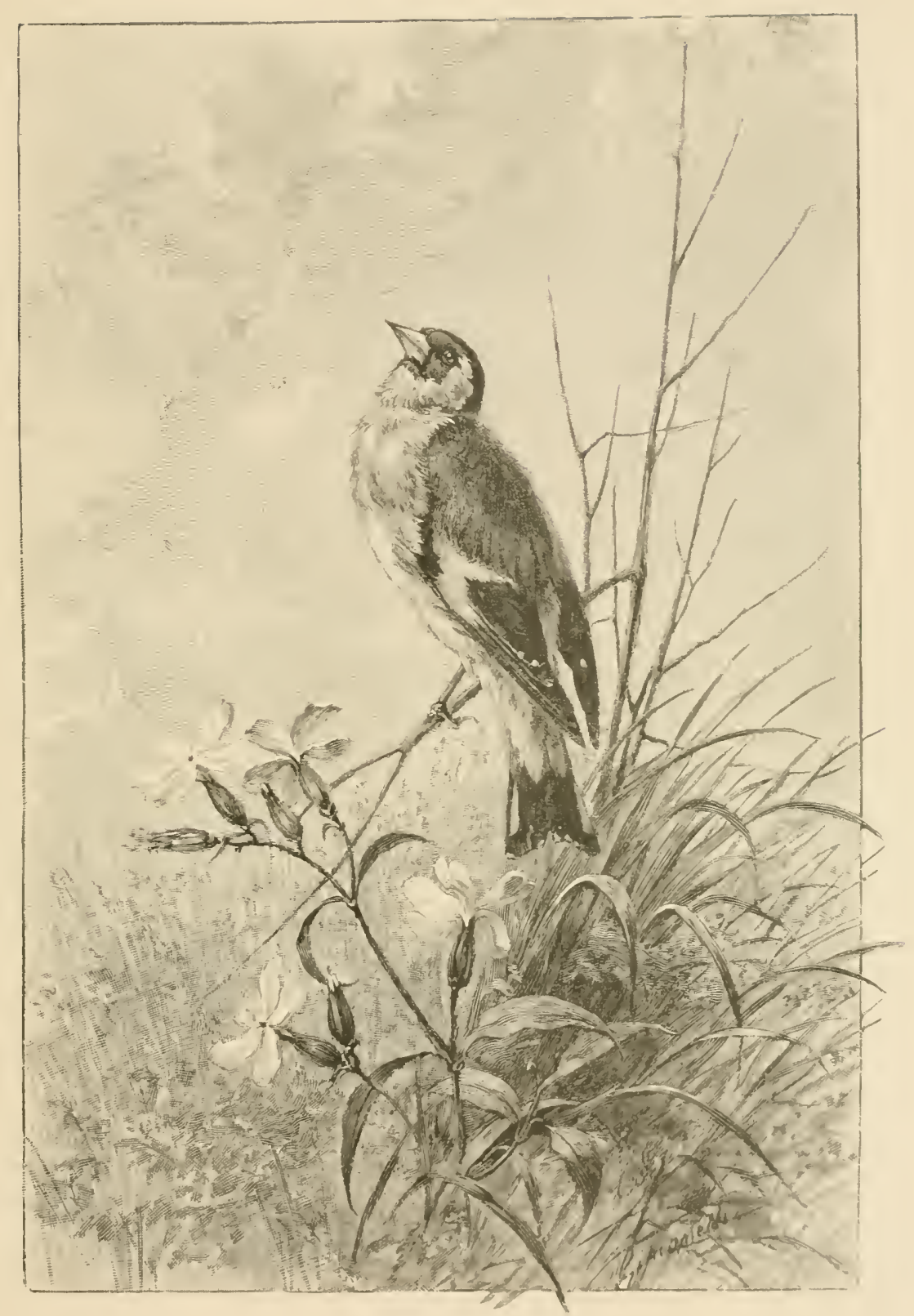

THE (:OL,DFINCH 

their sharp pointed bills, are sure to be most formidable adversaries. who cruelly and completely avenge the linnets. Turbulent and heedless, Hying low and close to the ground, goldfinches are easily inveigled into the snares that men, and especially chitdren, set for them. Beware! then comes the cage and the humiliating labour of captivity!

The brilliant plumage of the goldfinch makes him a precious prey for bird-catchers. Proud of his fine appearance, and having the tastes of a high liver, he cnds his career like those pretty fellows who exchange their beauty and porerty for the servitude of a rich marriage. When it is once shut up in its "age, the goldfinch will always find its table spread with an abundant supply of millet and hempseed, but it has to pay for this delicate fare by servile manœurres. It is taught to fire a gun and to feign death; it is obliged to bear straps and to carry small pails of water for filling its bath.

But these are only some of the steps on the road to slatvery, the first, the easiest to climb. Not only is the brilliant goldfinch obliged to earn his dimner by hard linbour, but he is obliged to degrade himself by making love to a chattering, intemperate canary-hen. Ile becomes the father of mongrels, called canary-goldfinches, whose hybrid plumage is odious to his sight. Then, as a last mortification, the regimen of the prison tones down the 
colours and tarnishes that lustre of that brilliant garb of which he was so proud. His beautiful crimson mask takes an ugly sandy hue, and the bright golden spots on his wings grow dull. The beautiful, lively, merry bird grows coarse looking and vulgar, and if by chance a wild dipper goldfinch, proud of his freedom, passes near the cage where the poor prisoner is captive, he hardly recognises a friend and lorother in the dull, coarse-looking, illmated bird, who has lost his golden spots behind his grating and who works like a galley-slave, piteous to behold, in the company of a jealous and peerish canary-hen.

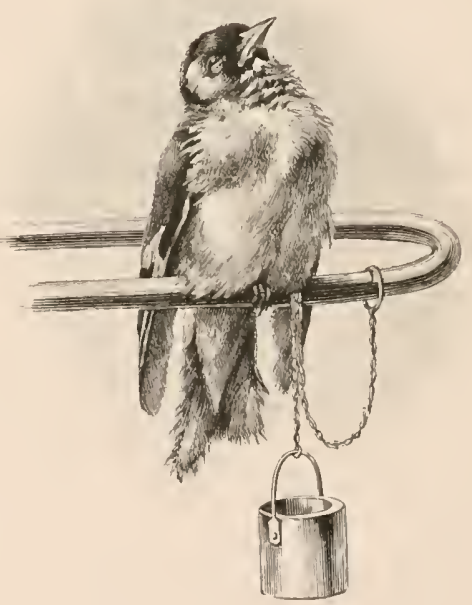




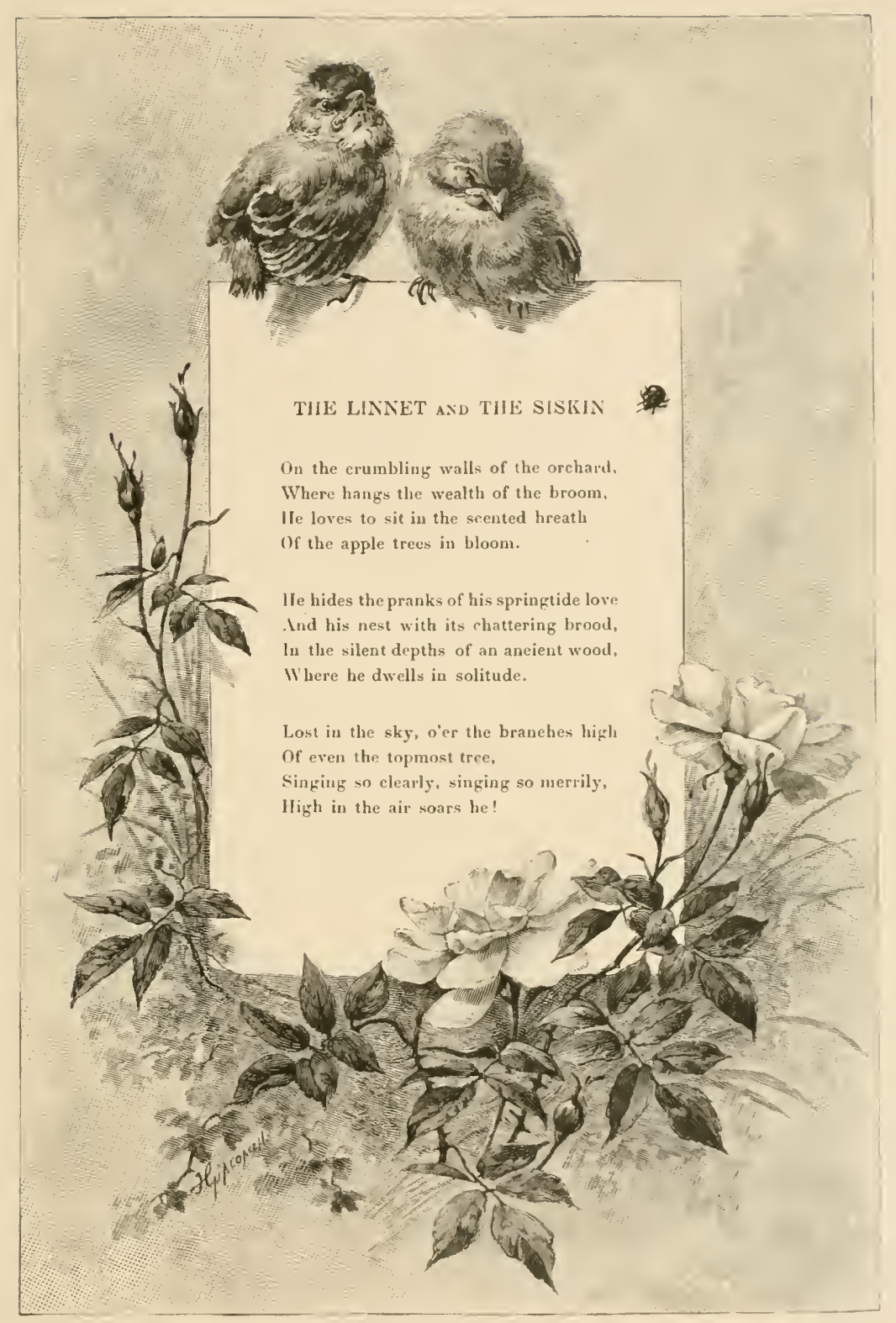





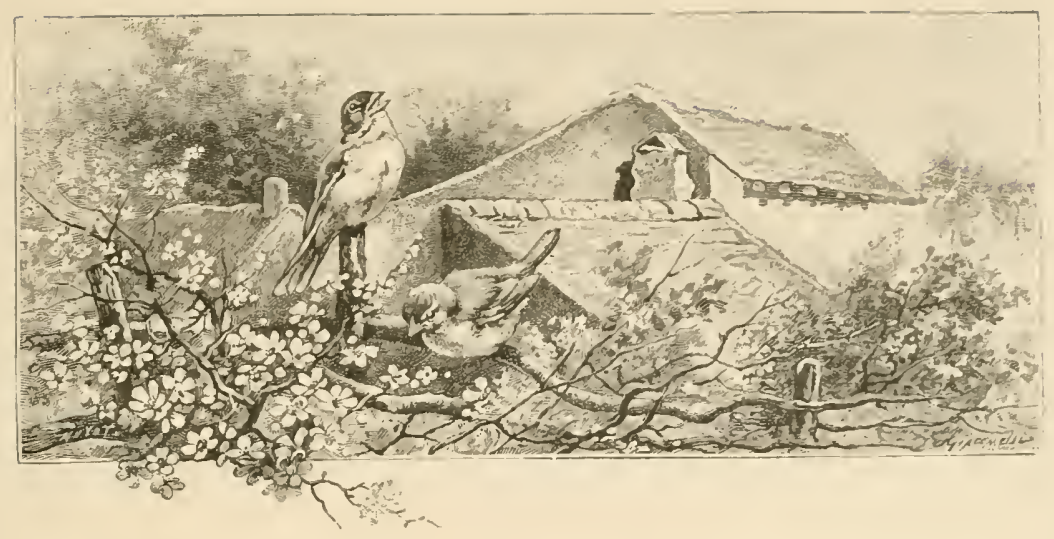

\section{THE LINNET AND THE SISKIN}

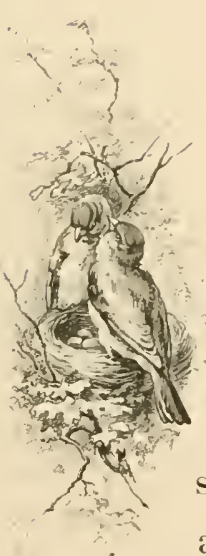

Both these birds are great secd-eaters. Although their habits and origin are distinct, it is difficult to speak of them separately, for they resemble each other in many ways as regards disposition and mode of existence. They are both pleasing songsters, merry companions; their temper is docile and easy, and they can be tamed with ficility.

These amiable qualities are sure to make them more easily the prey of man, that false fricnd who loves birds only to put them into a cage in order to speculate on them.

The linnet, which is rery common in our parts, is more 
settled and homely in its habits than the siskin. In liberty in the woods its plumage is bright and pleasing. Its head and chest are of a fine red colour, its back is chestnut brown, its stomach reddish white, its wings and the feathers of its tail black, spotted with white. It is smaller in size than the goldfinch, and its bill is sharper. When it is shut up in a cage, like that bird it loses its liveliness and the oddhess of its colours. The male, in a cage, soon gets to look like the female. The bright tints of its plumage facte insensibly; its garb turns brownish grey spotted with rusty dots - a vulgar and sad livery of bondage.

These birds chose their mates and build their nest in May. In wine countries they often huild their nest among the vines on the vinepoles; in the neighbourhood of forests they cloose thickets of young fir trees, and when one crosses such a wood in the time of pairing, one is sure to hear on all sides the song of linnets that are busily suspending their delicate dwellings on to the boughs of fir trees. The nest consists of small leaves, roots and moss on the outside, inside of feathers, hair and plenty of wool. On this soft bed the female lays six bluish white eggs, spotted with nut-brown at the broader end. When the young are grown enough to take their flight the whole houseful takes wing together; the whole clan of linnets congregrates and starts off to explore the orchards and groves of the neighbourhood. 
In spite of the approach of the bad season the flock does not separate. All winter long the numerous families of linnets continue to live sociably. They glean some scattered thistle-seed along the by-paths, perching on poplars and lime trees, picking the young buds; you can hear them twittering in the boughs as soon as the February sun sends some warm beams through the winter fogrs. The males only are fine musicians. They begin with a light prelude which however is original only with wild linnets. The captive birds repeat only those strains that have been drilled into them; they are artists of inferior quality.

M. Gueneau de Montbeillard remarks a little sententiously that this is quite natural. "The bird whose voice has been formed in liberty, following only inner emotions, must have more touching accents than that which sings without an aim, only to kill time or to exeresse its organs»).

The truth is that the art of song does not develop itself spontancously even in singing-birds, but only by education and imitation. In the free state the young linnet forms its voice by hearing its father and other males of the neighbourhood repeat the old traditional melodies, which have been transmitted from one generation to another. The linnets that are born in a eage, or in the nest prepared by a bird-catcher, have often no other instructor than some boor who whistles some popular 
song for their henefit. These music lessons generally take place in the crening. Somelimes the bird-atchere, in order to excite the linnets to sing. lakes them on his finger and holds them up in front of a mirror. where they imagine seeing a bird of their own species. While the master is whistling his dity, they think that they hear their unknown companion; this illusion makes them girldy, and finally thry all join in the chorus. It is a sad somg of captivity without savour or perfune. and is no more like the pretly song of the wild linnet than the sickly lily of the valley raised in a hothouse can be compared to the vigorotis bilmy lily of the woods!

One would think that the slim and lively siskin with its olive-green plumage linted with lemon colous. born in liberly and fond of long travels, would have a more independent character than the limet. But this is a mere illusion. The siskin is like certain gypsies whose ragrant tastes do not exclude a certain fondness for servility. Although it bears a slight resemblanee to the titmouse on account of its skill in climbing and in pieking seed, yet it has not the undisciplined disposition of that valiant little bird.

It is said that in the free state they build their nests on the islands of the Rhine, in the Vosges mountains, in Hungaria, especially in woody, mountainous regions; but it is very difficult to find these nests. The hirds hide them so skilfully in a litter of verdure, that they are said 


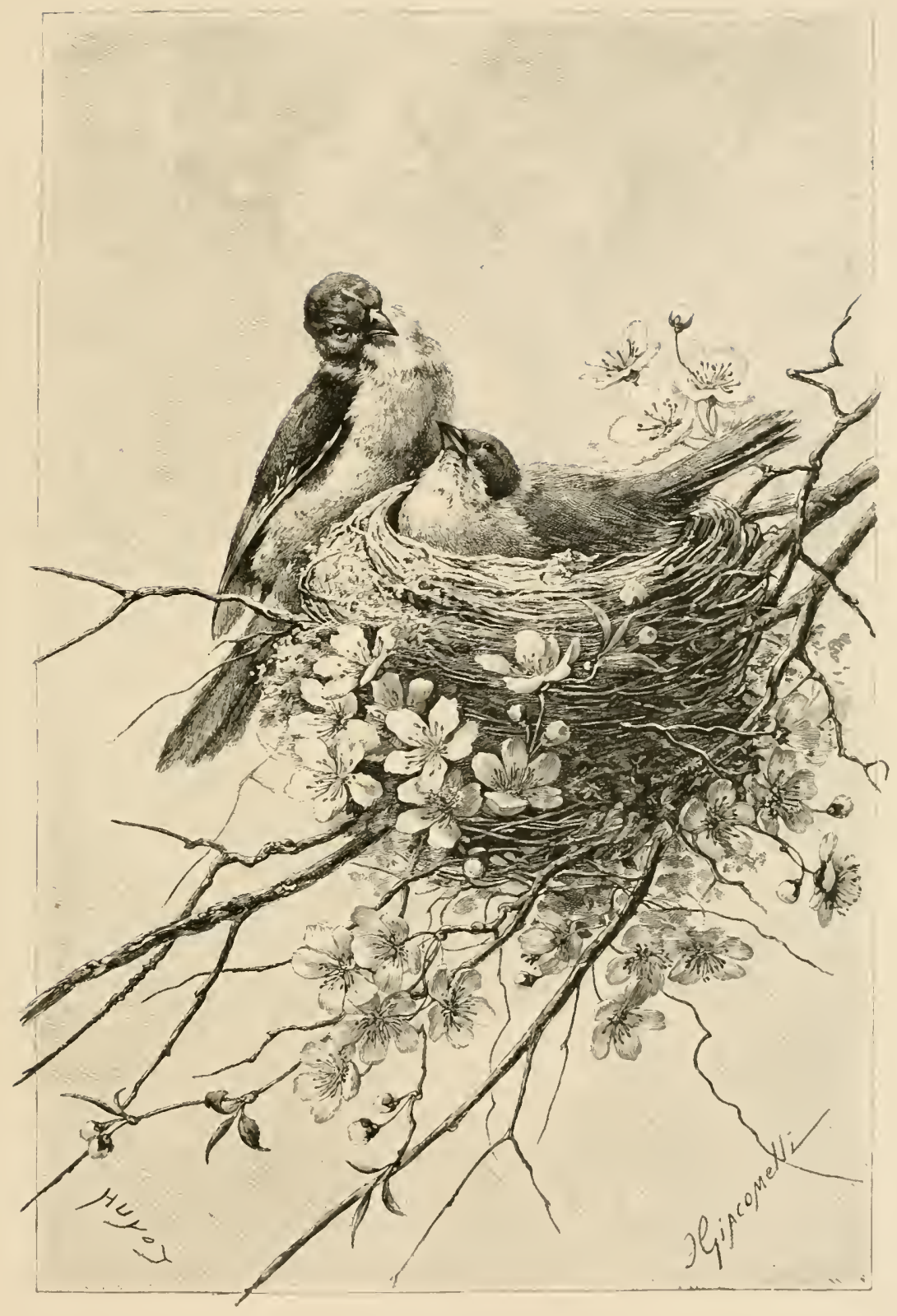

LINETS 

to render them invisible by depositing in them a magic stone. They hide when they are pairing: their wooing is carried on mysterionsly, so that nothing precise is known about the laying of their eggs. Being birds of passage, they come to our country at harvest time and select for their dwelling the banks of a river where alder trees grow, being very fond of that seed. As soon as cold weather sets in, they emigrate and do not return to France until orohards are in full bloom; they are particularly fond of apple tree blossoms.

The flight of the siskin is rapid and high; but it is as impetuous and simple minded as the linnet, and is easily caught in the grossest snares. A cage containing a captive siskin, serves as a decoy-bird; some lime-twigs set into the soil are sufficient to attract the griddy unsuspicious wayfarer. Then adieu to freedom: he will never see again the Vosges of Lorraine, nor his mysterious retreat in the heart of some fresh, green alder-grove.

In the aviary he will meet some other seed-eating birds, such as linnets and gol Ifinches, and like them, he will have to submit to the apprenticeship of bondage. Luckily his natual disposition is as docile as theirs and he gets easily accustomed to his new existence. Being provided with board and lodging, fresh water in his trough. and plenty of seed in his manger, he earres little about the rest. After a short time he will no longer regret the joyous ragrancy of open air life. 
50

THE LINNET AND THE SISKIN

He even forgets to make love and if perchance he pairs with a canary, the ill-matched marriage generally remains barren, and the eggs when hatched are found to be empty. The siskin loses its faculty of reproduction in bondage, and also like the linnet and the goldfinch its bright tinted plumage.

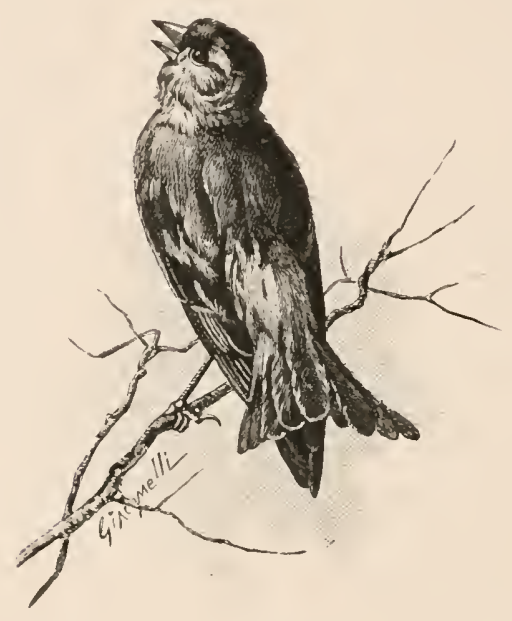




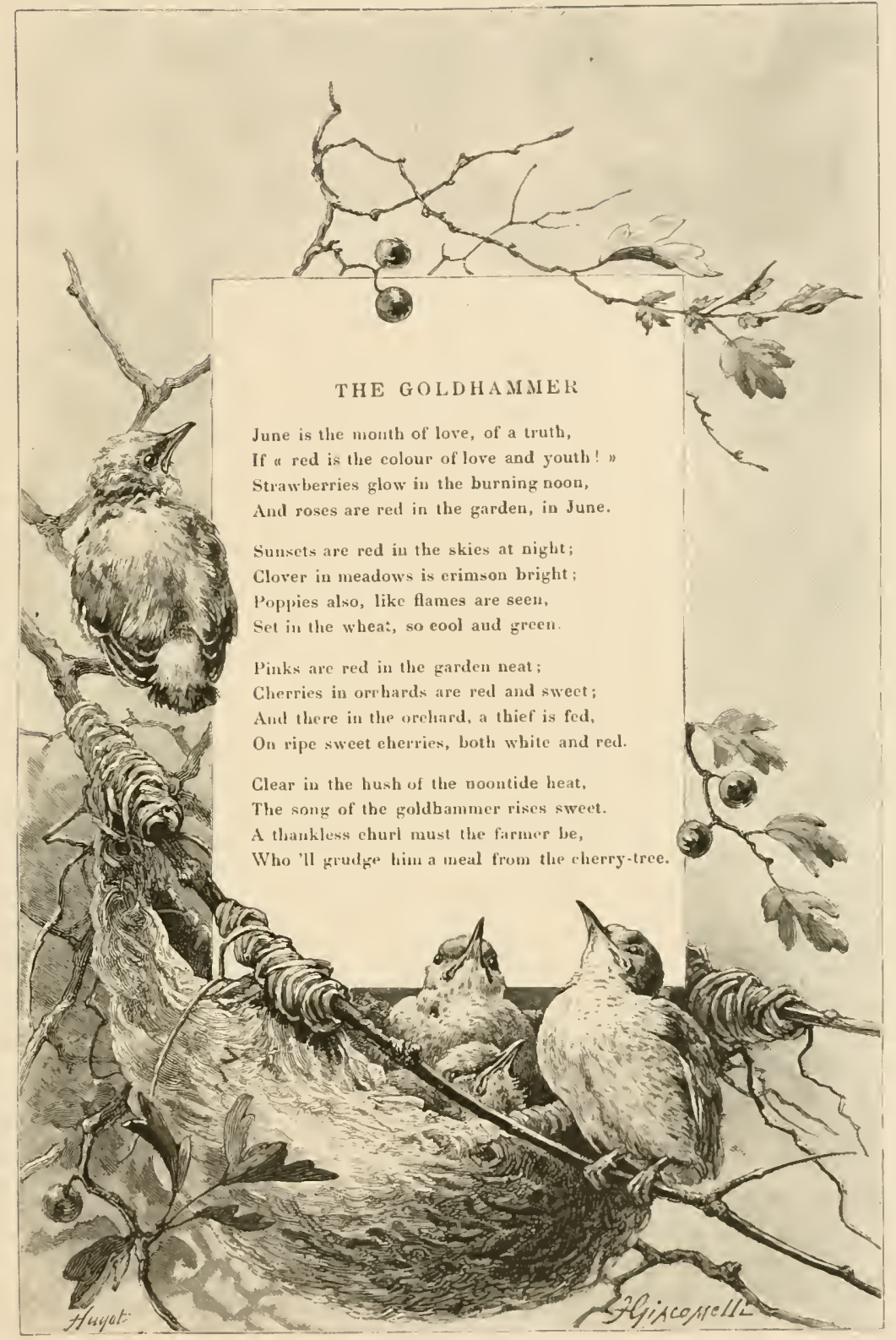





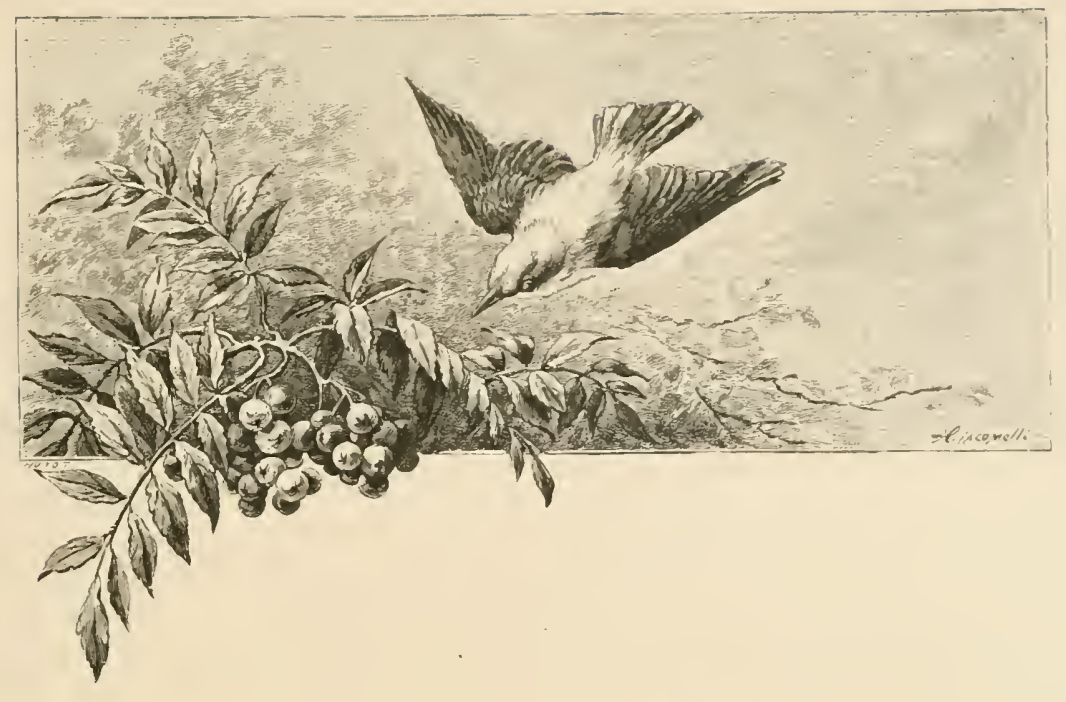

THE GOLDHAMMER

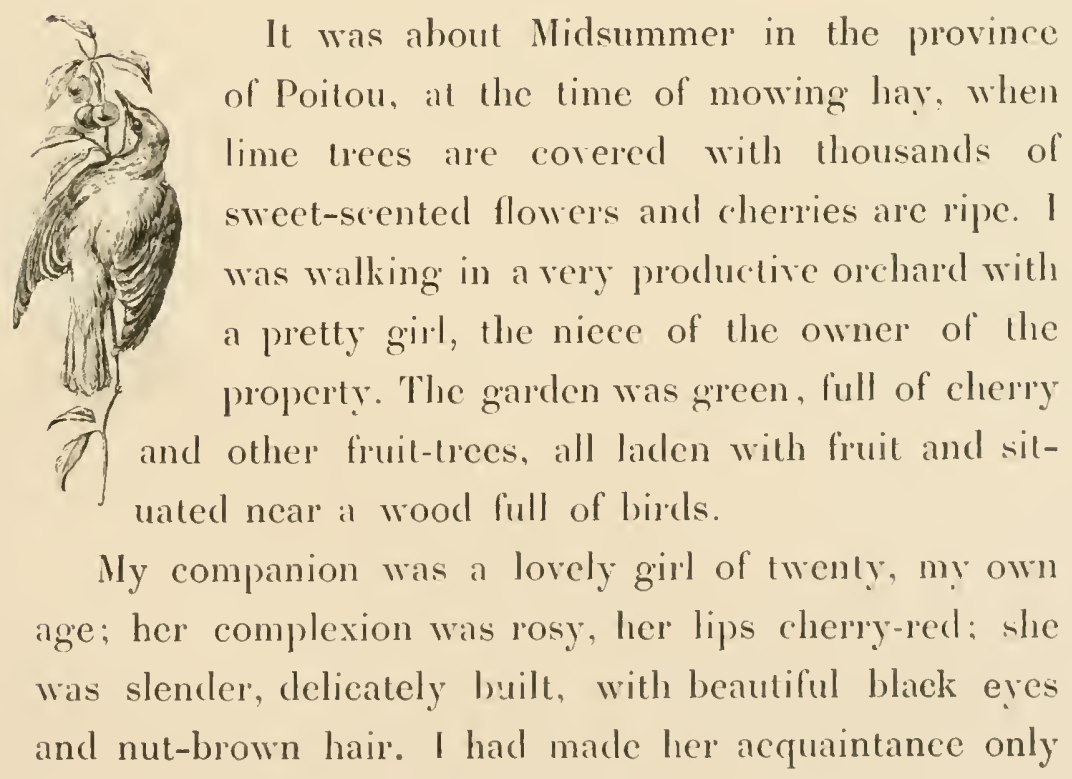


the day before, but in the country and especially in July, one grows soon intimate. The fresh morningair, the bright sunshine, the delicious seent of new mown hay which came from the meadows set us yet more at ease, and we were walking under the trees in the garden chattering like a couple of old friends. She was of a merry disposition, very inquisitive and talkative; I rather timid and of a more romantic mood, easily inflamed and concealing under very awkward manners a latent tenderness which only demanded an opportunity to show itself more openly

While we were loitering about, the song of a bird in the bowers struck our ear - a song consisting of short phrases, bul of an exquisitely mellow sound. We could only compare it to the notes of a golden flute. It was a pure and full sound, wavering and yet tender at the same time.

The young girl stopped to listen.

"What bird is that singing so prettily? " asked she.

"It is a goldhammer."

"Really, what is it lilie? I have never seen one."

She made me describe to her the bird that was so fond of cherries. I tried to picture its beautiful yellow breast with its black wings: its half black and half yellow tail. I tried to give her an idea of the goldhammer, with its broad, wide open, purple-hued bill, its open nostrils, its large, round, dewy eye, red as a heart-cherry 
and moist as if it were bathed in dew, bewitching and irresistible; its slight black mustachio which gave such a piquant expression to its epicurian face. I told my companion that these birds come to us in the season when red and white heart-cherries take colour, and that they build their nest in the place where the highest boughs branch off. They line their nests delicately with soft grass and spider-webs, they suspend them like a hammock between two boughs by some supple but firm ligatures which swing the nest to and fro at the slightest breeze, thus adding a yet more voluptuous pleasure to the comfort of their aerial dwelling.

"Cherry-juice predisposes to tenderness » I continued, " and when the goldhammer has got drunk on wild cherries and on heart-cherries, he makes love to his sweetheart in his softly swinging nest. "

My pretty companion laughed at this remark and said that she should very much like to see a goldhammer.

I replied that it is not an easy matter, for the greedy bird has a very distrustful disposition and is rather unapproachable. I told her however that we might try.

We walked very stealthily hand in hand over the thick grass, taking great precaution not to startle the hird in the cherry-tree, and we drew near the large tree from which the melodious, flute-like notes issued. We had 
hardly reached the foot of the tree when the shy wild bird took wing, but we managed to perceive between the leaves its slender, well built body and its black and yellow wings, which were fluttering as it took its flight towards the wood.

We had remained some time near the cherry-tree, stretching our necks, hand in hand, raising our eyes to the bowers above us where the ripe fruit was shining between the leaves. They were red and white heart-cherries with fleshy pulp and inviting colour. A ladder just happened to be standing against the tree.

"Let us go and take the place of the goldhammer ». she suggested, letting go my hand.

Pulling her skirts together, she lightly ascended the steps of the ladder, and from the foot of the tree I could distinguish in the shade her small feet half hidden under her striped pink dress. Half-way up the ladder, she turned around and said with an arch smile :

"Well! are you not coming?"

Of course I wished to come, but I should never have dared to do so without being invited. I followed her however blushing, and we both soon found ourselves in the heart of the tree.

The position was very pleasant. although not very confortable; at the slightest movement we made, her arm and her hair would touch my cheek, but she was laughing, while I was looking very much constrained 


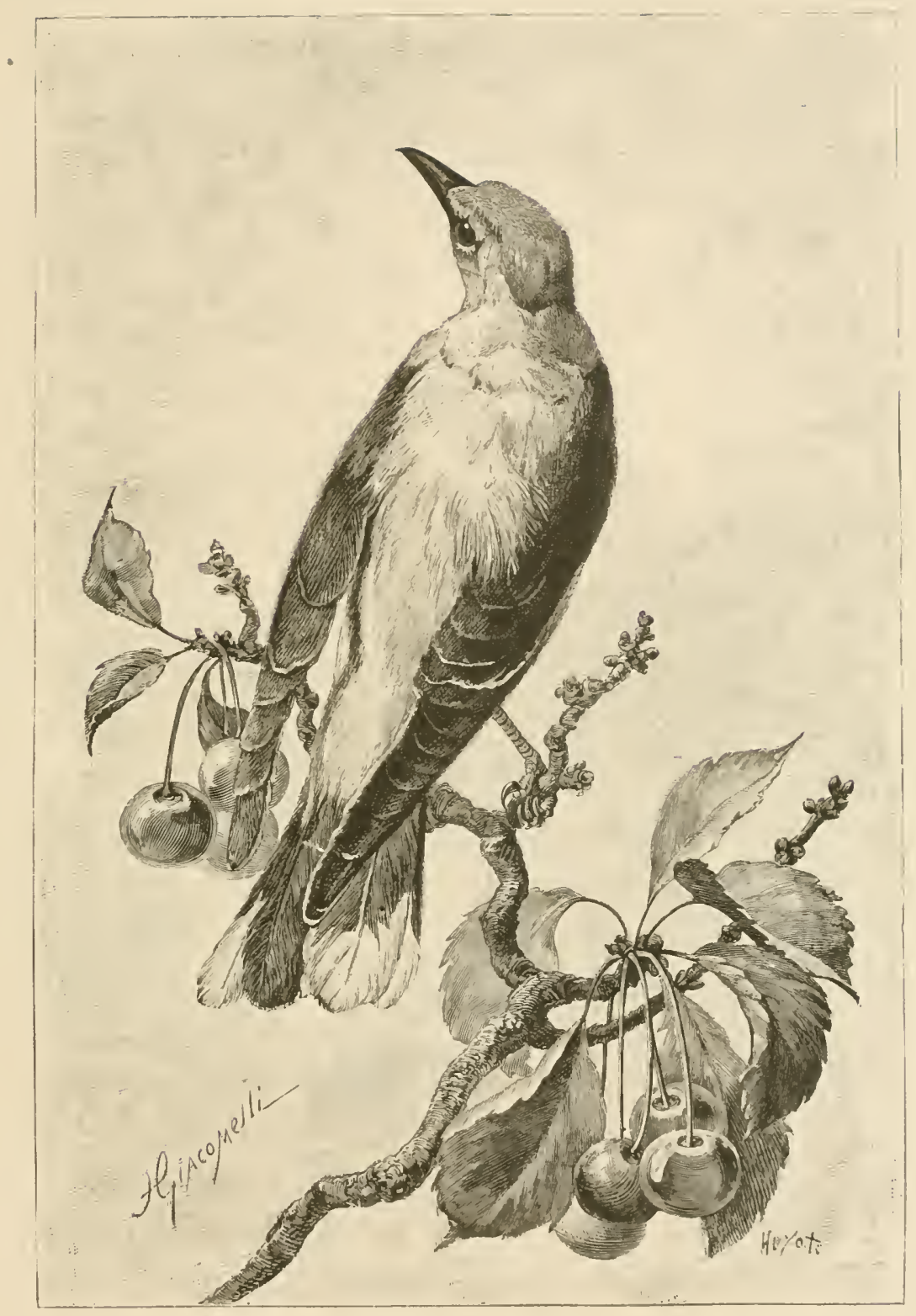

THE GOLDHA II IER 

and very foolish. At last she caught hold of the trunk of the tree, swinging herself on one of the horizontal boughs, sat on it as if she were on horseback. I did the same thing, and then we were sitting near each other, softly rocked to and fro on the elastic and flexible bough; only I had no comfortable prop to lean against, as she had, or rather my only prop would have been her waist and shoulders, and I was too stupidly timid to make use of it.

How I then envied the lightness and dexterity of the cherry-eating goldhammer! That epicurian bird knows how to poise himself on a bough, and that unsteady position between earth and sky neither prevents him from satisfying his greediness nor from making love to his sweetheart. Even when the wind shakes the tree, he swings with the foliage and loses neither his appetite nor his presence of mind.

I could not say the same of myself and in spite of the tempting company of my pretty neighbour, I was ill at ease and more embarrassed than before. She did not seem to notice it and went on merrily picking the cherries within reach of her hand and lips.

" It is very pleasant up here, do'nt you think so, said she; we are like the goldhammer and his sweetheart in their swinging nest. ”

Did she wish me to imitate the goldhammer yet more completely? I was too stupid to understand her; besides 
60

THE GOLDHAMMER

it was as much as I could do to keep myself poised on the branch; a few minutes after I made a false movement and fell stupidly down at the fool of the tree.

She burst out laughing - a short nervous laugh and after having stuffed her pockets with cherries, she too came down.

I was furious at myself, and we took our way homewards in almost perfect silence, ill-humoured; while on the outskirts of the wood the goldhammer was whistling his song as if he were laughing at my silliness. 


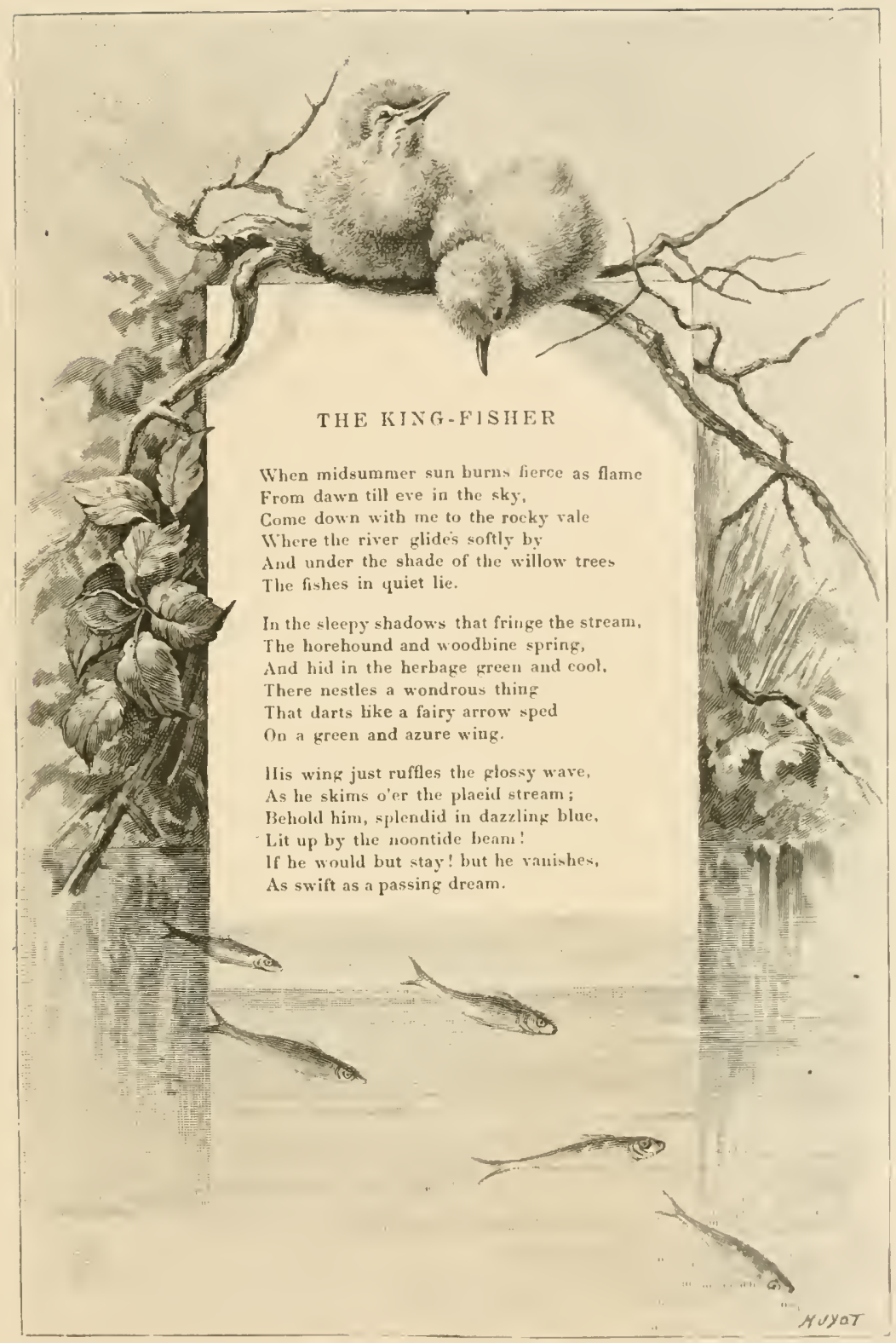





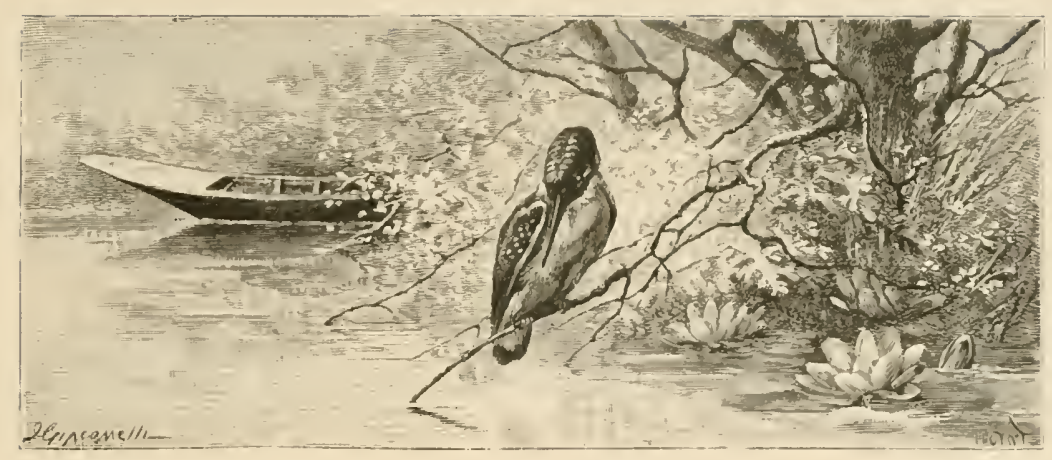

THE KING-FISHER

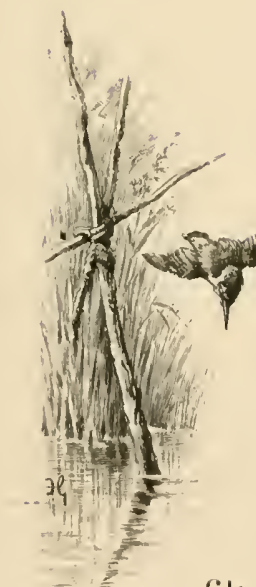

During hot July days, I often recall to my mind a certain wooded pass in the forest of Auberive, where the Aube, yet near its source, opens its way between steep crags under the shade of hazel-nut, ash trees, and beeches. The branches are inextricably interworen above the little river, so that it is almost dark there in broad daylight. A phosphorescent light filters through the dense foliage, and on the black soil - slimy alluvia - those plants abound that are usually found in damp places; rows of purple willows stand close together on the banks; the woodbine 
dips the fine feathered sprigs of its flesh-coloured tufts into the current: almond-scented meadow-sweet perfumes the air, whilst the dark red fruit of the wild raspberry bushes gleam in the darkness.

I used to scramble into the pass by letting myself down an almost impracticable path, fit only for goats, creeping like a cat under bowers of entangled brambles. In the hot hours of the afternoon I used to delight in this solitude and freshness. The dark river was murmuring softly; now and then, some small bright drops would rain down from the overhanging branches and ripple the surface of the water. It was there that I made the acquaintance of the king-fisher.

The one that haunted that peaceful retreat had probably built its nest in the neighbourhood, in the lurking hole of some fresh-water crab, for I often saw it shoot like an arrow over the current. It used to graze the water with a plaintive ery and then disappear suddenly. I had hardly time to admire its back and its greenish blue tail, its wings and head covered with turquoise-coloured spots, its fiery-red breast and chest. It first, my presence used to disturb the wild, shy bird; but after a while, my discreet and peaceful mood would make it more confident, and it would finally circulate under the bushes, without heeding me any more than if I had been the trunk of a tree. I would often perceive it in the green, dim twilight of the sleeping river, perched motionless on a hiazel-nut 
bough overhanging the current, its colours gleaming in the shade like those of some strange jewel set with sapphires, rubies and emeralds.

There it would perch for hours, with fixed gaze and bent head, watching for the passage of some small fry. Suddenly it let itself drop straight down into the transparent water; then it would reappear with some minnow or stickle-back in its bill, flying towards its hidden nest. It happened sometimes that after having dipped several times, it reappeared with nothing in its bill; it would then fly up the current, uttering a low plaintive cry and disappear again in search of some nook more abounding in fish.

Why are river birds almost always sad? The heron. the curlew, the snipe are melancholy birds; even the white wag-tail, with its everlasting motion on the gravel backwards and forwards, looks like a heartsick creature. Is their sadness caused by the influence of their haunts? Large ponds bordered with willows and reeds, in which the wind whistles, morning and evening mists, the murmur of hidden forest springs, all these incite man 10 melancholy; do they act in the same manner on the nervous system of birds? One is inclined to believe so. However, for the king-fisher as well as for the heron, there is a more prosaic reason for their pecvish disposition : the uncertainty of their daily subsistence, the anxiety with which these birds have to watch for their 
prey for hours at the same spot, are surely enough to account for it. When one's stomach is empty and one has to kick one's heels till some problematic fish comes into reach of one's bill, one is not inclined to be fonlishly merry. Even those who follow this oceupation tor pleasure and are sure of finding a good supper when they come home, contract the habit of nervous melancholy in the long hours of watching. Nearly all anglers are predisposed to hypochondria.

The king-fisher spends its life in an often deceptive quest after food, in a painful struggle for existence. It has hardly time to think of love. Its nuptials are of very short dumation : it builds its nest hastily, deposits six or seven white eggs, and as soon as the young are hatched it lakes wing again in sourch of its daily subsistence. In the fine season, such a life is bearable, but when the winter is severe and streams are frozen, it is obliged to beat a long time along the banks of the river before it finds its prey, and more than once it drops down starved on the frozen river.

This wild and noble-looking bird is a restless rover, a lover of solitary strands and shady retreats; he looks like an exiled prince who has been changed into an animal by some evil fairy. The Grecks belicved him to be Alcyone, the daughter of Eolus, that had been metamorphosed into a bird. In our own time the king-fisher is still the object of vague superstition in some rural districts. Is the country-people 


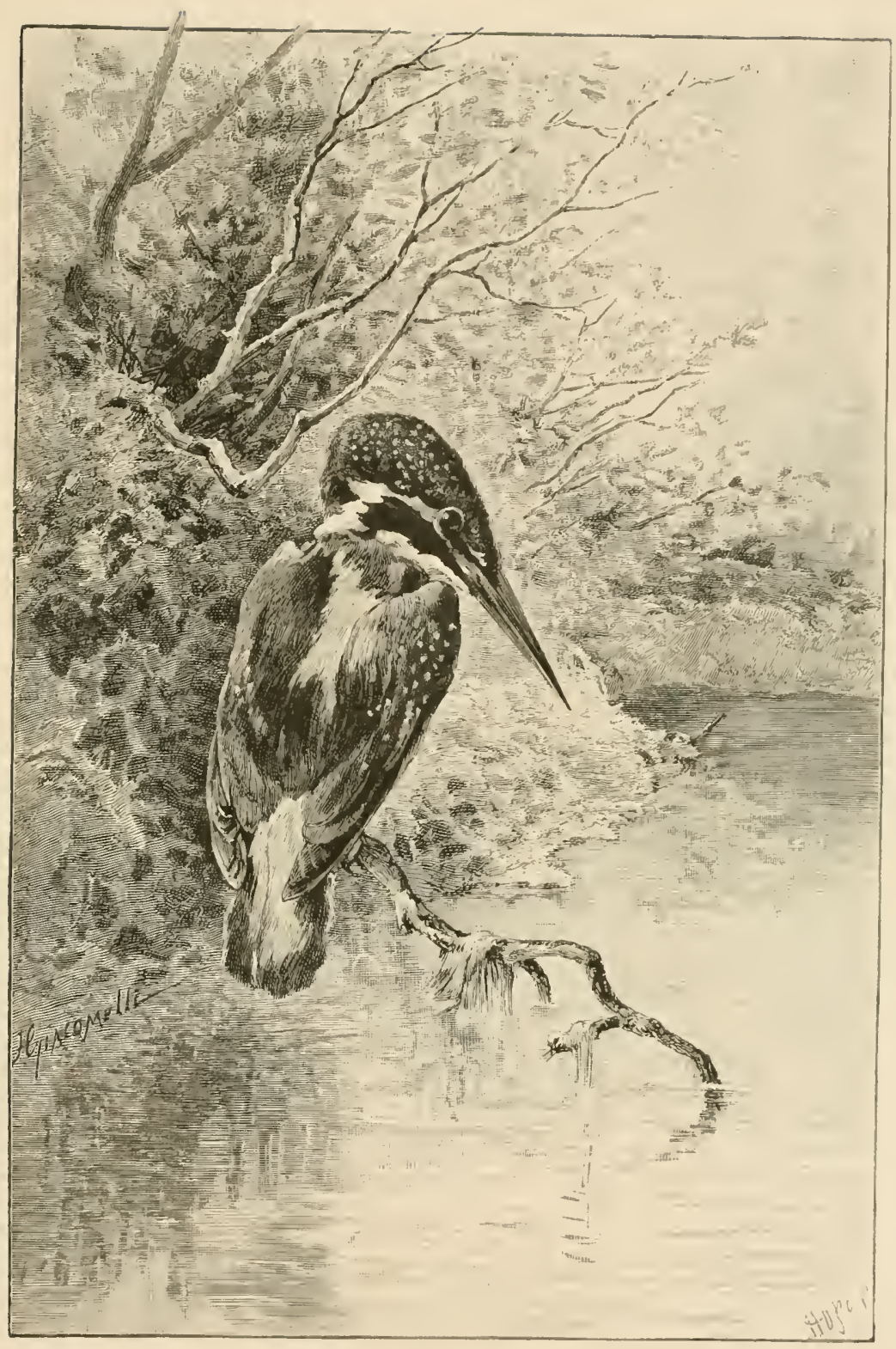

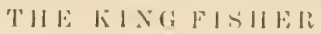



see it ordinarily posted on dead branches, they say that it dries up the wood on which it perches. In Buffon's time, people had noticed that worms rarely prey upon its dead body, and therefore good houservives attributed to it the virtue of keeping away moths, and used to suspend the dead bird in the midst of their woolen garments.

But everything is getting vulgar and mean, even superstitions. In losing its melodious name of Alcyon, the unlucky king-fisher has lost even that poetical halo which still shines after death.

Whilst I was giving myself up to these reflexions, the hot July afternoon was drawing to a close. The sun was already lower and shooting oblique beams under the arch formed by the beeches, and the rays were running over the black surface of the river, like some marvellous golden-hued insect. At the same time a breath of fresh air was shaking the leafy bowers, making here and there an opening for the light to pass, ruffling the surface of the rivulet with golden ripples. Then, little by little, the illusion would die away, and I could only see water spiders dancing a fantastic ballet on the placid waters.

'The king-fisher' would again shoot across the darkness like the fitful glimmer of a rainbow. He would turn ever and anon about the level of the current, like an experienced marauder who knows that the hours of twilight are more favourable for his sport. Then suddenly he wonld dis appear under the water, reappear all dripping, carrying away 
some fish in his bill. whilst flying towards his nest. I would hear a concert of shrill pipings in the distance, issuing from the knotted roots on the banks of the river. It was thus that the birdlings were welcoming the return of the ling-fisher and his booty.

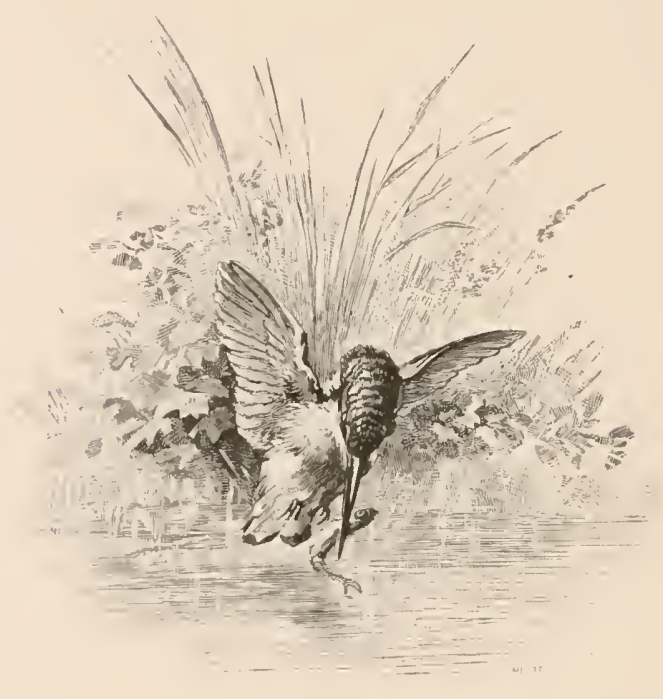




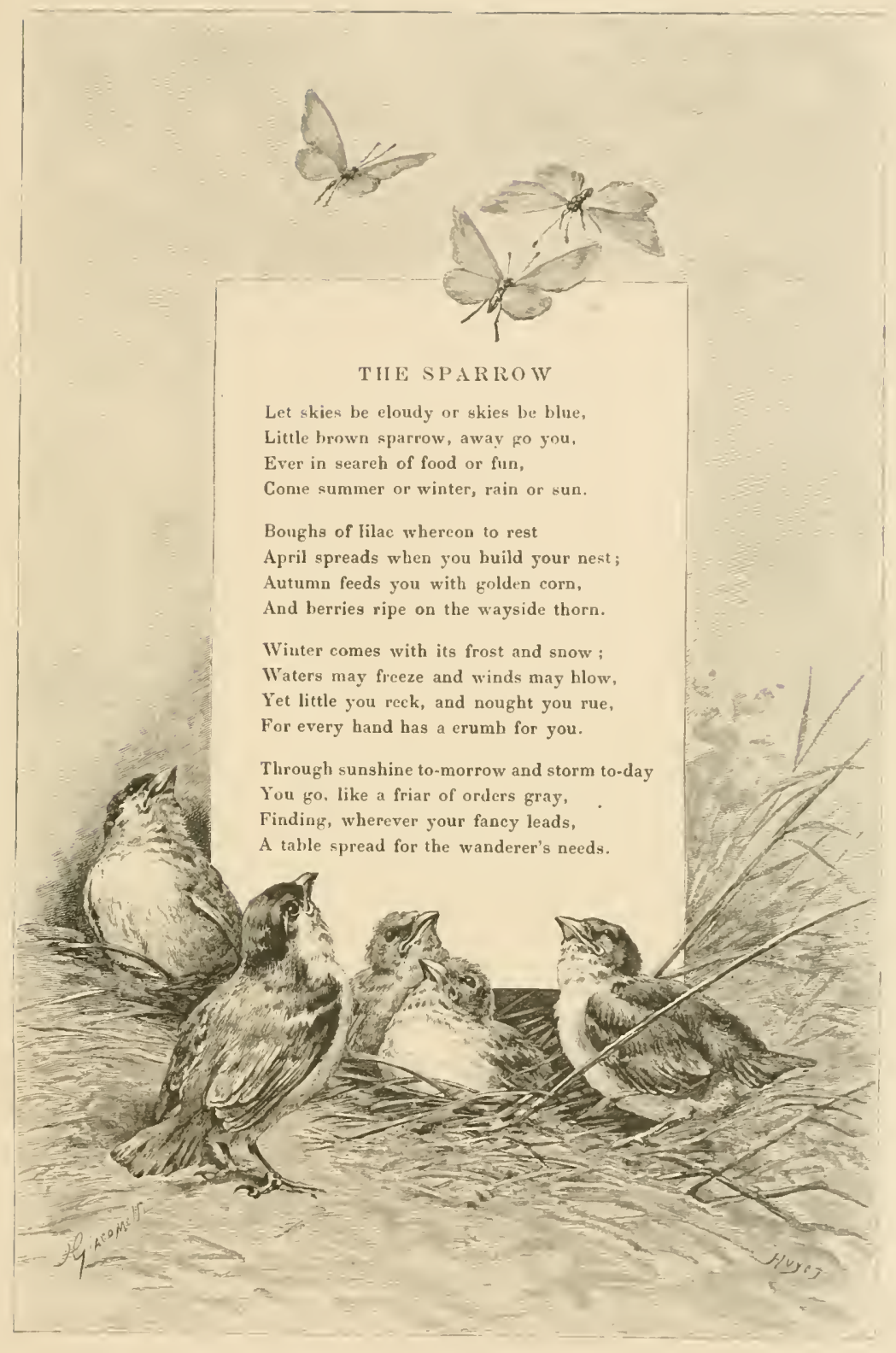





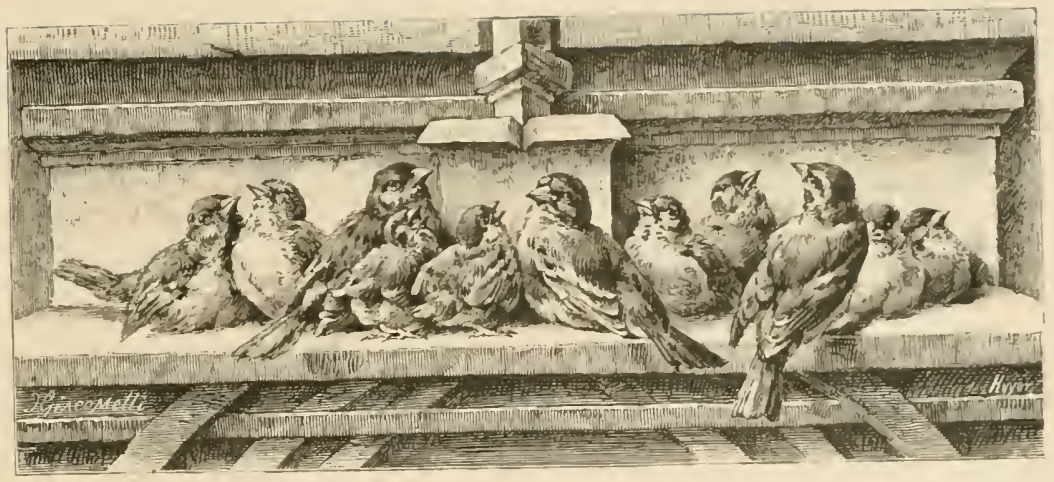

\section{THE SPARROW}

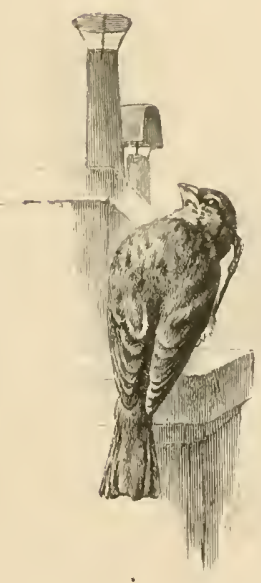

The sparrow is like the lark a bird more particularly found in France. Whilst the lark represents certain lyrical sides of the French race, its dauntless buoyaney, its spirited liveliness, the sparrow, is the emblem of gallic petulancy, of the noisy, jolly animal spirits of the people of Paris. Therefore it is in Paris where one can best observe the habits of these sharp, impudent, pilfering birds of passage. 'They congregate in swarms on the roofs of Parisian houses, in the noisiest streets, in the most frequented gardens. Clad in a grey and brown 
costume, scarcely brightened up by a white and black tie round the throat and a yellowish line on the wings, the sparrow, with its vulgar manner's, its monotonous, cry, makes no outside show; but it is one of these people that one must not judge by its clothes. It is like one of those ugly persons, who are bewitching when their features are in full play. The charm of the sparrow consists in the saucy lireliness of its hazel-nut coloured eye, in its skipping movements, in the play of its frolicsome countenance and the pretty wagging of its head.

In Paris sparrows are in their true medium. The Parisians are fond of them and they are fond of the Parisians, and the jolly, saucy bird is impregnated with all the faults and all the virtues of the population in the midst of which it lives familiarly. It loves the noisy, animated public roads; it is fond of crowds, and it has taken from the Gamin de Paris, the taste of loitering about the streets like a vagrant. It is not very domestic. Its brother, the tree sparrow, builds a regular nest on a tree; the Parisian sparrow, nestles rather at random, in the hole of some wall, in the gutter of a roof, or behind some window shutter. There, lastily, without any artistic rules it piles together all sorts of rags, bits of straw or hay, but only just what is necessary to build and line a nest. It does not loiter long in its dwelling. The noises of the street are too tempting to be resisted. Presto! As soon as the young ones are feathered, you can see them flying on the 
paving stones. It is not rare; in the Tuileries or Luxembourg gardens at the turning of some shady walk to meet a sparrow, the head of the family, the young ones trudging after the father, hopping and piping, and opening wide their large yellow bill for the father to feed.

Although the nest of the Parisian sparrow is far from comfortable, still it is rarely empty. As soon as one brood has moved out, another one talies its place. The female sparrow is remarkably prolific, and her progeniture can rival even that of Mother Goose's "Old Woman who lived in a Shoe. ") From the beginning of May to the end of September each couple has hatched at least three broods. The rapid multiplication of these roguish birds is the despair of gardeners and cultivators. In Paris, where vinearbours and fruit walls are rare, the pilfering disposition of the sparrows does not draw on them public reprobation; on the contrary, the population is rather prone to encourage and to develop it yet more. Hardly a Parisian exists who does not feed regularly a sparrow or two. The civil service officer, the clerk going to his office, the shopgirl on her way to her place of employment, stop on their way in the Tuileries to throw a handful of crumbs to some band of sparrows. Between eleven and twelve in the morning you can see on all window-sills many charitable hands preparing a meal for these happy and amiable vagrants.

Ye frisky, talkative sparrows! You are indeed the 
-poiled guests of the great city, the cheerfulness and animation of the Parisian streets:

\author{
Fearless, confident and bold \\ Birds by thousands flying, \\ Flapping esery slining wing \\ Fill the air with elattering, \\ And wilh thedglings reared to rove. \\ Like themselves, orer field and grove. \\ Pilfering where'er they go \\ What they choose for forage, \\ Whatsoever farm or field \\ Garden-plot or park may yield, \\ Whether atumu reigns or spring, \\ The winged nation thrive and sing!
}

- In the whole city their cover is laid and they know it well! They know where the best morsels are awaiting them and are sure to be there in time. It is marvelous to see the rapidity with which they communicate to one another the news of some extraordinary treat. An old gentleman was telling me that every morning after breakfast he was in the habit of distributing bread crumbs to about twenty sparrows. One day, having exhausted his stock of bread, he gave them cake instead. The sparrows, liked this change of fare and probably told their friends and acquaintances about the good luck that had befallen them; for the next day the old gentleman found that he had sixty guests instead of twenty. 


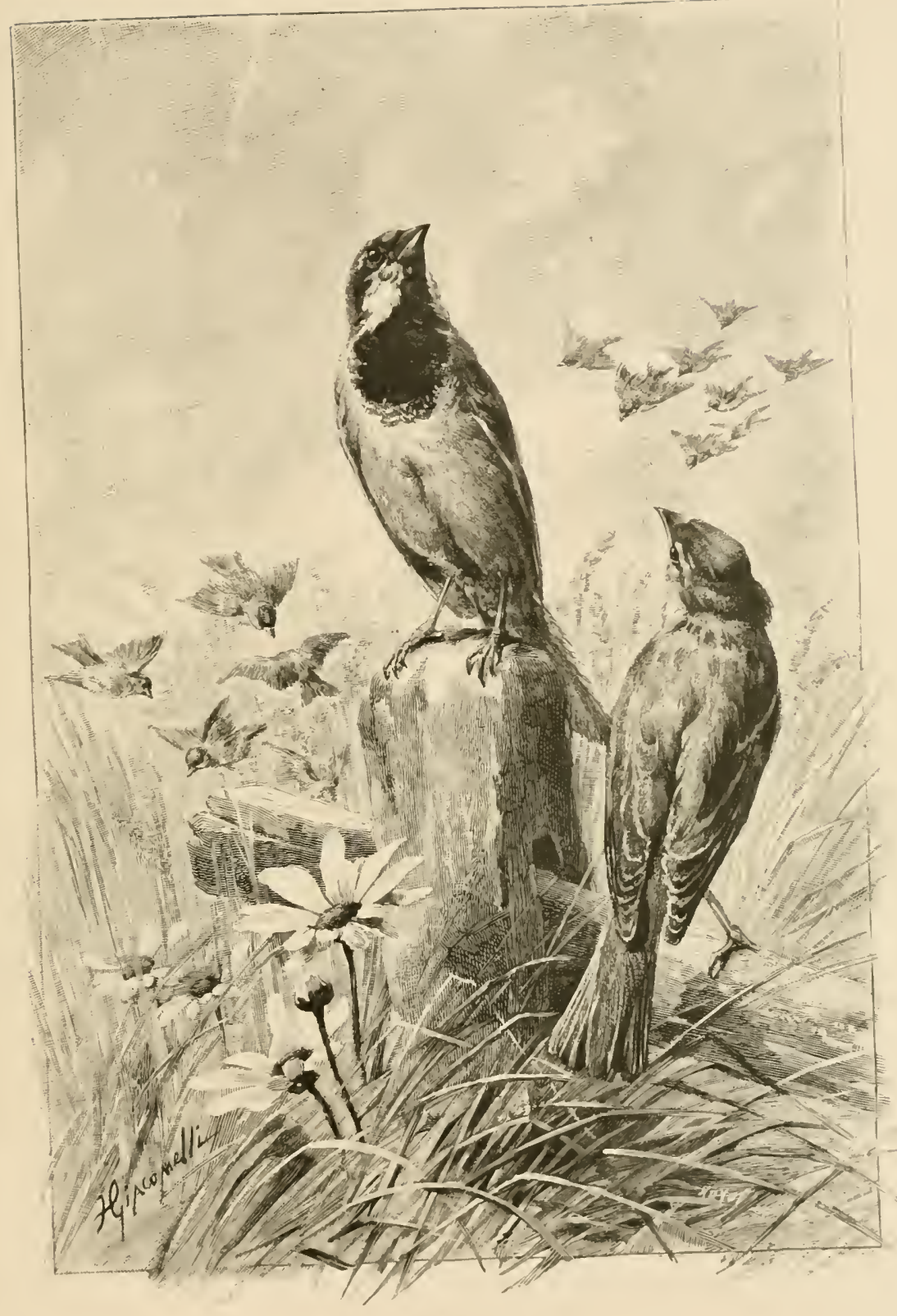

THE SPARROW 

Qu'on aille soutenir, après un tel récit,

Que les bêtés n'ont pas d'esprit

(Let it be said after this, that birds and beasts have no intelligence!)

In the fine scason they put a cage on a balcony near my dwelling, in which some canaries are chirping from night to morning. As soon as their daily portion of millet and chickweed has been placed in their cage, the sparrows who have been watching the proceedings from the opposite roof, hasten up shrieking, and the brazen-faced creatures who know no fear, pick away the best of the millet and chickweed in spite of the indignant cries and protestations of the canaries, which only excite yet firrther the boldness of the marauders.

In summer, the life of the Parisian sparrow is a long holiday, an uninterrupted season of love making, of abundant, and choice dinners. But summer does not last forever. Gradually, autumn is approaching; the leaves of the chestnuts fall with the cool days of September. Sparrows, with their subtle scent, have a presentiment of short and rainy days, of long, cold nights, of snowcovered roofs, of muddy streets, closed windows, of searcer, and less choice dinners. You can see them congregate on the large trees in squares and gardens, taking counsel together. Will winter be there soon? Will it be serere? Is it necessary to think seriously of laaving the country? Their instinct tells them that yonder, beyond the city 
gates, there are ficlds that have been freshly sown with good grain, and farms with well-stored granaries. The greediest, the least courageous birds decide to leave the country, and suddenly you can see flights of sparrows leaving the thin foliage of the trees to emigrate towards the plains of the provinces of Beauce and Brie.

But the true Parisian sparrows, those who love the big eity even in its winter ugliness, do not leave it. Brave little creatures as they are, they set at defiance ali the evil chances of the winter season, quarelling over stray bits of food under the very hoofs of the horses; finally they go and rap with their bill against the familiar windows which just open to throw some crumbs to these faithful friends of good and evil diass.

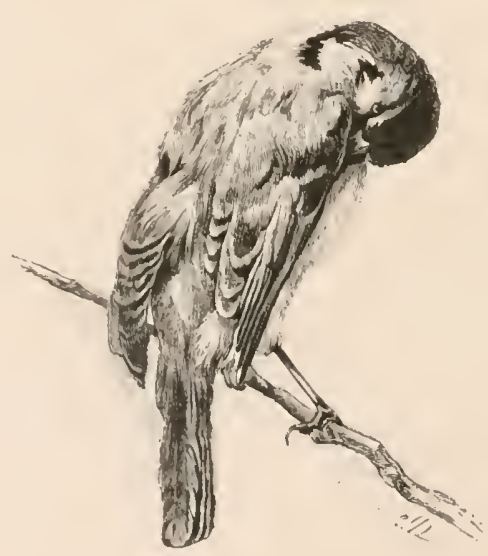




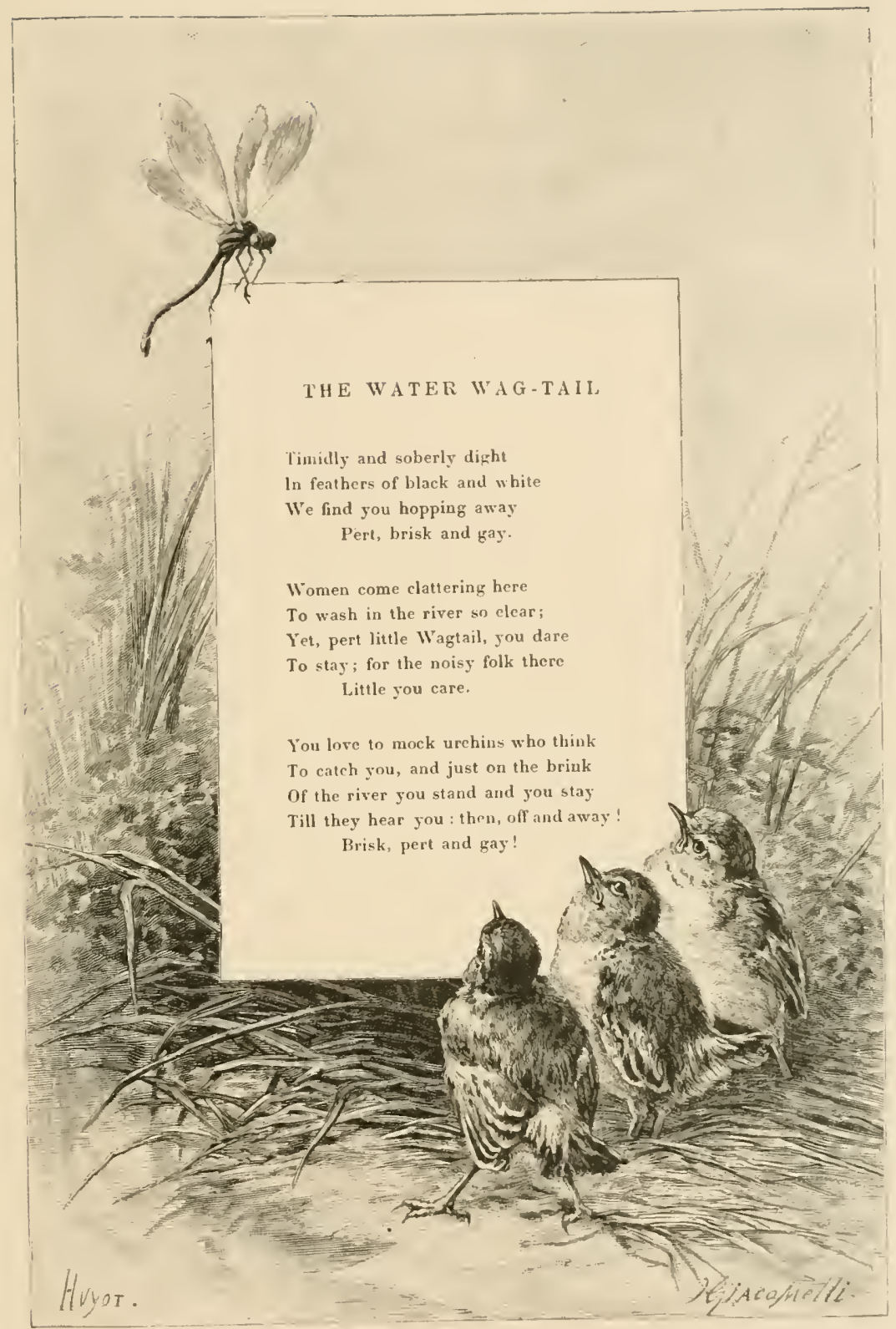





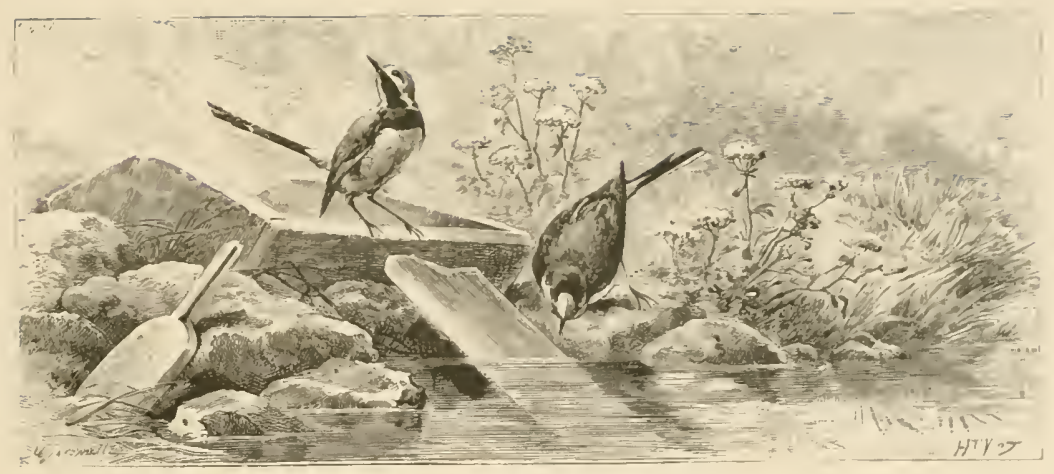

THE WAG-TAIL

Under this generic name people often confound the ordinary wag-tail and the dishwasher. The habits and costume of these two birds are however very different. The plumage of the wag-lail is yellow with an olive brown tint; it dwells in prairies where cattle comes to graze, or it flutters about in the fields following the labourers: the dish-washer on the contrary is clolhed in black and white and prefers to frequent shallow rivulets or the banks of rivers. They have in common certain particular traits of lace and gait: both have a fine bill, thin, long 
feet, a long tail which they are incessantly wagging, whence the French name of "hoche-queue ") (wag-tail) given to them in the province of Lorraine. They are great devourers of flies and gnats; but the dish-washer prefers river-flies, whereas the wag-tail has a weakness for large blue-bottle flies.

The dish-washer is a friend of strands and damp river banks; it likes to haunt mill-dams and the neighbourhood of washing-places. Neither the noise of the mill-wheel, spluttering about its drops of white foam, nor the noise of the washerwomen agitating their beetles, can frighten them. They trip with quick, nimble tread over stones and gravel; they dip their feet into the water and are perpetually wagging their long white and black tails, as if they were trying to imitate the motion of the beetles on the linen.

These birds emigrate in winter and do not return till the end of March. They build their nest on the ground near hollow river banks, or under stakes of wood built up near the river. Their nest consists of dried grasses and small roots, lined on the inside with feathers and hair; the female wag-tail lays four or five white eggs, covered with brown spots. She is a very good mother, very proud of the neatness of her dwelling, which she keeps most scrupulously clean like a very careful houselieeper.

When the birdlings are able to fly, the father and 
mother take them along the banks of rivulets and keep watch over them for about a month longer. Quite recently, on the banks of lake Annecy in Saroy, I witnessed the restless uneasiness and agitation of a couple of wag-tails, one of whose fledglings had got astray under a garret-window and was not able to get out again. Not only the wag-tails chaperon their children, but they teach them to catch flies whilst they are taking their flight. You can see them then rising by starts, turning round and round, wheeling about by means of their tail which they spread out like a fan; whilst they are fluttering, they utter a low, sharp, shrill, redoubled cry, having a clear, distinct sound.

The dish-washer is a very nervous bird, its vivacity is almost restlessness. It appear's to be very familiar, and yet it is very difficult to catch. As soon as you approach. it will fly away ten steps further, perch somewhere else wagging its tail, as if it were setting the person who is pursuing it at defiance; then again it will take its flight, and these proceedings go on for hours. One of my friends, a poet, has tried to characterize in a few verses the nervous, deceiving flight of the dish-washer :

Elle semble. la belle,

Un maitre de chapelle

Blanc et noir,

Qui rythme la cadence

Du moulin et la danse

Du battoir. 
Elle crutit sur le sable

Elle s'envole, semblable

Au désil

Qui toujours uous derance

Et qui fuit des quion pense Le saisir...

(" Like a capel-master, the beautiful bird, in black and white garl, seems to be marking the rythm of the mill and the motion of the beetles of the washerwomen.

It runs on the gravel, it takes its flight onward and upward; like our wishes, it flies off' as soon as we hope to scize it. »)

The grey and yellow wig-tails have more pastoral habits. "The wag-tail, which lives on flies, ” says old Belon, "loves to follow cattle, knowing that it will find food, and it is perhaps for that reason that we have called it (Bergerette ) (Shepherdess). It is more sedentary in its tastes than the dish-washer and does not leave us even in the bad season. In winter, it gets nearer to villages, sceks shelter near the binkis of ponds which freeze only rarely, and there, in spite of cold, it sings a low, solt, discrect strain. As soon as the month of March brings back the season of ficld labour and sowing, you can see the way-tail following the labourer who is pushing his plough, or perching on mounds of fresh soil where it is sure to find an ample provision of worms.

In April it begins to build its nest in the fields or sometimes in the roots of some tree on the banks of a 


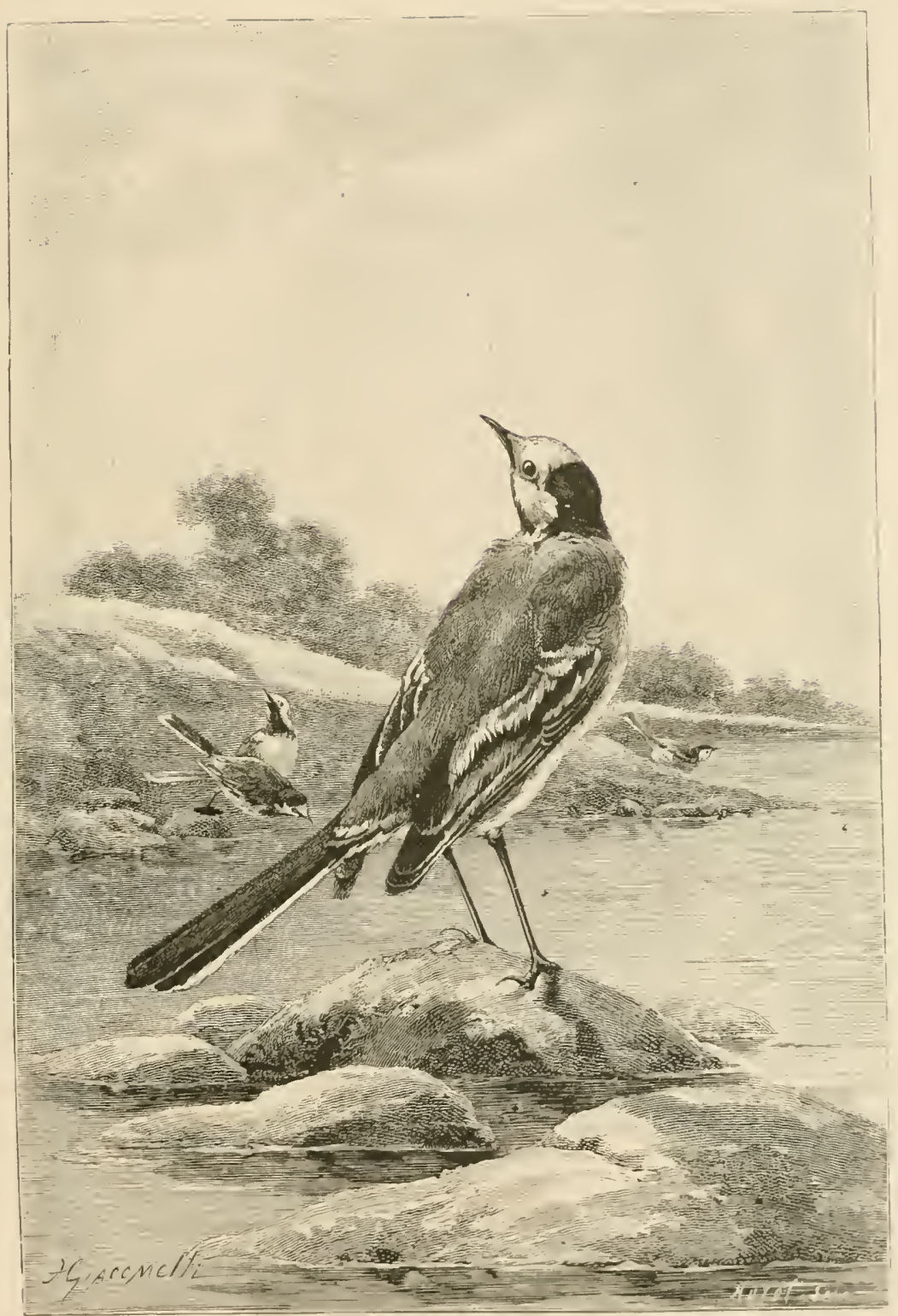

TII E WA TAIL 

rivulet. The nest, placed on the ground, is very much like that of the dish-washer, as far as choice of materials and lexture is concerned, only it is interwoven more carefully. The female lays six or seven eggs; they are of a whitish hue with yellowish spots. When the young ones are fledged, towards mowing-time, the father and mother take them to some new-mown fields where the cattle are taken to pasture.

Then begins an idyllic life for the wag-tail. The big, russet-coloured oxen are lying about on the short grass of the pasture-commons; around them, swarms of flies are buzzing, and to the right and left bands of long-tailed birds dart on the insects, without being in the least frightened by the neighbourhood of the weighty ruminants. Some of the wag-tails are daring enough to perch on the black horns of the cows. Others follow the sheep dispersed about the commons, following the lead of the shepherd, who wallis ahead, wrapped in his cloak.

In the XYIII. century, when naturalists yet lent to the animals they were studying the sentimentalideas that were then the fashion, they pretended that wag-tails were so fond of the shepherd as to warn him when a wolf or a sparrowhawk was drawing near. This story is as ingenious and pretty as it is unlikely. Wag-tails care little about the wolf of whom they have nothing to fear'; as to the hawk, they are very much agitated when they see it soaring above the pasture-commons, it is therefore only interest for their 
own preservation and not friendship for the shepherd who does not fear that bird, which causes their warning, for a hawk will attack birds but never flocks of sheep.

All day long the wag-tail will follow the herds in their evolution. Now, evening draws near : the shadows of the elms lengthen on the plains; light mists arise in the back ground; the moon shows her crescent above the dusky woods; the shepherd is blowing his horn to call his scattered sheep; pushed by the dogs, the flocks rush forward on the dusty road, bleating noisily, the bellowing cows turn their heads lowards their stable, and in the rear, hopping over tufts of grass, wagging their tail and littering low, shrill cries, the wag-tails accompany the herd to the extremity of the fields.

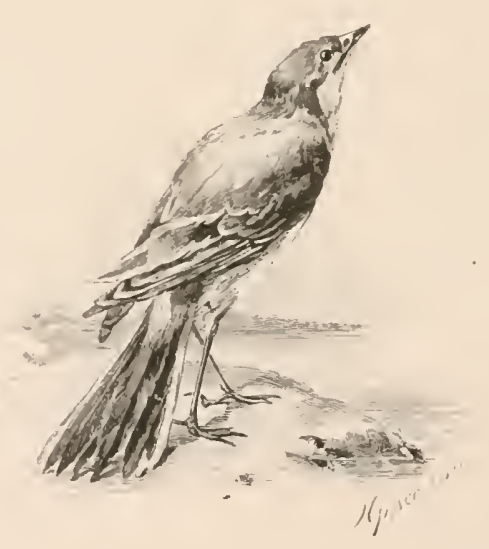




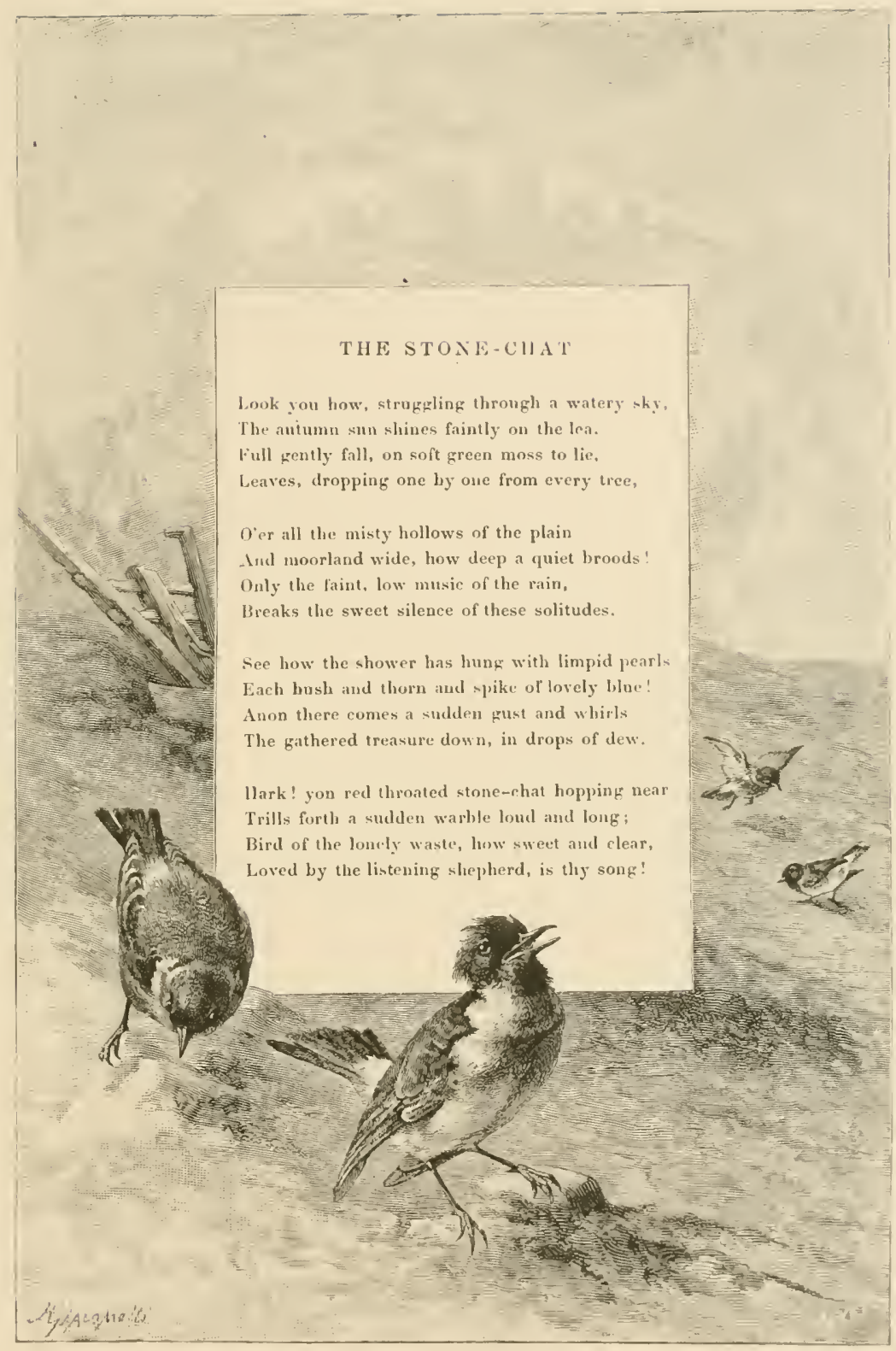





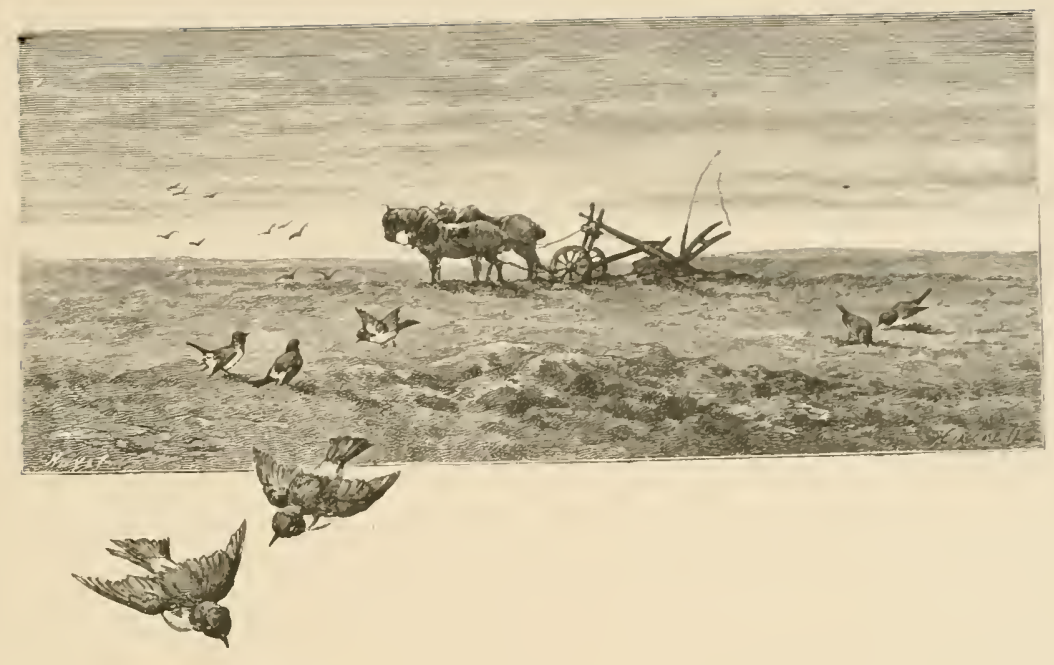

THE STONE-CHAT

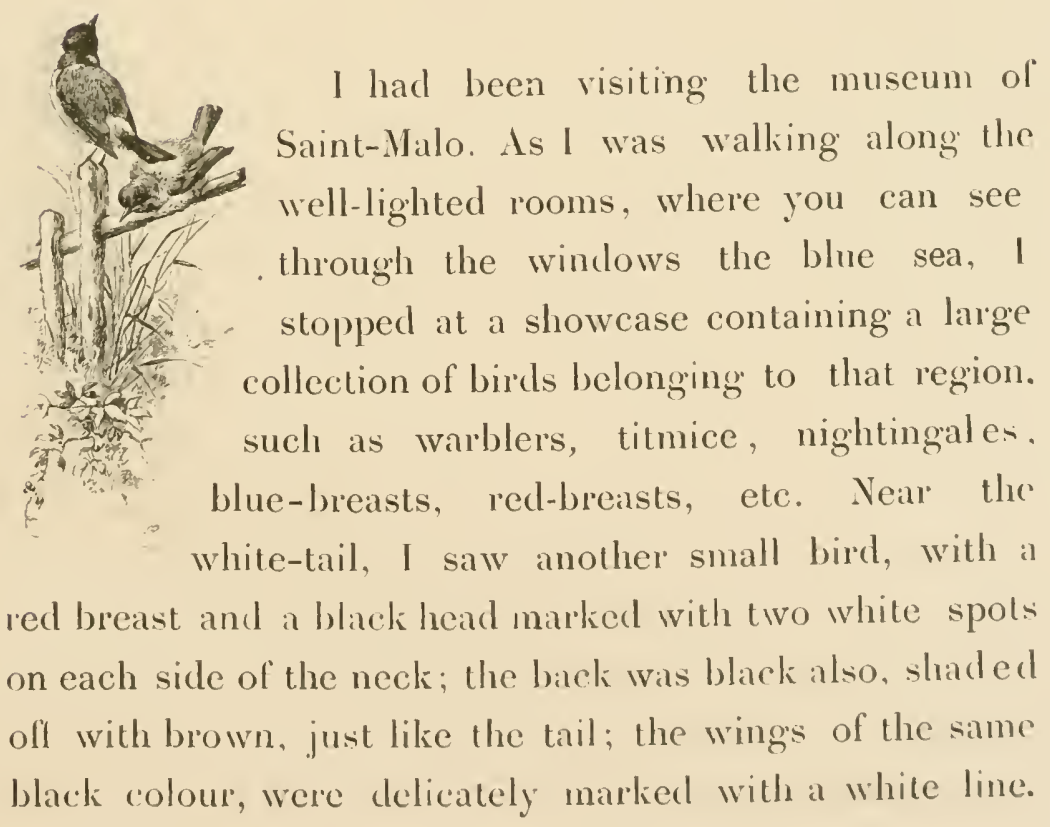


I recognized the stone-chat, which they call the hammerer in my province, and the description that old Belon has given of it recurred to my mind: "You can see it perching on the lighest tree-tops, constantly flapping its wings, on account of this unceasing restlessness they call it traquet or mill-chapper; for as the mill-clapper never stops, as long as the mill-stone is grinding, so this restless bird is for ever flapping its wings. ")

Satisfied with having seen the stone-chat again, I left the musemm, recalling to my mind the pretty countenance of that lover of bushy moors. I crossed the narrow streets of Saint-Malo, lined on each side with tall houses, and I was drawing near the sunshiny quays, where I could sce the outlines of multitudes of masts, clearly defined on the surface of the greenish white sea. The wind had risen, the boats were daneing along the slips, and I could perceive beyond the wall of the quay the tops of their masts rocking to and fro. On the opposite side of the bay, Dinard was spreading out in the sun its terrace-like gardens and its Italian villas. The boats were now leaving the slips and taking aldvantage of the wind to sail towards the river Rance. The steam ferry boat, filled with passengers, was slowly crossing the bay, leaving behind it a long wake of white foam. The animation which secmed to reign on the water and in the air induced me to take a trip also: so I jumped into a boat, and told them to take me to the Point of ficomte. There, I climbed up the 
woody slope and found myself soon in the middle of a large moor.

The pasture-commons were bordered by thick hedges of brambles and woodbine; these commons stretch to a long distance, separated here and there by some rather barren ficlds, where, nererthcless, a meagre crop of golden corn and light yellow oats was growing, marking light spots on the rast extent of the moor. I was turning my back to the bay which was hidden from my riew by a wood of beeches, but I could hear the low, rythmical rising and heaving of the sea. On a holly-covered hill, a shepherd was watching his russet-brown cows buried up to their knees in the greyish verdure of the furze. A profound silence, a great calm was reigning all around ; cren the light secmed to be toned down, the sun being reiled by white clouds. Suddenly, I heard a low cry repeated sereral times : Ouip! tiay! tiay! Ouip! tiay, tiay ! And a few steps off, swinging contentedly on a bit of wondbine, I perceived my hirdling of the musemm, with its russetbrown breast, the stone-chat of the shepherds.

Perched on its unsteady stem, already impatient to take its flight, it flew by short starts towards another branch, where it would remain a few minutes and then leave again for some other bough. It represented perpetual motion. Nlthough it never soared high, its black feet never seemed to touch the branches, and they secm to Felong rither to the air than to the ground. While the 
stone-chat was continually dancing on the flexible stems of the brambles and woodbine, it seemed to be perfectly happy, uttering now and again its low, cry: Ouip! tiay, liay! Ouip)! tiay, liay!

The stone-chat builds its nest in waste land, among the roots of entangled bushes; it hides its nest earefully and enter's it stealthily, like a lover who fears to be seen when he visits his mistress. The female lays five or six egges of a bluish green colour, with slight russet-coloured spots near the broader end. As soon as the young ones are hatched, the stone-chat takes great care not to be seen entering or leaving its nest. It never dares to go near it without having made its way through the neighbouring bushes, so ats to render the seareh of ill-intentioned people entirely fruiless, at least as much as lies in its power. W' len it leavesits nest, it takes the same precautions as on entering it; it glides under the branches till it gets to a certain distance, so that one never knows the exact place of its nesting, and it is necessary to search along the whole liedge to be able to discover any trace of it.

penple who are so exceedingly mistrustful are rarely of a rery sociable disposition. Except in pairing-time, the stone-chat lives in solitary retirement. "It does not fly in company with others; it is always alone. " says Belon ; "nevertheless, in the fields it is easily approached, and only flies to short distances. without appearing to take any notice of the hunter. » 


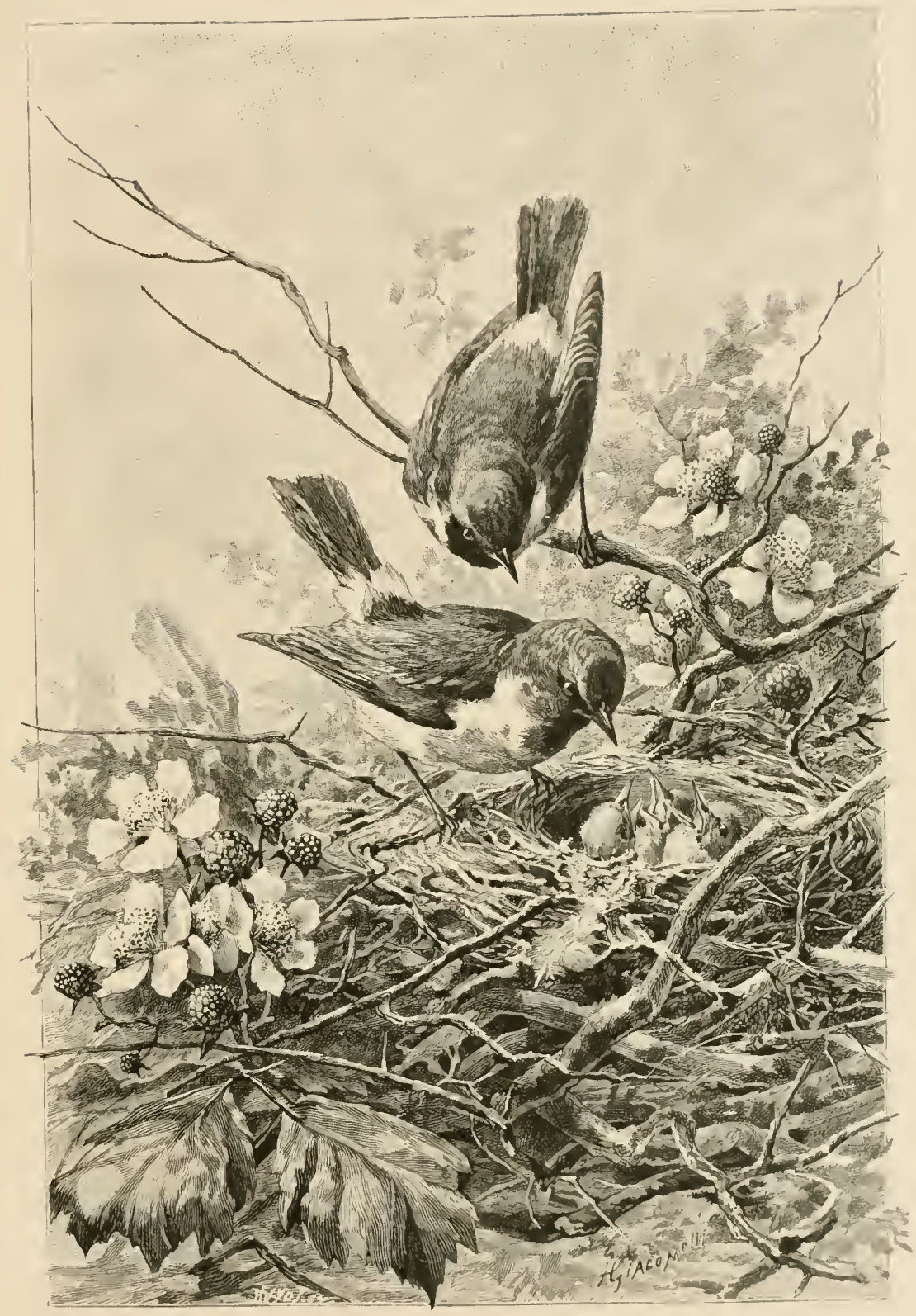

THE STONE-C'HAT 

The stone-chat that I laad been following on the moor of licomti did not seem in the least to pay any attention to my presence. It continued to hop over the furze and the holly, chirping and fluttering all the time. It took me thus a long distance, stopping now and then as if it were waiting for me, and then starting off again as soon as I got up to it. Above, the white and blue marbled sky was shedding a soft light over the moor. Beyond the pasturecommons, above the foliation of the bushes which bent back and seemed to have been clipped by the seawind as by a herkge-bill, I conld perceive the bluish waters of the Rance: and on the opposite shore, the slatecovered cupola of the church of Saint-Servan, the tower of Soliclor, the white villas of Dinard, embowered in verdure; then, behind a rocky point, the elegant spire of Saint-Malo; lastly, quite in the background, the foamy sea, dotted with brown rocks, on which innumerable sails were flying. I was yet listening to the small, solitary bird humming its short song in this immensity, and I felt a sensation of serene joyousness in the presence of these, silent spaces of sky, earth, and air, animated only by the dull chirping of this small creature, at once so wild and so familiar. I enried its viracity and sprightliness. I watched it as it fluttered above the furze, where the cows were still grazing, half hidden in the verdure. Everything seemed to be living and breathing with the placid unconcern of creatures and inanimate things that are sure of 
1 


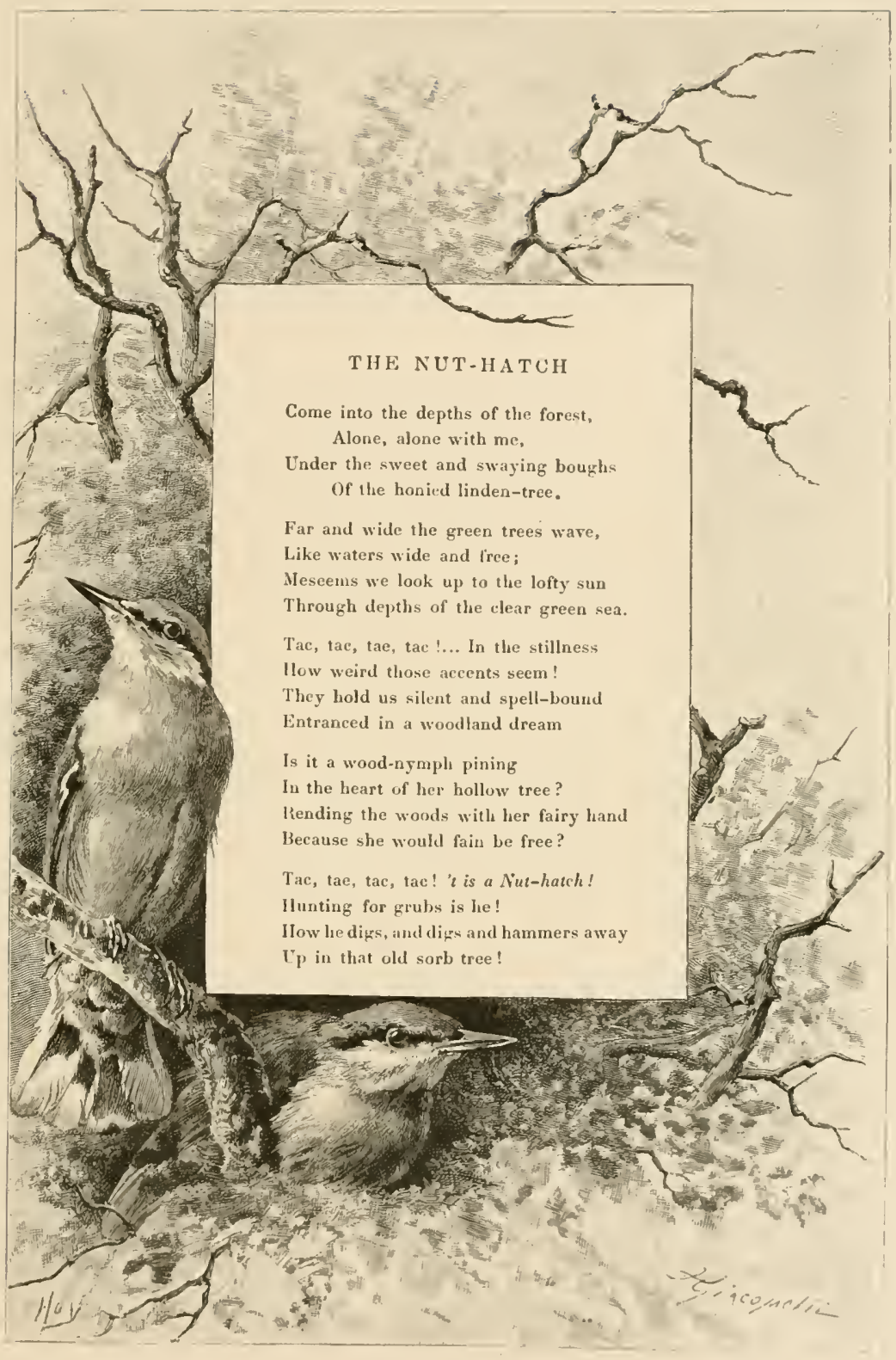





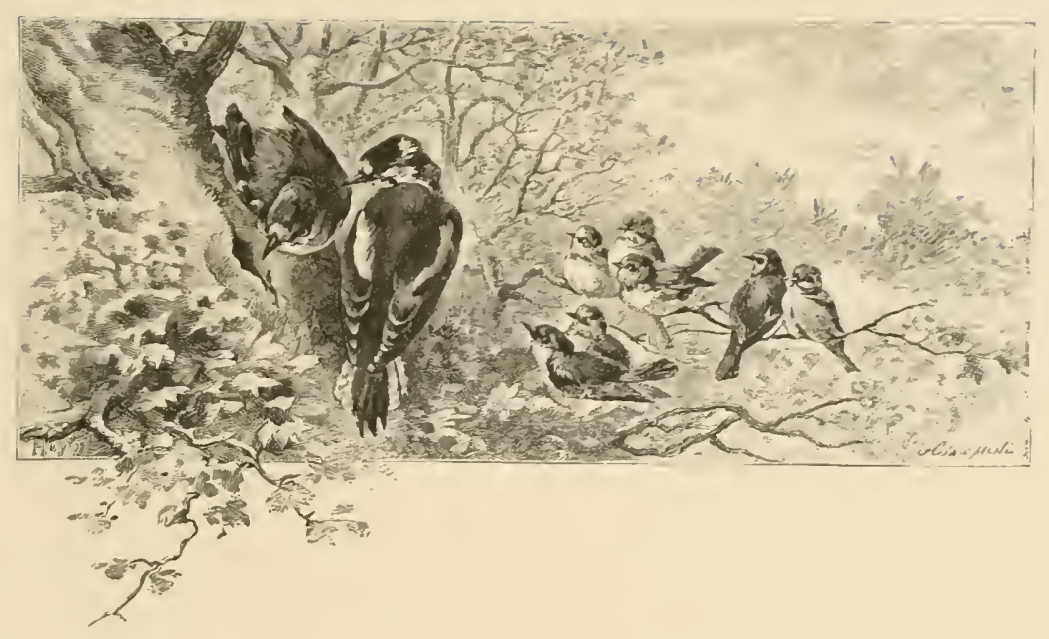

\section{THE NUT-HATCH}

\section{AND THE LESSER WOOD-PECKER}

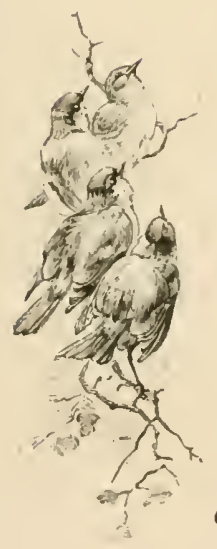

If you have ever rested under the shade of large forest trees, on some fine summer's day, you must have witnessed the amusing gymnastics of the birds of the family of small climbers, such as the lesser red woodpecker, the nut-hatch, the spotted woodpecker, and I should even say the golden crowned wren and the titmouse, if I were not going to speak of these last in a separate chapter. In the distance, in the solemn silence of the big forest, you can hear the shrill cry and picking of the large climbers: the green wood-pecker, the great black 
nut-hateh and the lesser wood-pecker. The small people of this family malic less noise, but accomplish perhaps more. They only utter now and then low aries of appeal, r'mning along the branches and destroying numberless caterpillars, lanrae and egg's of various insects.

The lesser red wood-pecker has the brightest colours. Its spotted black and white plumage is set off by a pure red spot on the top of its head. It is hardly of the size of a sparrow. Like the large witwall, it has all the distinctive traits of the boldest climbers : a hard bill, a long and moveable back nail; its tail feathers are rugged and strong enough to be used as a prop, when the hird, hanging with its back downward, redoubles the clatter of its bill against the boughs. It does not (limb very high, but circulates around the trunk of trees with marvelous agility. In the fine season it builds its nest in rotten trees where dampness has made holes in the boughs; it often has to fight for these lodgings with the great black-headed titmouse; this latter bird, however, not being so strong as the woodpecker with its sharp bill and nails, is obliged to leare the field of battle. Like the great wood-pecker, the female lesser red wood-pecker lays three white eggs in this rudimentary nest, which she patiently hatches on a bed of wood-dust. Thesebirds do not emigrate. In winter they keep near habitations and like to frequent orehards, where they carefully pick all the fruit-trees they can find. This ferreting and picking propensity develops prudence and ingenious- 
ness in the wood-pecker. Its disposition is cunning and distrustful. It is difficult to perceive this bird in the woods; as soon as it has the presentiment that a stranger is approaching, it remains motionless behind the trunk of a tree, and you can searcely perceive a bit of its head, in which an arch eye is glistening. When it is going to take a drink, it flies up to the pond very slowly, by starts, and silently. Then it descends from tree to tree, until it reaches the water, turning its head every minute, like a thicf who has been pilfering and is afraid of being eaught.

The nut-hatch has often been confounded with the group of wood-peckers, but it differs from them in many respects. In Lorraine they call the nut-hatch «Pie maçon », and in some other provinces "Pic bleu" (blue woodpecker). It has their strong bill, but its tail is not so stiff; its own tail is moveable like that of the white wag-tail; this latter circumstance makes the gait of the mut-hatch much more elegant and supple than that of the wood-peckers. $\mathrm{It}$ is of the same size as the lesser red wood-peclier and its feet are like those of the last-named birds provided with hooked nails. The head, back and tail of the male nut-hateh are of a fine ash-blue colour ; its throat and cheeks are whitish; its breast and stomach orange coloured : its wings brown with dark grey edges. Its bill is awl-shaped, rounded off at the end, straight and resisting like forged steel; for this reason the nut-hatch can hammer and pick the bark of trees, making a great noise, 
and when it holds a nut, it pierces the fruit easily; thence its English name of nut-hatch.

It runs over the boughs of trees in every direction. hanging often with its head downward, in search of caterpillars and small grub. It choses its dwelling ordinarily in the depths of the forest where it leads a most industrious. solitary life. It is a silent bird. The only cry it utters when pursuing insects is a soft murmur: li! ti! ti! Sometimes it introduces its bill into the bark of a tree, making a peculiar, loud, jarring noise, as if it wished to frighten the prey it is pursuing, and to take advantage of its disarray to surprise it more easily. In spring. the male nut-hatch has a peculiar 'ry like a roll-call : guiric! gruiric! it repeats this cry constantly when calling its sweet-heart.

As soon as pairing has laken place, the husband and wife both busily arrange the nest, which they have built in the holes of a tree. If the opening is too large, they build it up with mud, leaving only sufferient ronm for their own chress and ingress; they consoliclate this masonry yet more hy mixing some pebbles wilh mud, and that is why this bird in France is often called "Pic macon ). In this obscume nest the lemale lays five or six greyish eggrs. with meset coloured spots. It hatches them assiduously, whilst the male goes to look for food. The young ones are hatched in May, and as soon as they are strong enough to seek their own subsistence, the family separates. "Peasants have observed, "says the naturalist Belon, "that the male 


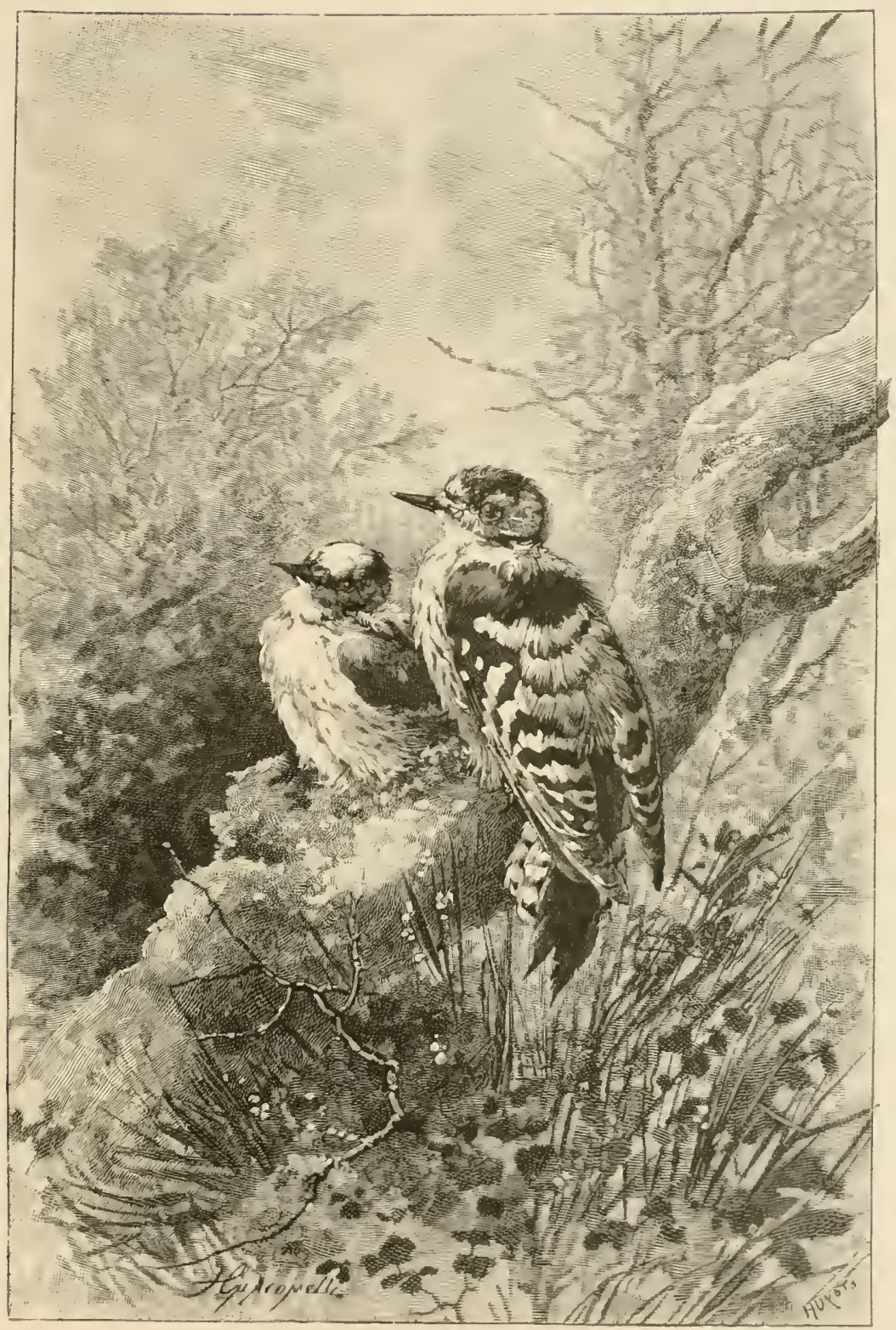

TII E N UT-II ATOH 

bird beats the female when he finds her after she has left him. There is a proverb about people who live happily together in matrimony, that they resemble the nut-hatch n). From this we can conclude than in the opinion of the old naturalist the happiest matches would be those where the wife likes to be beaten.

Be this as it may, family life among the nut-hatches does not seem to be of long duration after the young ones are hatched. When autumn clraws nigh, each male takes its own way. Sometimes they meet later in the season under hazel-nut trees; they do not recognize each other but pick and quarrel over some fresh kernel.

The lesser spotted wood-pecker is yet smaller than the nut-hatch; it is nearly of the same size as the wren and has the extreme agility of that little bird. Its plumage is grey and russet coloured; its throat is pure white and its head has a brownish tinge. It dwells the whole year where it was born, in holes of trees; there it establishes its brood and spends its days picking at moss in the cleft bark of trees. It runs over the boughs so rapidly that it is often confounded with the troglodyte. It is marvelously skilful in gymnastics, and a most ingenious destroyer of caterpillars; it ought to be venerated by all those who are fond of sylviculture. It inspects the trees, branch after branch, living on the leaf-covered stems, exploring them head downwards, or in every other imaginable position. On and under the leares, in every chink or cleft of the 
boughs, it finds thus the grub and flies which constitute its food.

All these lesser climbers have quick movements and a low discreet voice; they are the life of thickets and large forests, where singing birds seldom penctrate. They animate the depths of the great woods. Their light, easy movements harmonize with the ereaking of bough and branches, the rustling of leaves, the murmur of springs in the moss, the dull humming of insects, and all those thousand minute voices of the forest, which apparently silent, are yet never quite dumb.

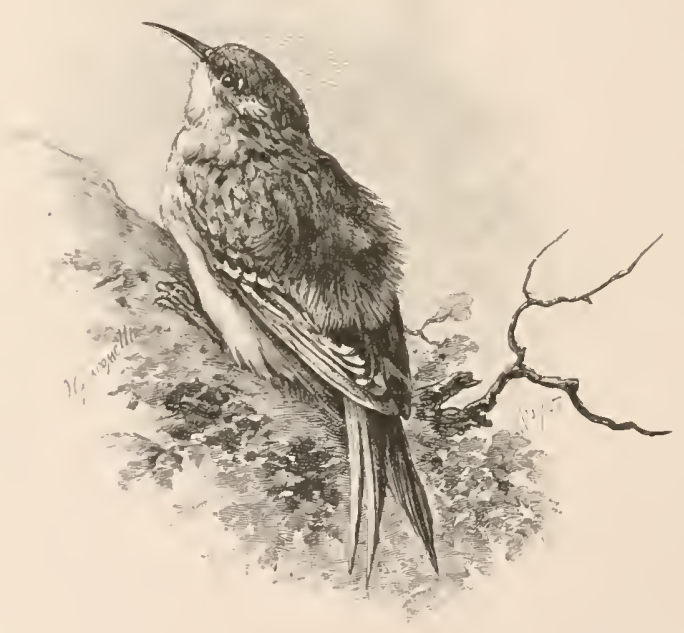




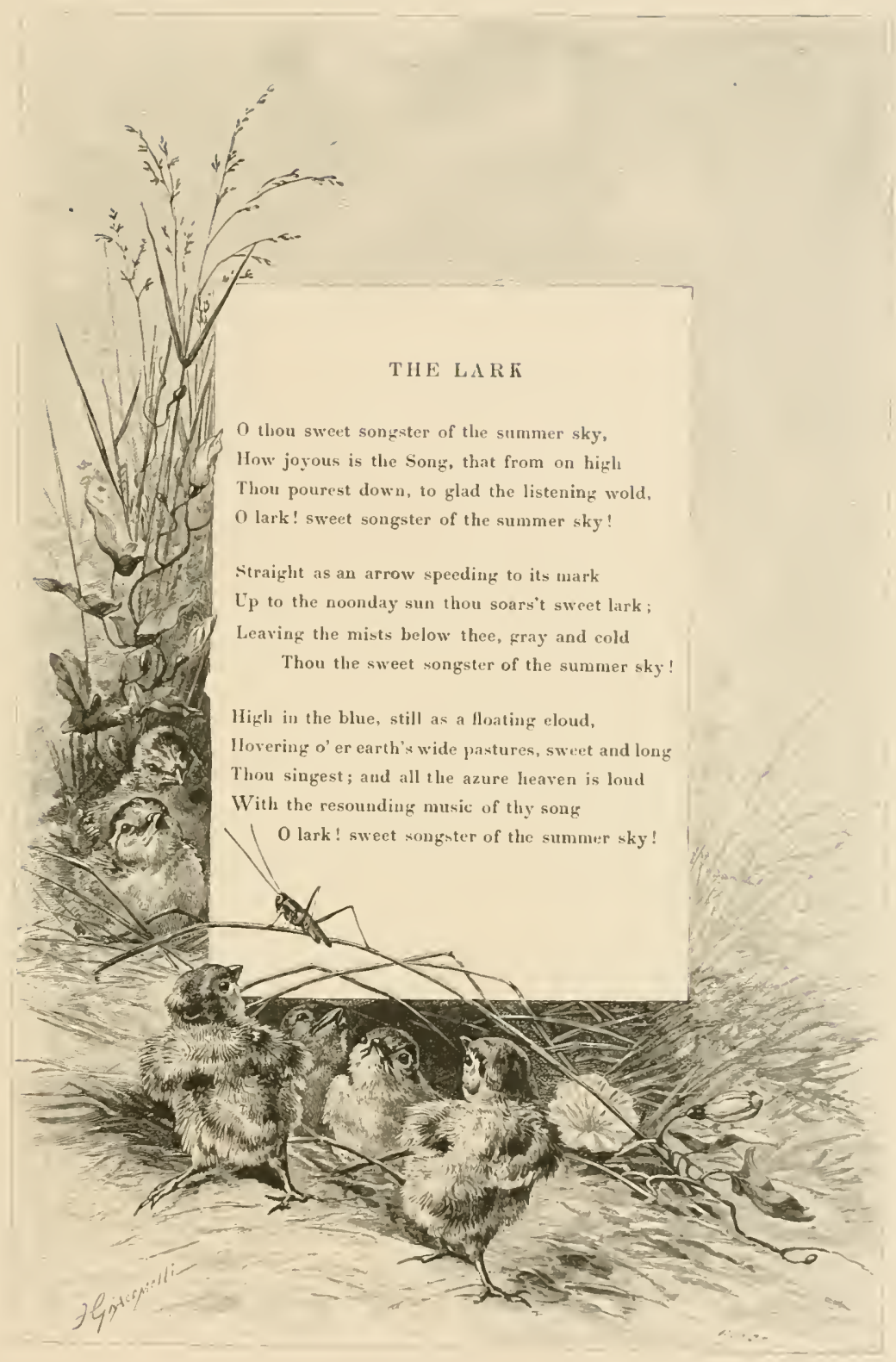





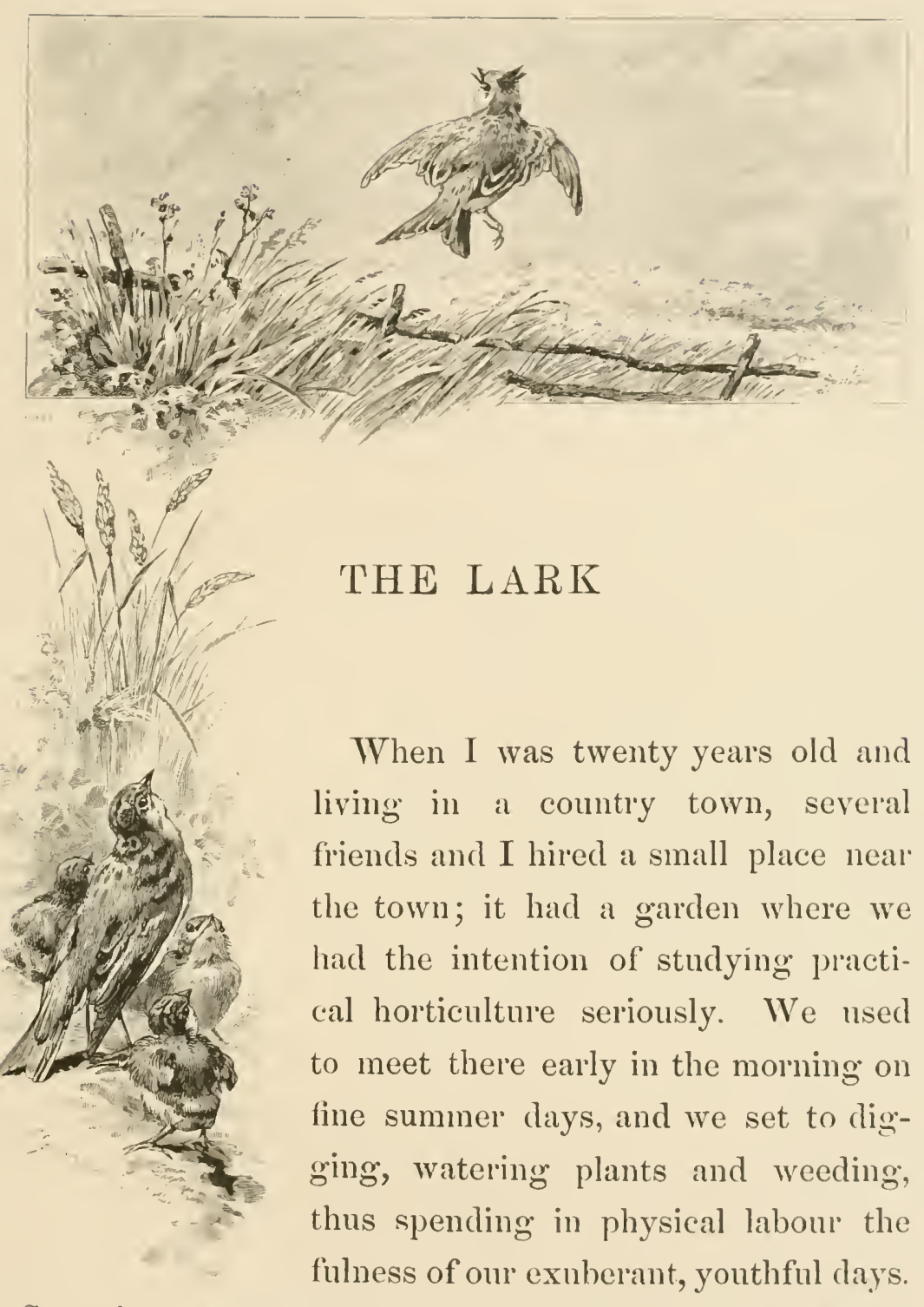

Sometimes we would spend the whole day in the woods and sit down to dine in excellent appetite, after having. 
roasted a leg of mutton as well as we could in the open air.

One evening, I decided on spending the whole night in the same quarters and I settled myself comfortably in a hammock, suspended on the eross-beams of the thatehed roof of our r'ustic dining-1'oom. I fell asleep about eleven o'clock. 'The night was deliciously warm, embalmed ly the scent of pines; across the murmuring branches my sleepy cyes could yet distinguish the golden stars twinkling in the sky above my head; my sleeping-chamber was exceedingly comfortable and I slept soundly all night through, until the first faint glimmer of dawn. The freshness which always falls in woods at sumrise having awaked me, I jumped out of my hammock and began to walk about, so as to restore suppleness to my benumbed members.

The coppice was yet silent. Fine drops of pearly dew were hanging on the leaves and the bladles of grass, so that the gossamer threads between the brambles secmed to be covered with diamonds. When I rearled the extremity of the wood, I was suddenty cheered by a joyous strain which seemed to drop from the pearl-gray sky. On the whole extent of the plain which lay waving before me, hundreds of larks were laking their tlight from among the barley and oat ficlds, rising in short windings and soaring upwards towards the blue, slightly shaded sky. I ronld see their small brown bodies rising whilst they were fluttering in their aerial ascension; then suddenly 
they twinkled in a ray of sunshine and I lost sight of them in the heights of the blue heavens.

I could no longer distinguish them, but their strain, with its merry, crystalline notes was still resounding in the air. You would have thought that the blue space above lad suddenly become melodious and was singing that lovely song. Now and then a lark would drop down from the heights of the clouds, straight as a plumb-line; within one foot from the soil, it would make a winding so as to crouch in some furrow. Another lark would then soar upwards twittering, and all along, from the gray plain to the luminous sky above, there was a constant forward and backward motion of sonorous voices and fluttering wings.

Never had a bird's song given me a fresher and a more delicious sensation than this charming serenade at dawn, and ever since that delightful morning in the woods, I began to love larks.

These birds are untiring musicians. Other birds sing but two months in the year in spring; but larks never tire of charming the aerial spaces. From early April to Oetober they never cease their joyous strain. On the ground they are mute, but as soon as they begin to wing their flight upwards, they become melodious. The higher they soar, the more strength their voice acquires. They seem to be animated and inspired by light. It is not only love that develops their voice, as it is with other singing birds; they continue their song long after the broods are hatehed, till 
the latter end of autumn. Guesneau de Nontheliard thinks that larks sing so long only to sustain each other, and to persuade themselves that they are strong enough to keep birds of prey at al distance. This explanation is very ingenious, hut it does not quite sutisfy me. Of course I anu aware that children and cowilds are in the habit of singing when they are erossing a wond at nightfall, to give themselves courage. In spite of this, I hatre too great a faith in the intelligence of larks to believe them capable of making use of such a childish proceeding. To sing as loud as one can, eren in company, does not appear to me to be a very practical means of diverting the attention of gerfalcons and sparrow-hawks. I prefer helieving that the open air and the sunlight cxhilarate the larks and thus develop their musical powers exceedingly. Generally the male sings londest and best, so as to attract the attention of the female: when he has discovered the one he was secking, he dashes down precipitously and pairs with her.

As soon as courtship and pairing are over, the female builds her nest between two clods of soil and lines it inside with dry grasses. She lays four or five spotted egg's, hrown or gray, which she hatches hastily. As soon as the young ones are feathered, they leave their nest and roan athout the fields under the lead of the mother, and this promptness often misleads those who are hunting for bird's nests.

The readiness with which young larks leare their nest 


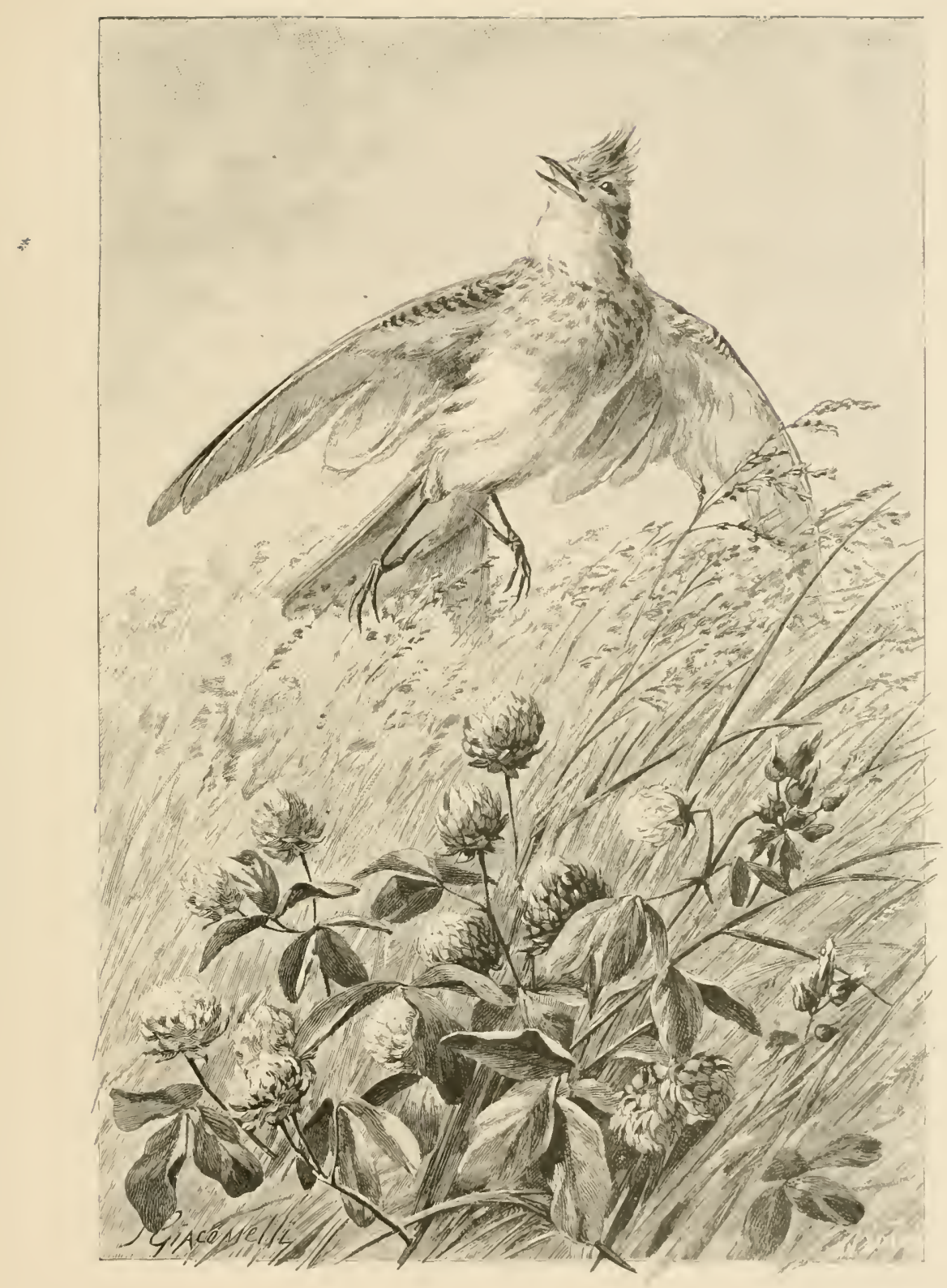

THELAR 

afte: they are hatched, has not escaped the attention of the fabulist La Fontaine. Much has been said to disparage his sense of olservation, but notwithstanding this he was a close olserver of the thing's of nature. In the well-known fable: "The lark and her young ", he has remained faithful to truth when he speaks of the rapidity with which the mother" (lays her eggs, hroods and hatches them hastily", and the firmness with which the mother commands her young ones "to march off in silence ) as soon as the owner of the field has declared his last intentions to his son, is justified by a close observation of the habits of larks and the system of education applied to their young.

Whilst these are tripping over the stuble fields, the mother keeps flying about them with eonstant care and solicitude. She feeds them with worms; caterpillars, ant's egg's and grasshoppers. This however is only the food of their infancy, for as soon as they are grown, they become granivorous and seek their subsistence in vegetable food. In summer, during courtship and parring, the season of song and of bold snaring upwards, larks are very lean; but they make up for lost time towards autumn, when they live more on the ground; eating at all hours, they then grow plump and fat.

Then comes the critical moment of their existence; man begins to hunt and to decimate them. He humts them in every imaginable way, with nets, with a mirror: he uses crery means to destroy these charming hirds ; although 
they render such marked service to agriculture by derouring all kinds of injurious insects. It is true that humter's pretend that they also devour grain. but this accusation is but a stupid pretext for roasting pitilessly thousands of these small birds on a spit. If there is no stop put to this, the whole species will soon be destroyed, and then the joyous strain of the skylark will no longer resound in the air. The pitiless peasant, will be astonished at the silence of the plain; he will regret the merry little bird whose joyous song charmed his rude labour of ploughing and sowing.

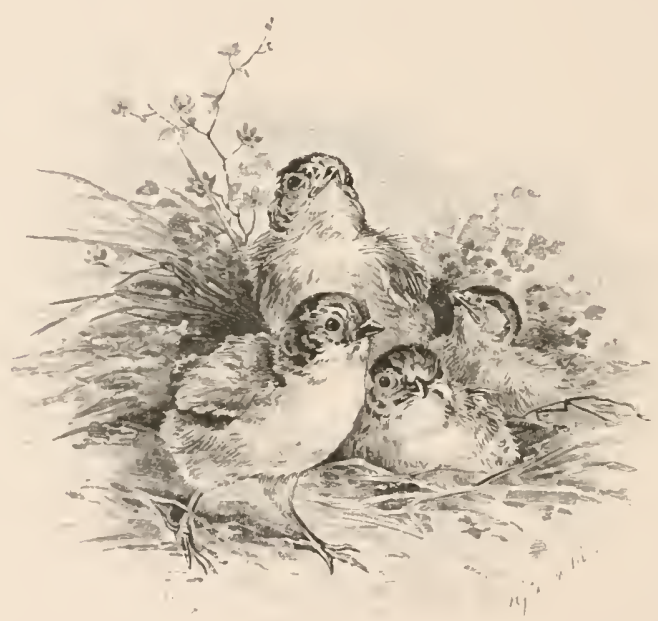




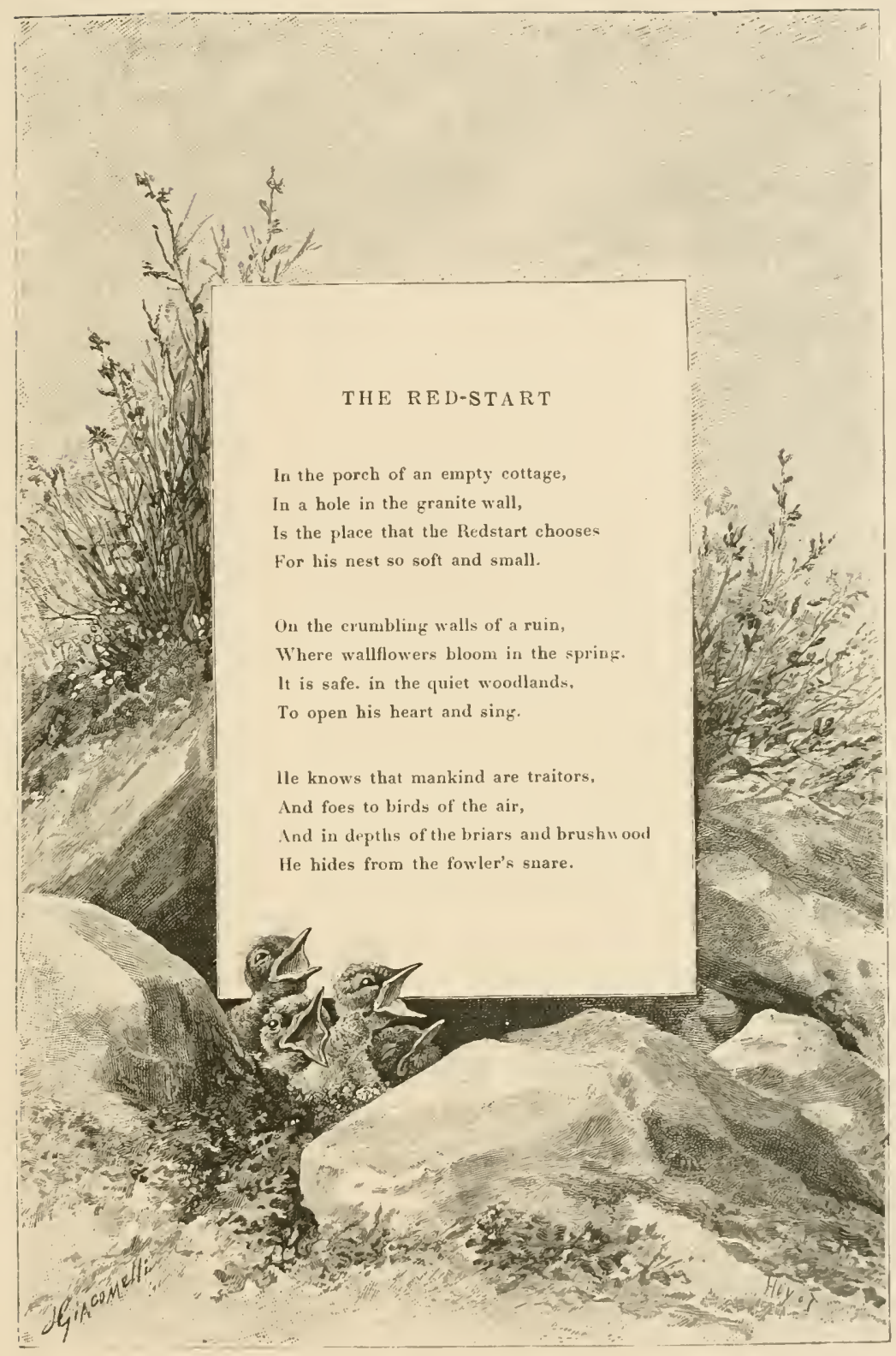





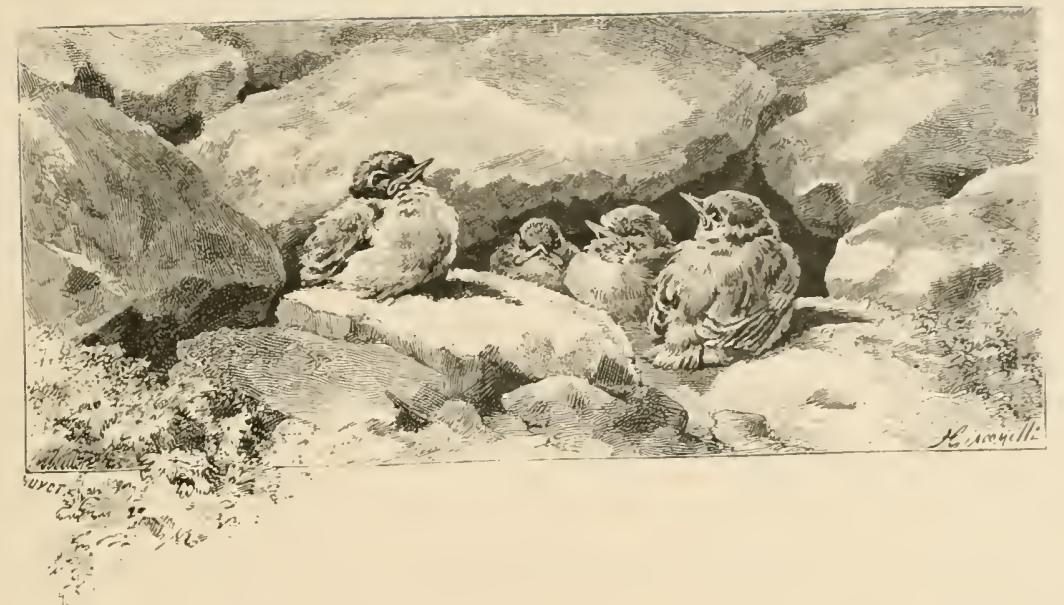

THE RED-START

AND THE BLUE-BRE.ST

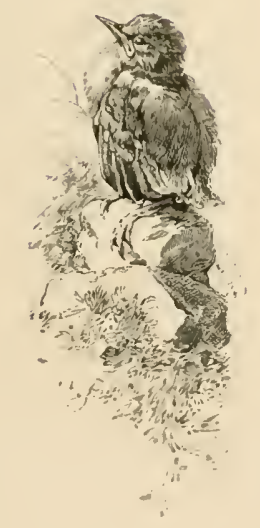

Nthough these two birds difler in colour. they have nevertheless more than one point in common: they are hoth fine singers, with delicate bills and voluble throats and a soft, lovely eye; both are fond of solitude. Ilying from noise and loving intimacy; they come to us in spring and emigrate in antumn.

The recl-start, which is called red-wing in some combries, is smaller in size than its cousin the night ingale; its throat and neck are brown, as well as the line round its eyes; a hrown frontlet covers its forehcad: the 
top of the head and its back are dark grey, the breast of a fine russet red, and this bright hue is repeated on the whole extent of its tail feathers, excepting the two middle ones which are brown. But all these tints are much less marked and much toned down in the female red-start.

These birds are especially to be found in mountainous regions; they prefer to settle down in abandoned huts or on the roofs of empty dwellings: Ruins attract them; they harmonize with the wild, untamed disposition of the redstart. There they find iry-covered walls, tufts of wallflowers, entangled brambles and briers, under all of which they can build their nest in peace. Very often, in the neighbourhood of lake Annecy, in Saroy, whilst I was climbing the steep, rocky ascent which leads to the Touructes, I frightencel some couples of red-starts, who thought they were quite hidden in safety in these solitary pine forests. where no other noise is to be heard but the foaming of mountain torrents, and in the far distance, the feeble, silvery tinkling of the clairin or ('ow-bells, which recall the herds of cattle scattered in the pasture.

The female red-start lays five or six bluish eggs. These birds are naturally of a very mistrustful disposition. It is said that they albandon their nest as soon as they perceive that they are watehed in the process of nest-building. "If any one touches one of their eggs, " says the naturalist Albin, " the red-start leaves its lrnod: if any one touches their young, it will let them starve or it will break their 
neck; this has been shown by experience more than once. ") This explains the care with which the red-start is always on the look-out for crumbling ruins and deserted buildings, for there, at least, it hopes that no intruder will come to disturl it.

If delicate people are unfortunate, those that take umbrage easily are yet more to be pitied. The red-start has nothing of the familiarity of the red-breast nor of the joyous disposition of the warbler. Its disposition is, in the main, a sad one, and something of its melancholy mood has passed into its song, which always seems to be impregnated with sadness, even in the season of love and pairing. All the time the female is brooding, the male red-start remains near the nest, perched on some piece of rock or some tottering stone, and there, from the earliest hours in the morning, it will sing in a sweet voice with varied modulations, which have a faint resemblance to the melody of the nightingale.

It feeds on flies, spiders, chrysalides and small wild berries. Towards the month of October it emigrates, flying across our woods; then it is possible to catch quite a large number of red-starts in those snares of the province of Lorraine, of which I have spoken in my chapter on the Finch. It has been vainly tried to tame them. When a full-grown red-start is shut up in a cage, it lets itself starve, or it shuts itself up in olstimate silence. It is only when red-starts are imprisoned in tender youth that 
it is possible to time them. This is what the parents foresee without doubl. and in their hatred of servitude, with a rombere worthy of the ancicut Romans, they pitilessly destroy those of their children that a profane hand has tourhed, prefering to see them dead rather than dishomomed by bondage.

Althomgl the propensities of the blue-hreast lean also towards solitude. yet its disposilion is not quile so shy. It has the same habits and the sime instincts as its brother the red-herest. It only differs from the latter by the delieate hlue lint which revers its thoat, at the place where the former wears a breast-plate of orange-tinted red. Inder this blue neck, edged with hlack, fawn-coloured plumage is seen on both birds; the ashy tints of the back, the reddish slade of the tail-feathers are the same both on the red-breast and the blue-breast.

'Their manner of chosing their dwelling alone distinguishes the habits of these two warblers. Whereas the red-loreast dwells in the depths of woods, the blue-breast remains on the outskirts, preferring damp meadows, matshy river bauks, where osicr grows in great abundance as well as those decorative reeds that are called rat's tails. There, they spend the fine season, living in couples, huilding their nests in the willows or between the tufts of osicr. 'They have the same love for wates as the reabreast, and they bathe fiequently. You can meet them on slimy banks, scarching for worms and insects, rumning 


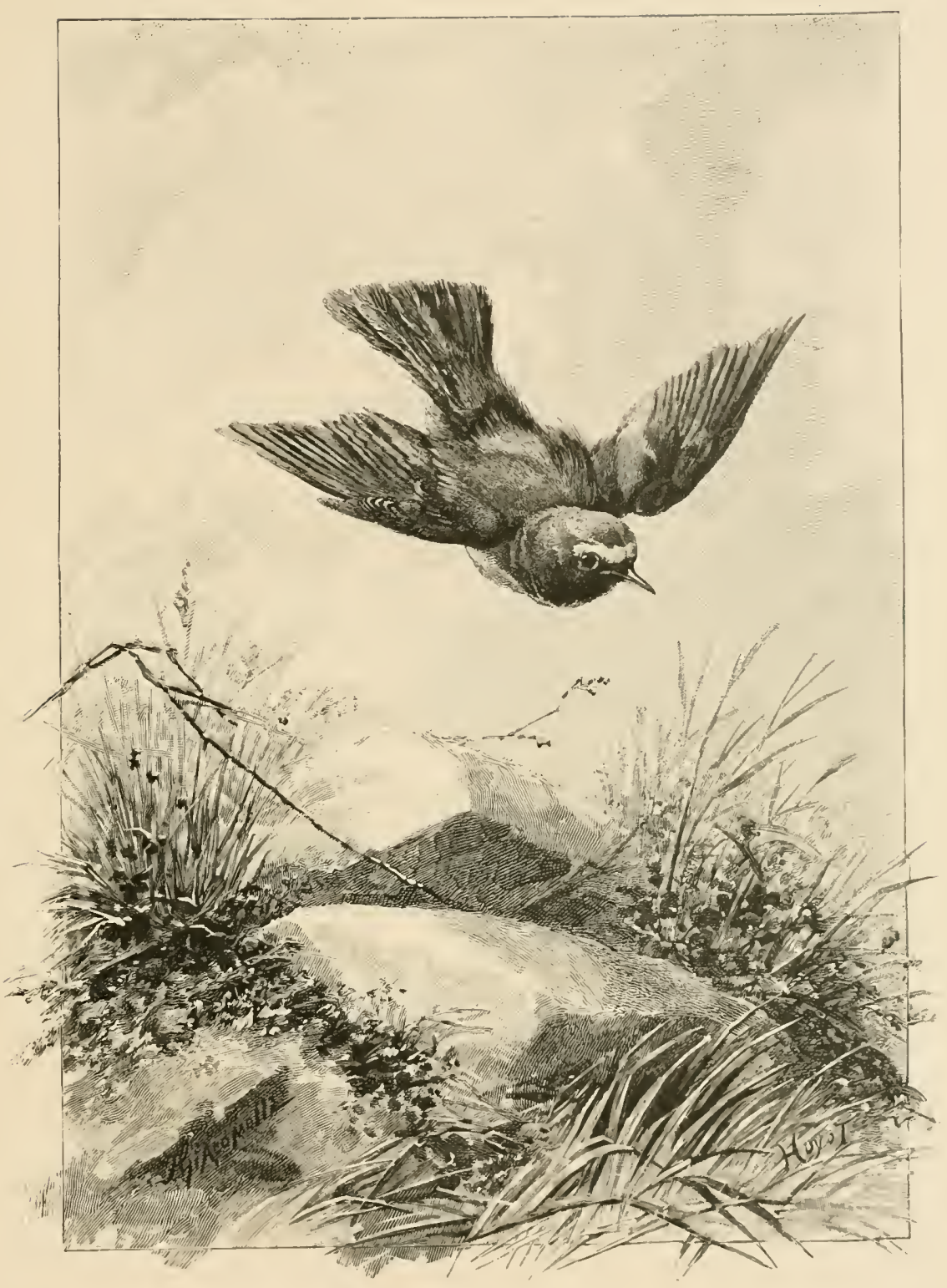

THE RED-STAR' 

about with quick movements, wide-awake eyes and turned-up tail.

The female blue-breast builds her nest in summer and constructs it of interworen grasses, generally kept together by the reeds and osier, in the midst of which it is built. At pairing-time, the male takes its flight upwards, fluttering and singing its strain. Then it descends, turning about with the agility of the warbler, and ever chirping and twittering it swings to and fro on some flexible reed. Its chirp is very sweet in pairing-time, but it turns into rather a rulgar cry as soon as the season of courtship and love is over. The young ones are of a blackish brown hue in the beginning; the delicate blue shade of the throat appears only later, after the first moulting, and it is even said that in grown birds this beautiful colour fades in a state of captivity.

As the summer wears on, the blue-breasts approach gardens and orchards where they find savoury fruit in abundance. The vicinity of man does not frighten them. They become familiar enough to be looked at and admired at leisure, whilst they are picking the elder-berries, of which they are extremely fond. Their taste for that juicy fruit becomes fatal to them and they are frequently the victims of their greediness. The ripe berries of the elder-tree serve as a bait for birl-catchers who use a bird-call and who set lime-twigs for them on the skirts of woods. In the province of Alsace and in the V'osges 
mountains, many unfortunate bluc-breasts are caught in this manner at the time of passange. Bird-catehers are without pity for their prettiness, without mercy for the rare, delicate shade of their breast, and they add this meagre prey to the chaplet of red-breasts, warblers and green-finches, which are destined to expire in the frying-pan. It is in an iron pan, called coquille, that the bird-catchers of Lorraine fry this delicious bird with tempting pieces of bacon, and compose a delicate roast that all epicures delight in.

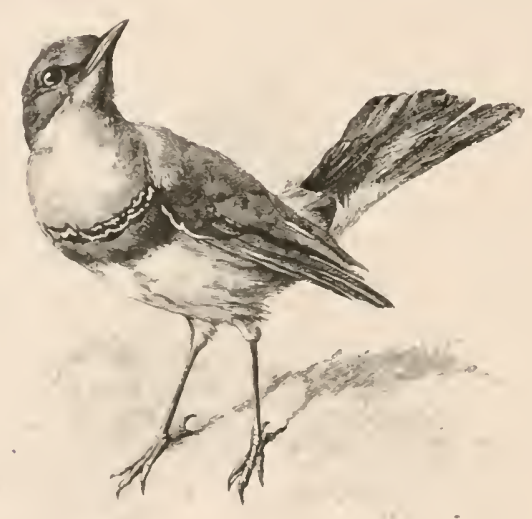




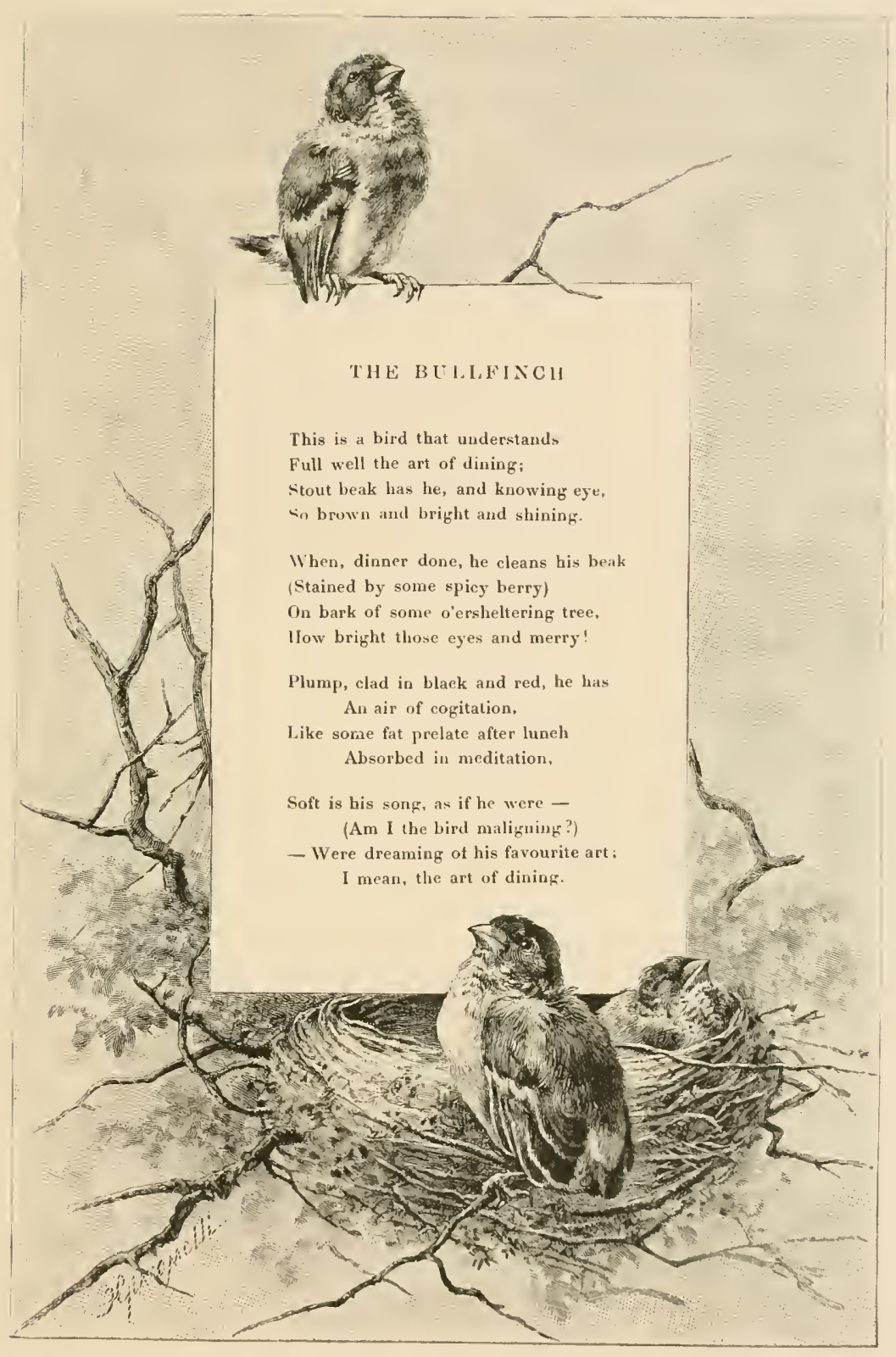





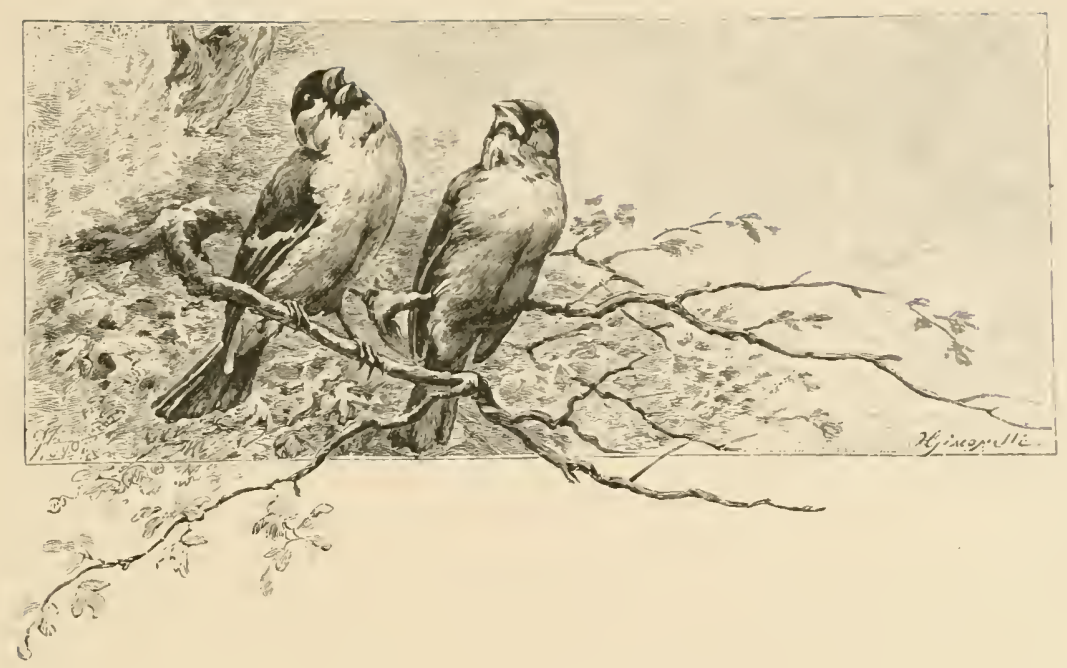

THE BULLFINCH

Spending a winter in the country, I had a bulfinch to keep me company in my retirement. It had been caught in its nest towards the end of the preceding spring and had had time enough to get accustomed to its bondage. Neither its development nor its good humour were any the worse for the domestic life it wals obliged to lead. It was of the size of an ordinary sparrow. Its thick, hard, black bill was slightly bent, its nut-coloured eyes had a lovely expression, and the colours of its plumage were as bright as ever. The top of its head, the outlines of its bill and the beginning of its neck were of a fine black lustre, 
which set off all the more the red tint of the throat, the chest and the top of the stomach; the nape of the neck and the back had ash-coloured tints, which contrasted beautifully with the light purple, red spotted wings and the dark purple of the large tail feathers.

It was of a merry mood and had the most remarkable musical aptitude. Left in freedom, the bullfinch is only an ordinary singer. It has hardly more than three notes: a very pure whistle, then a rather hoarse warble, degenerating into a falsetto; but the honest peasint who had undertaken the training of my particular bird, had succeeded, by dint of patience, in teaching it softer and more varied sounds. My bulfinch gave a penetrating accent to its short musical phrases, a certain softened expression, which charmed my solitude and made it dear to me. The winter was very severe. The snow would drift against the windows and settle there in white mounds; at other times, the west wind and rain storms would beat furiously andinst the doors and windows of my dwelling. Neither the bullfinch nor I cared for the inctemency of the season. A hright fire was crackling in the fire place; I had an anple supply of interesting hooks: my friend had abundance of hempseed, salad and hiscuits ; we spent happy days indeed in our small study, with its smoky crossbeams and its white-washed walls.

Excepting at hed-time or at night, my companion never remained shut up in its arge. The door of its 
prison was always open, and it took advantage of this to roam about the room, ever humming or singing. Sometimes it would perch on the pole of my bed-curtain. or it would settle near the window, rery inquisitive as to what was going on outside. There, in the muddy. snowy street, a peasant would pass by, heating the parement with his wooden shoes, or else a cart would drive past our house, splashing our window-panes with mud, and we could distinguish two or three peasantwomen between the stave-sides of the cart. squatting under their blue cotton umbrellas; or else, school-children would rush out of school, making a great noise and splashing in the muddy puddles of water. The bullfinch would consider all this with pretty hitchings of its head, and at times it would particularly express its interest by some light sounds: twi! twi! twi! Somelimes too, when I was completely absorbed in my reading, it would flutter about me and finally alight on my head, where it seemed to take great pleasure in disaranging my hair.

In the evening I went out generally for my dimner and usually came home rather late. As soon as the bullfinch heard me open the door, it would wake up) and was always sure to welcome me by a sweet chirping. This seemed almost to be a sort of friendly reproalch for having left it alone and having remained out so late. Then, having rattled out all its grief and sadness, it would put its head under its wing: I undressed and we both fell somndly 
asleep; but early in the morning, it was he who awakened me by a joyous greeting. The bull-finch secmed to invite me to leave my conch, to light the fire and to fill ils manger.

In this manner, we spent our winter most pleasantly ; Hen March and its storms and showers melted the snow; the first violets, daffodils, and sweet scented wood-ruft peeped out in the garden: we could now open our window and inhale with rapture the first bahuy breezes of spring.

Spring is the season when in our momntainous regions wild bullfinches begin to fly about in couples. They pair in April and huild their nests in hedges. These are male of moss on the ontside, of feathers on the inside; the female lays five or six bhuish-white egges spolted with violet on this soft bed. When the young ones are hatched and sufficiently feathered, the father and mother take them across the country, sometimes to blooming vines. sometimes to orchards filled with cherries, or else they fly about the skirts of a wood. The whole family leads this sort of ragtant life until the latter end of autumn, picking at ears of corn, devonting the fruit of the sloetree, as well as hackberries and tog-wood, disbudding aspen-trees, alders and sorbs; whistling, calling and answering each other, intoxicating themselves with air and sunshinc.

I do not know whether my bullinch (a male) had a 


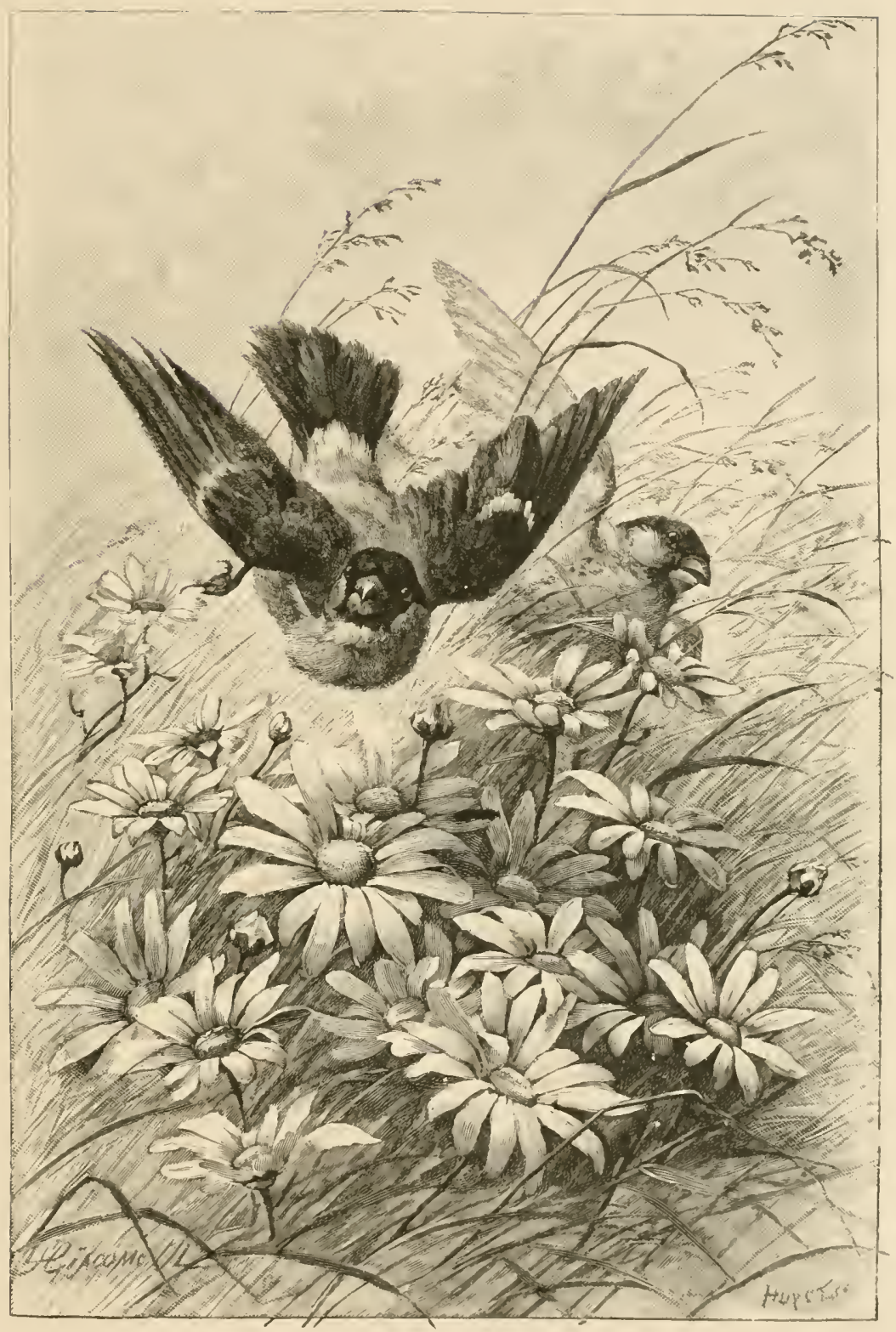

THE BULLFINCH 

vague sort of inner presentiment of all these things, but as April was making Nature green and the air was getting warmer, it became more restless and more turbulent. II would leave its cage more willingly, fluttering impatienlly about the room, hanging on the window-sill or beating. lightly against the panes with its bill.

Surcly some mysterious instinct had been telling my companion about the budding hedges and the free bullfinches who were making love to each other in the pleasant sunlight. It cared no longer for its food, although it was generally very much of an epicure; it disdained its lempseed and hiscruit; it had only one ohjert in view : the window; it would spend hours there as if in a drean, looking at the trees, whose new leaves the wind was shaking. and which appeared just above the opposite wall beyond. Then another fit of frenzy would seize it; it would pick again at the window-panes, repeatedly uttering a low cry which secmed to say: Why do you not let me out? Why do you not let me out?

One fine morning, finding the window ajar, it flew away while my back was turned.

Daraled at first by the sunlight and not accustomed to the open air, it did not fly far. At a distance of a few yards from the house, there was a heap of manure in which about a dozen hens were scratching. There the bulllinch halted to make use of its liberty by hunting for worms in this fruitful ground. But it had not counted on the in- 
tolerant, quarrelsome disposition of these shrews. At the sight of the intruder that came to pilfer on their estates, the hens flew into a great rage. In a second my poor bullfinch was surrounded, worried, picked at and plucked by their sharp bills.

Leaning out of my window, I had followed my fugitive with my eyes, and I understood the danger it was in. I jumped out of the window, ran to the spot, but it was too late. - Bruised, plucked and bleeding, my poor little companion lay motionless on the dung heap, whilst those harpies were yet worrying it with their bills; - when I succeeded at last in pulling it out of their clutches, my poor bullfinch was dead.

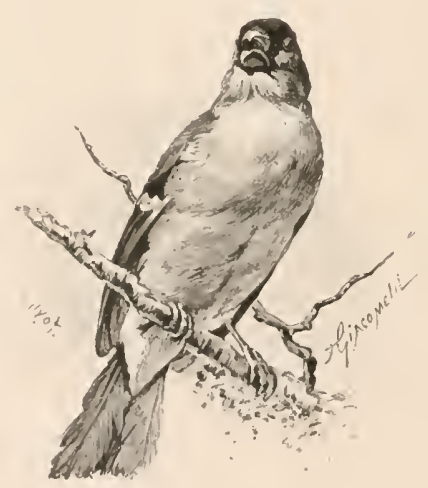




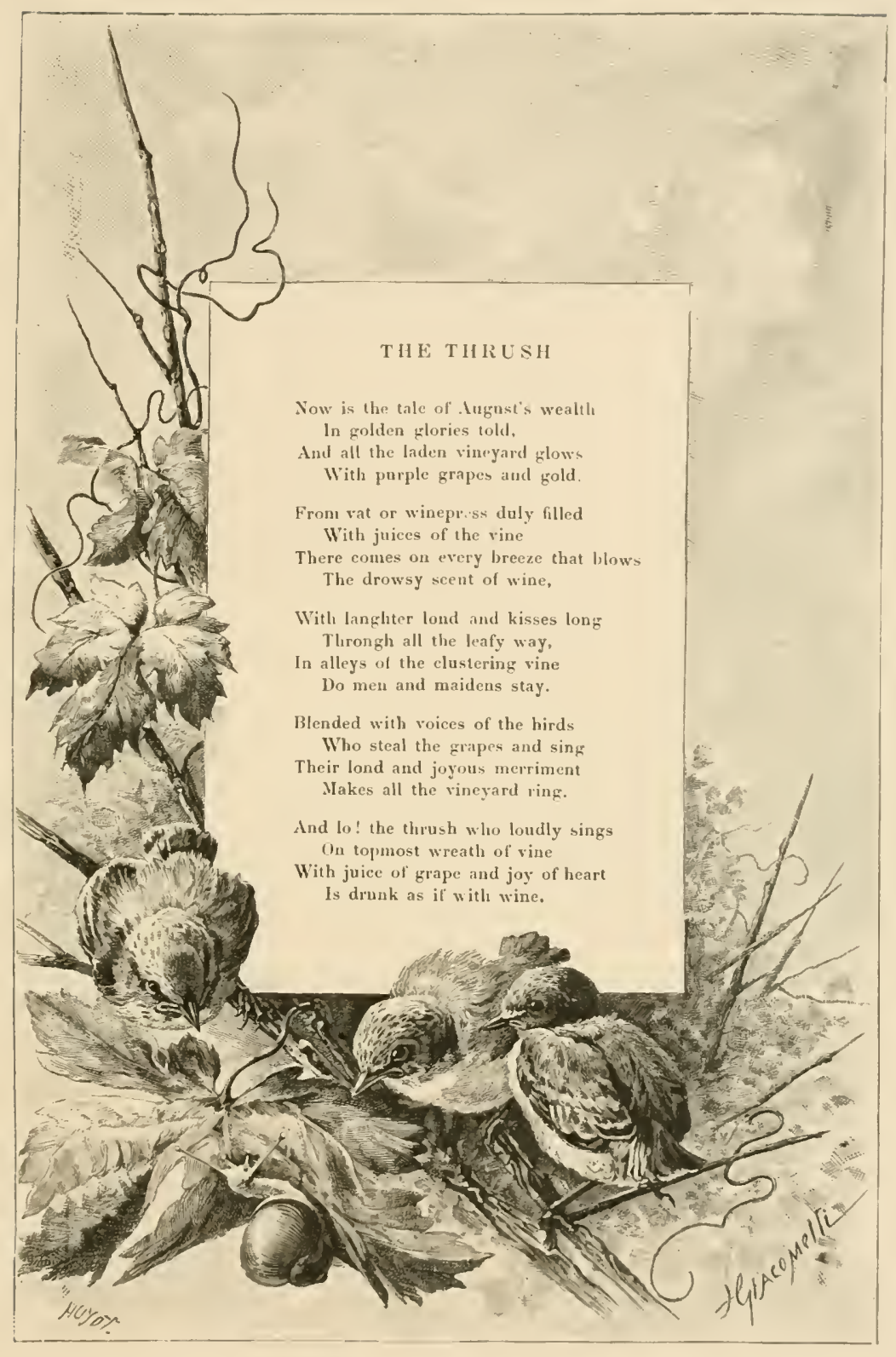





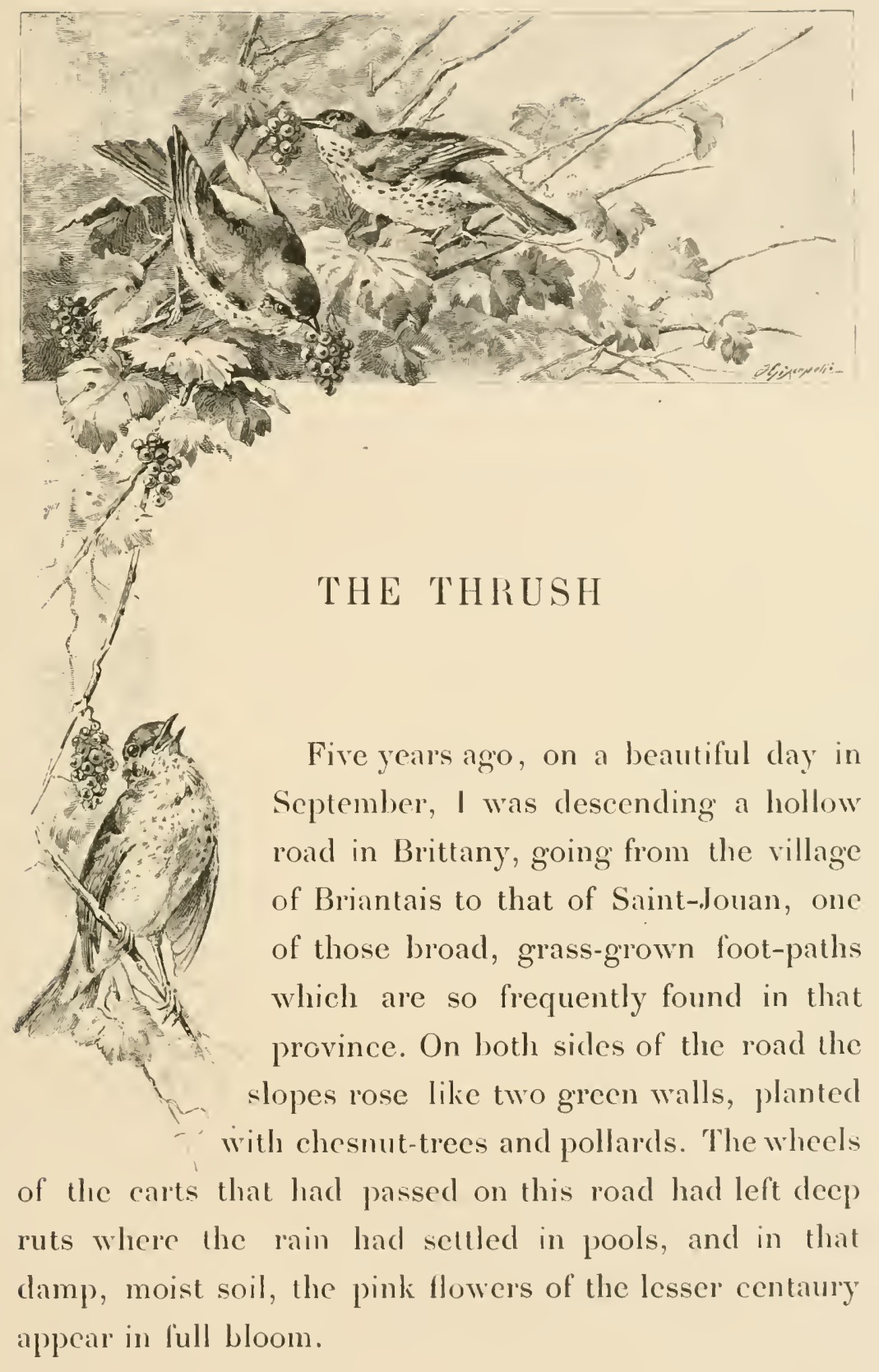


It was perhaps eight riclock in the morning; I was listening in the balny frestuness of early autumn to the parish bells ringing for mass, whilst thrushes were singing in the juniper trees of the moor. At the same time the salt hreezes that blew from beyond the sloping declivity tolel me the sea was near.

I was just about climbing over a fence made of boughs when I heard some steps behind me, and turning round, I perecived an early riser who was fond of walking, coming in my direction. He appeared to be about thirty ; he was dressed in a suit of dark blue cloth, wore a round felt hat and looked like a well-to-do comtry gentleman; his dress was cren too claborate for that early morning hour, and his deawn features. his eves circled with black. his hooked nose pinched at its extremitr. his leady complexion, all seemed to indicate that he had passed a slecpless night. Not being very well acquainted with the topogaphy of the locality, I cook advantage of this unexpected mecting to ask him whether I was on the right road to Saint-Jonan.

He answered in the affirmative and told me he was going the same way himself, adding" " I shall be happy to show you the shortest way, as I am going home and anxious to get to bed n.

IIe noticed doubtlessly an expression of surprise in my face, for he added smilingly : "You are astonished that I should gro to bed when others rise? It is quite 
natural; I spent the night at the Casino of Saint-Mlalo: the game of bacearat was very animated, and we only left the gaming table at early diawn n.

I considered him more altentively: he had indeed the countenance of a gambler. Ilis grey eyes were glistening feverishly and contrasted with the impassibility of the rest of his fealures. Is we were walking along, a thrush began to sing. The grave notes of its song altemated with low, chirping, shrill flourishes: my companion lifted his head suddenly and listened to the familiar strain.

"That's a young thrush », muttered he, "al prelly hird, my good sir! it is clearing its throat with the firuit of the juniper-tree and that softens its roice. I am fond of hearing that song on the moor..... It is a fetich and it brings me good luck.... If I had heard it yesterday when I was going to the Casino, I should perhaps have had better luck! But instead of that I am going home completely plucked. - Fortumately I am not easily discouraged and shall make "1) to-morrow for to-day's ill luck!"

The thrush continued throwing its trills into the air, and the gamester, standing on the grassy declivity, stopped again to listen.

"I know that particular hird, said he: it has huilt its nest on the lower branches of an oak-tree: I ranght it the other day brooding, for with these birds, it is the male who broods, so as to let the female rest! It is a most 
excellent father and husband! " My companion sighed again. "I noticed this thush ", he continued, " on account of its black eyes and the orange coloured tint of its wings: these two traits distinguish it from the red-wing or wind-thrush. Just as I was bending over the nest, the bird flew away; - I ought not to have startled it, it has brought me ill-luck! ")

Wre had now reached the entrance to a long avenue of beech-trees; at the other extremity of which we could percecive the gate of a manor-housc built in the architectural style of the time of Louis XIII.

" This is the road that leads to Saint-Jouan ", said my companion, " and l am now at home. Good morning to you, my dear sir ! "

II e separated, and I saw him disappear slowly under the shady arch of the beeches. - M Saint-Jouan I questioned the inn-keeper about him and I heard that the avenue of heerhes led to the manor of "Lat Crochais ", belonging to a certain $\mathrm{M}$. de Trelivan.

'The following week at the Casino I again met the owner of "Is Crochais n. Ile was silling at a berecuret bable and bolding the hank. While dealing he was biting his lips and deops of prespiration were standing on his brow. I quarter of an hom later, he gallered up what he had won, picked "Ij) a pile of gold and rose from his seat. He recognized me immediately and (ame up to me, saying: « It's all right, I am maling up for my losses of the 


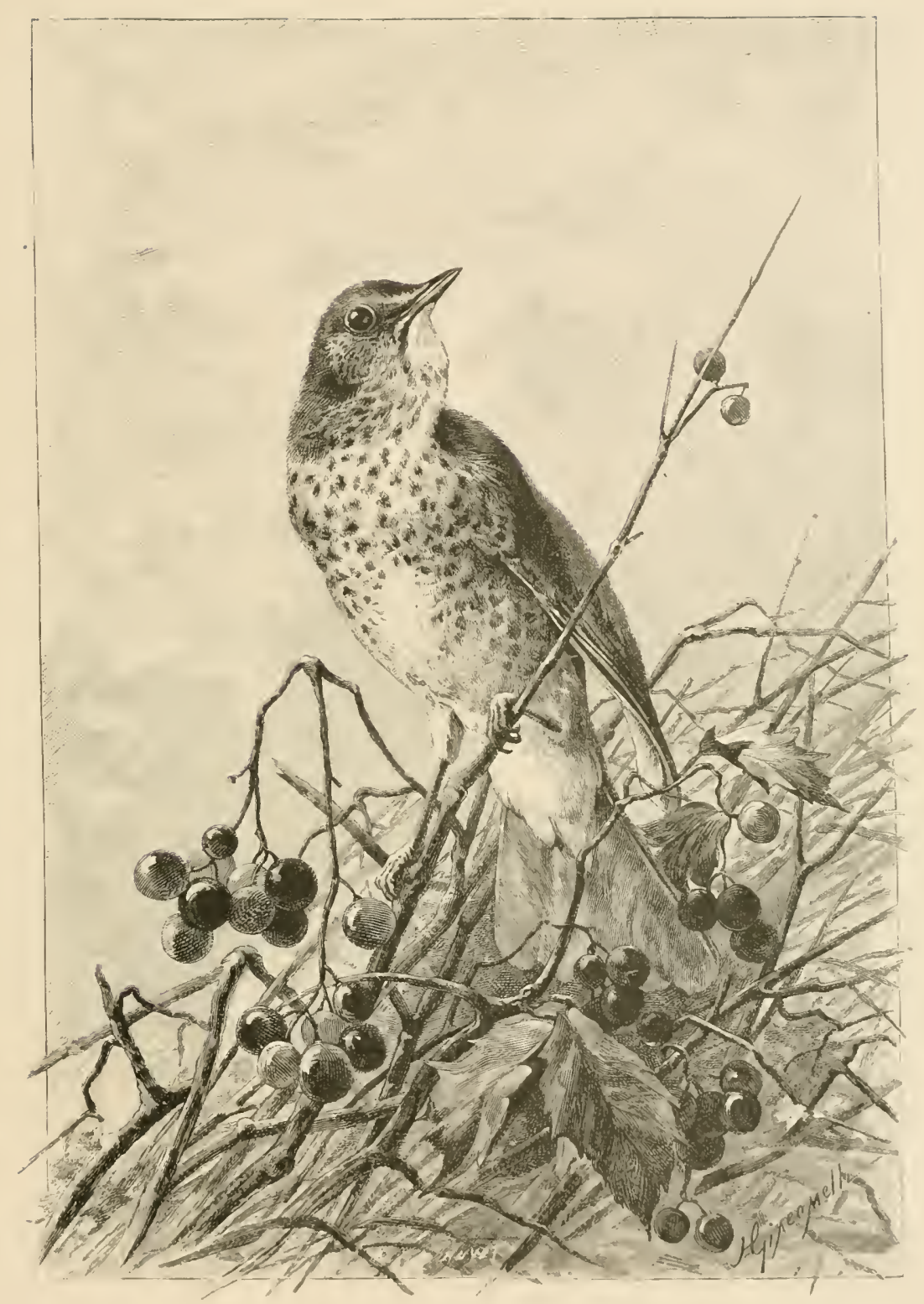

THE THRピU 

other day. ... You see, it is necessary not to give in.... and besides, added he in a low roice, I heard the thrush singing on the moor this evening, its song was never merrier. It's a pretty bird, sir! While I was listening to its song, I was saying to myself: "I shall have luck to-night! » and so far really, I have no reason to be dissatisfied! ”

I left Saint-Malo on the following day. I rame back this year, and the other day took a drive to Dinan, following the left bank of the Rance. On the road, one of the bolts of the pole of my carriage laving dropped, we were obliged to halt going down hill. "Fortunately there is a farrier at Saint-Jouan ", said the driver" : if you would be kind enough sir, to walk as far as that, it will take only five minules to have the pole repaired m.

The name of Saint-Joum awoke a slumbering recollection in, my mind. I recognized the landscape that I had perceived years ago : the avenue of beeches, the slatecovered roof of the manor, huried in the shining verdure of the chesmut trees, and the moor where the thrusheswere singing as formerly. 'To the left of the road, at a turning, I noticed a grey granite cross erected on a low hill; above this cross maple trees were shaking their silvery leaves. "Is there any one buried here? ) I asked of the driver.

"Yes sir", the owner of "La Crochais ", that manor on your right, a certain M. de Trelivan n. Trelivan! the name was sufficient to bring the past back to my mind. I saw again before me my companion of yore with his robust 
frame, his erect carriage, his fererish eye, stopping on the moor to listen to the song of the thrush.

" lle blew out his brains on this rery spot, sir, continued the driver, you see he was a gambler; he had just lost some cnormous sums at the Casino, and had a wife and children. One morning, as he was coming home, he sat down yonder, facing his arenue, and blew out his brains! I great pity, to be sure! a magnificent looking man, and so merry when he had good luck! Sometimes, when I drove hum to Saint-Malo, he made me stop on the road to listen to the thrush. He used to say that it brought him luck! It must sure!y be, that the thrush had'nt sung that morning! )

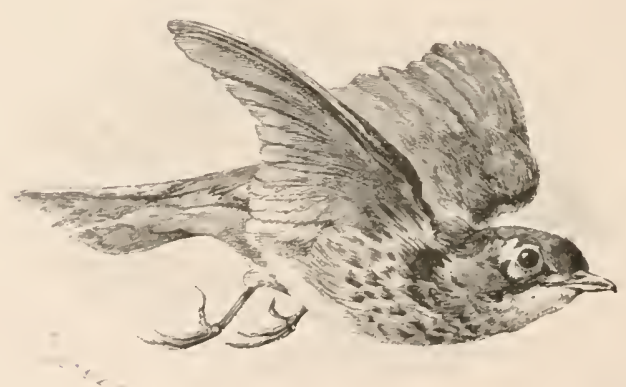




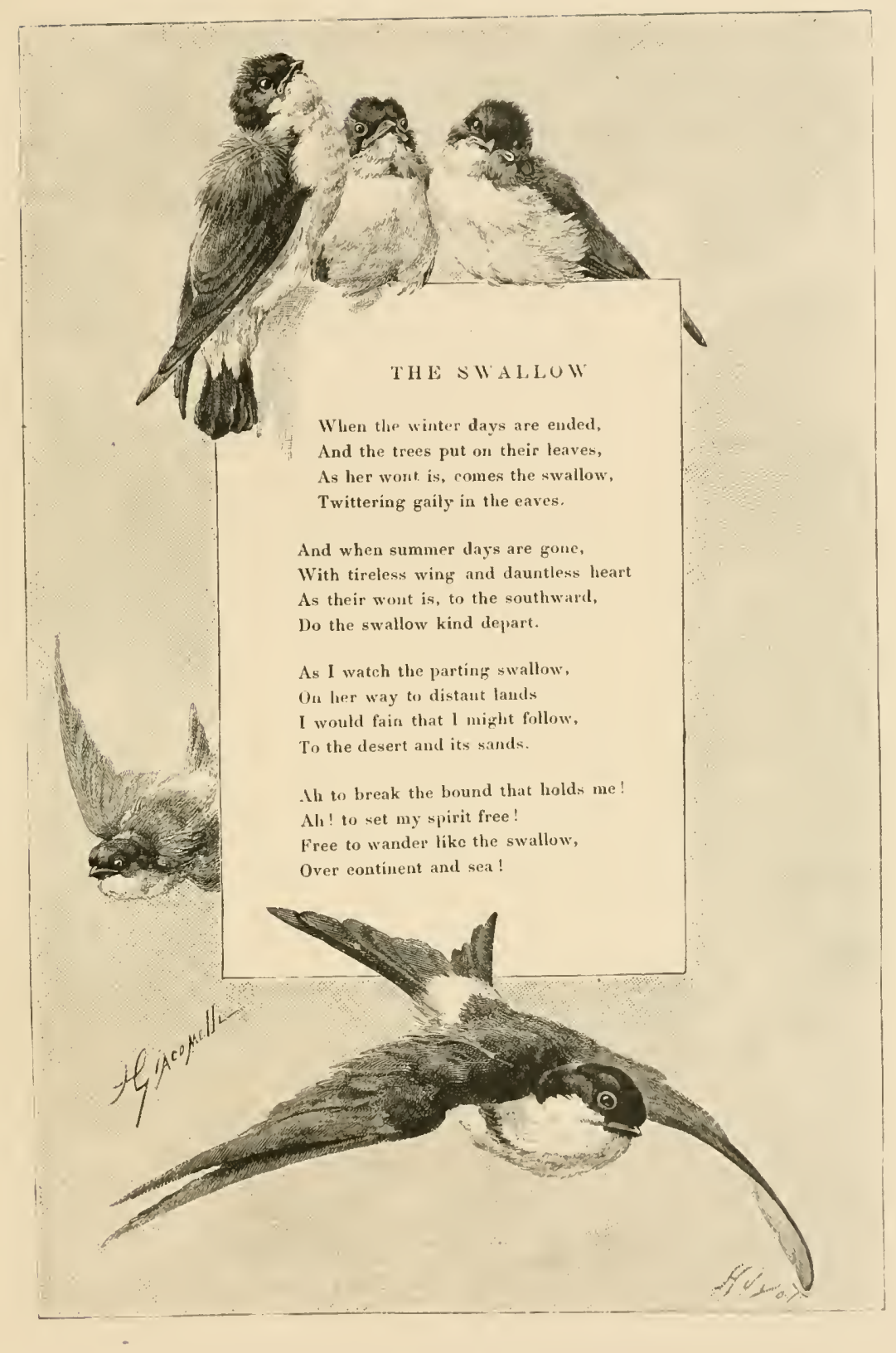





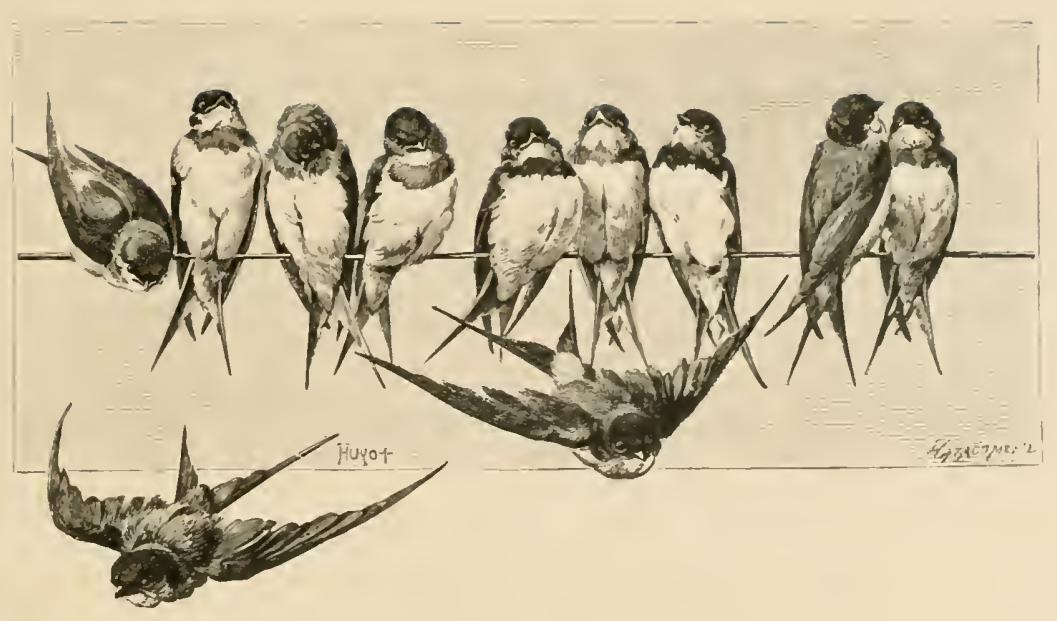

THE SIVALLOIV

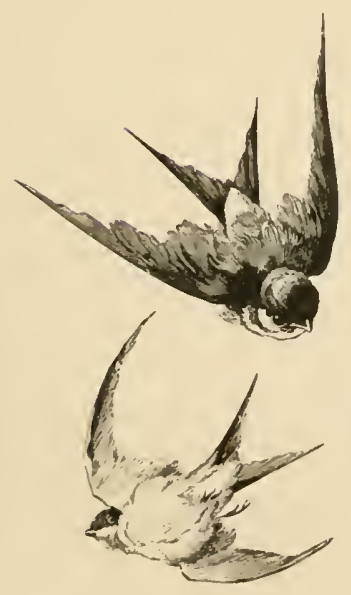

I remember one evening having witnessed the departure of swallows from a corner window, looking out on the solitary small square of a country town. One of the sides of the square was entirely accupied by an old mansion; its balconies, cornices and friezes offering numberless resting places to the future travellers.

During the last few days I had noticed an unusual coming and going among the swallows. They were flying about restlessly, with a very busy look. Some would dart down the whole length of the street, describing long cir- 
cuits, throwing out cries of appeal, then reappearing at the other end of the street, bringing up many new-comers, which like quarter-masters, would inspect every corner and then disappear likewise. Every morning the hand in(reased ennsiderably. You would have thought they were experimenting on the preliminaries of departure, and that the messengers had been ordered to indicate Io all the place of final eongregation.

Evidently the collective departure of these birds necessitales a number of private meetings and an agreement prepared long beforehand. Even if we admit certain mysterious presentiments, it would be absurd to believe that instinct alone, so to say mechanical, conld make all the swallows of one region congregate together at the sime time and the same place. This displacement of a whole population of birds can only be explained by a series of rather complex reasoning and by a special sort of language, establishing prompt communication between individuals of the same species. Who assumes the responsibility of the meeting? who chooses the hour of departure and the place of congregating? Probably the clders of the tribe, those who have had most experience.

It is well known that swallows eome back faithfully every year to the same quarters and the same nest. Therefore, there must exist in every borough, in every town, some old patriarchs well acquainted with all variations of climate, with all local resources, with the 
roads to be taken, and who, having the presentiment of the coming hour of migration, will agree about the place of meeting; then, they will disperse in the coun try all around, to inform the whole clan. Many naturalists noticed long ago that swallows have a peculiar cry for the circumstance, which they call "the cry of assembly ».

These preparations interested me exceedingly. I could watch them from our garret window, where precisely two swallows had built their hemispheric nest of straw and gravel, which they regularly occupied every year. I had witnessed the return of our guests for the last three years, having watched intently the process of brooding and the training of the young ones. Once even, after having read a book on swallows, I had caught one of the parents by means of a net spread over the orifice of the nest and I had tied a green silk string to its foot. How happy I was the following spring, to see in the nest the same swallow having yet a bit of the green thread tied to its foot! This cireumstance redoubled my interest in these birds which had come back from afar to a dormer window in our humble dwelling !

Swallows had for me that marvelous attraction that draws us towalds people who have travelled in foreign countries. Their return was a sign of coming spring; their departure always left me with an aching heart; it told me that the end of my holidays was drawing near.... 
Emotion mingled with regret, as if I were witnessing the last act of some pathetic tragedy, while I was watching their last gatherings.

During these prepalatory evolutions the power, the strength and the elasticity of their wings seemed to have increased. It was a delight to see their fluttering in the open air. There they displayed all the resources of their art of flying: turning and turning about again and again, changing their direction at every minute and exercising themselves to soar high in the air. You conld see that having to accomplish a long sea-voyage, they enconraged each other and tried the strength of their wings, so as not to carry any straggler's with them. It is even probable, that, if during these preparatory exercises any swallow had revealed some weakness of constitution, it would have been pitilessly left behind. Besides, this is the manner of proceeding of all migratory birds that travel in flocks. - An Austrian officel told me that he had seen storks congregate together on the wide plains of Hungary at the minute of starting. For hours they would describe long circles so as to put their strength to a trial. If one of the storks, too old or too ill, lost its strength and dropped down, immediately the whole flock darted on the poor creature and killed it pitilessly.

No such tragic event accompanied the departure of my swallows, and I had no such execution to witness.

One September afternoon, I saw them arrive in great 


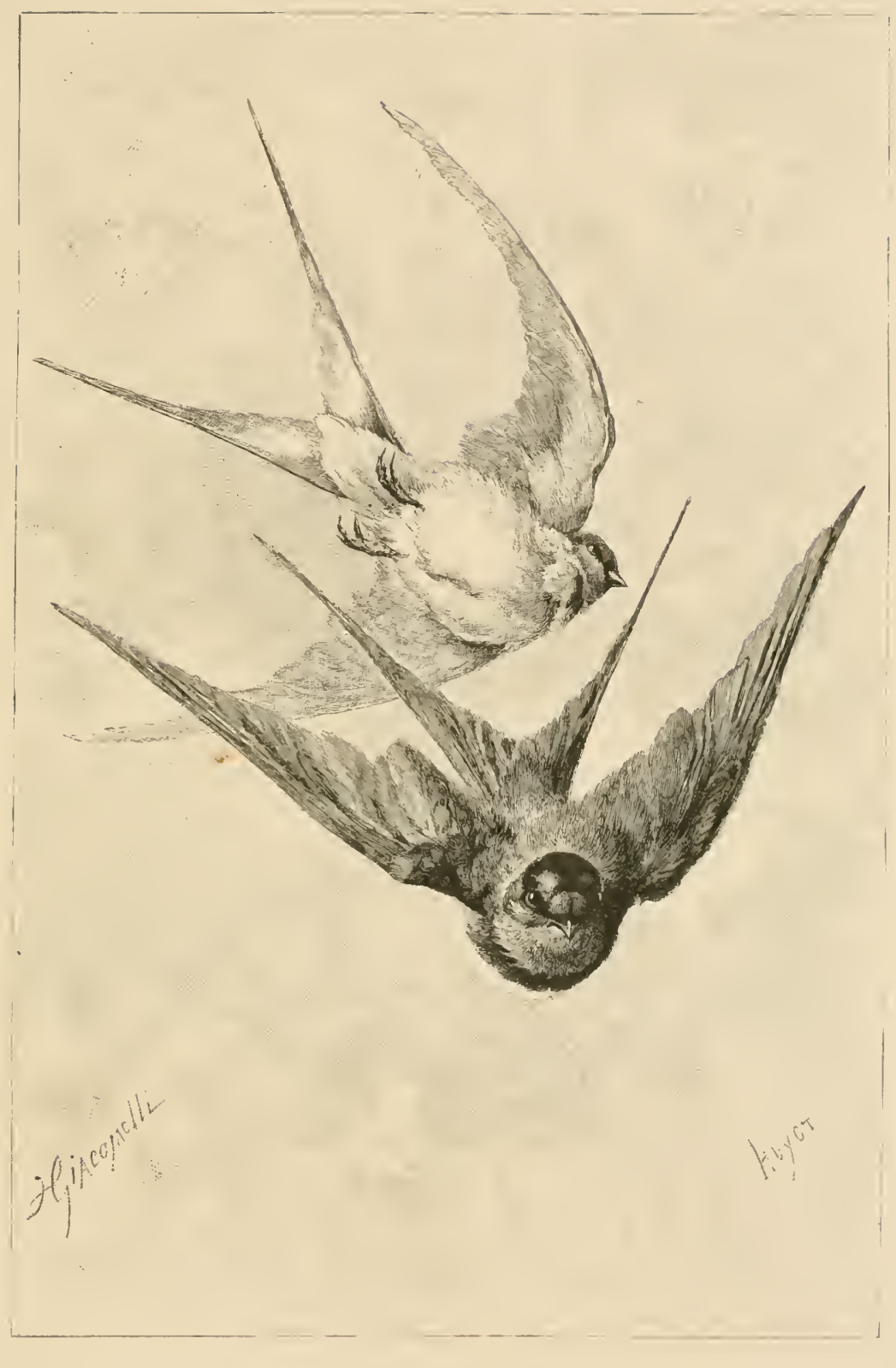

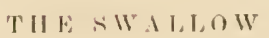



flocks in the square. The weather was fine and grape gathering and vintage had begmn. Merry sunshine was bathing the dew-covered roofs and at both extremities of the street I could perceive the vine-covered slopes of our hills. From all the streets near by swallows were issuing. They would turn a minute in the sky, then they would perch on the window-sills and cornices of the houses. The supports of the balconies and the friezes were soon covered by a long line of small black heads, nodding softly with low melodious chirping. Now and then, one swallow would leave the line and at a single flight would survey the front of the ranks, as if to make sure that every thing was in order and the troup complete. No, not yet. At every instant stragghlers were coming up hastily; they were received with impatient cries from the birds of the flock; then, with yet more noise and tumult, they would draw up closer so as to make room for the new-comers.

After a little while a profound silence began to reign among the flock - an almost solemn silence. The sun was already lower down and sending oblique rays into the street; the shadow of the hills was lengthening on the town. Suddenly, at a single flight, the troup of swallows took wing and ascended, their wings fluttering and quivering with confusion and agitation. For one second the sky was darkened by this black battalion hovering above the square; then the swallows, forming 
a long winding line, look their flight towards the south and disappeared in the mists which overeast the horizon.

When I turned my eyes again to the ground, the whole town appeared to me sad and lonely. I remained a long while standing at my window; thrilled with that sensation of sadness and solitude which follows the departure of those whom we love

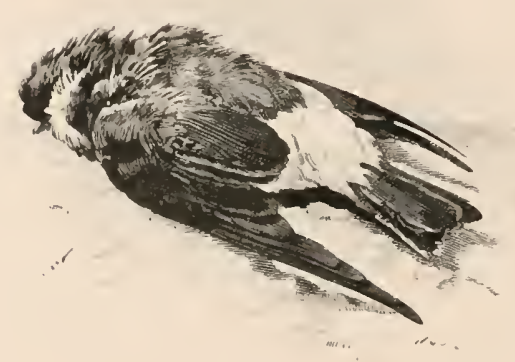




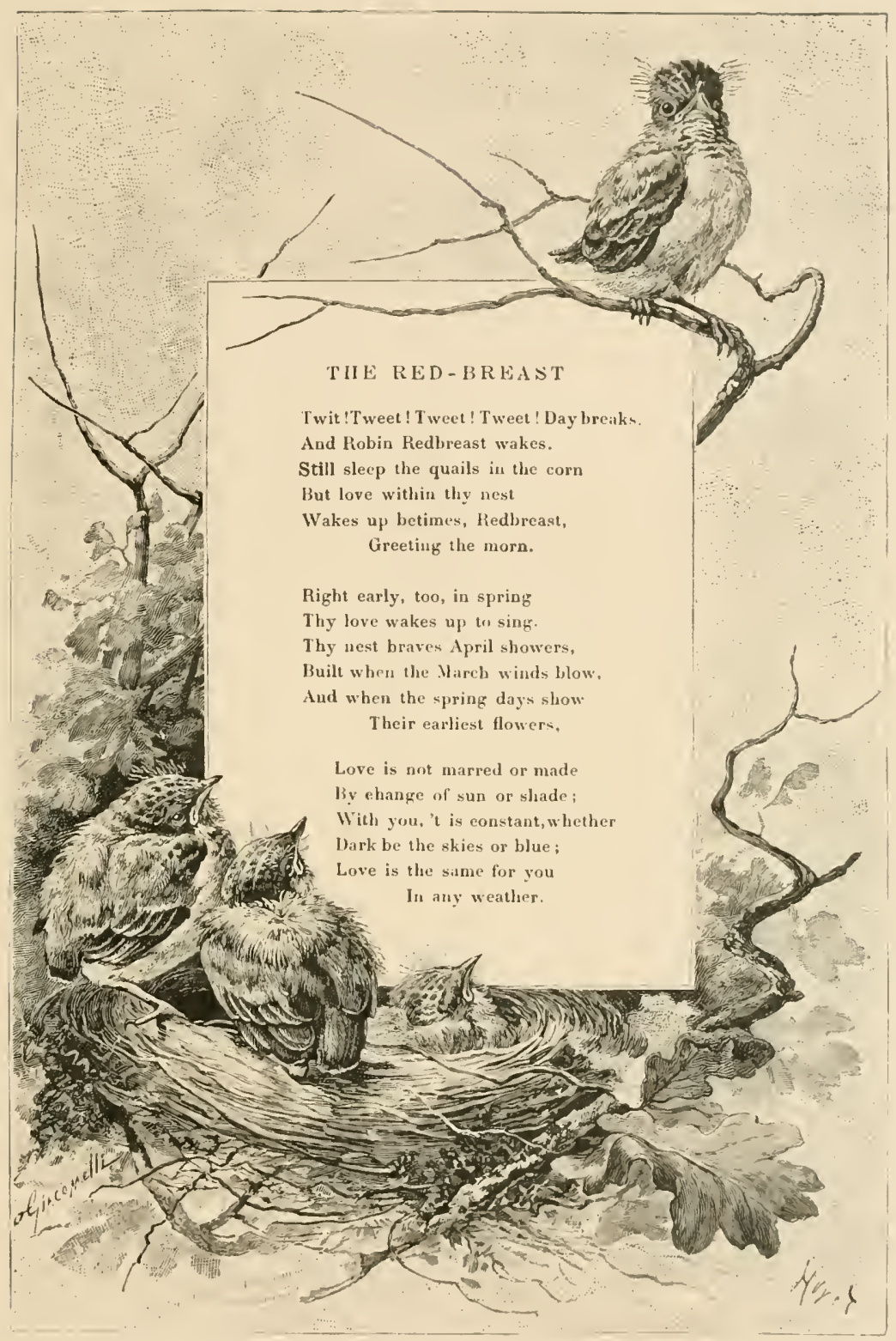





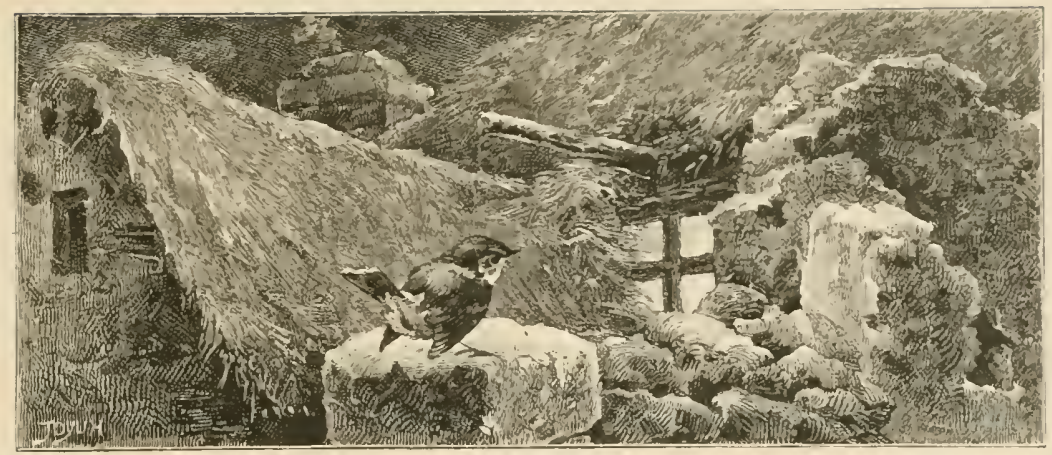

\section{THE RED-BREAST}

Thomas Carlyle used to be fond of relating that in the beginning of his career he had been obliged to live a long time in the turmoil of a big eity, where he had met with nothing but annoyance. One day, as he was coming home, morally worn out and discouraged, he suddenly heard a band of larks sending up their joyous strain from the corn-fields. just as he had formerly heard them chirp in his father's farms: this unexpected music then checred him greatly and gave him new courage to fight the battle of life.

This evening, I have had a similar cmotion, sweet and yet melancholy, while I was listening to the song of the 
red-breasts in the beeches of a neighbouring park. Birds have that peculiarity of always appearing to be the same that we have heard before. Years pass away, we grow old, we see our friends die or disappear, we sec revolutions change the face of things in the world, our illusions vanish one by one, and yet, in the trees of the orchards or the beeches in the woods, the birds that we have known in childhood repeat the same melodious call, modulate the same musical phrases with the same voice, apparently as young as crer. Time never seems to touch them, and as they hide out of sight when they die, as we never witness their agony, we can easily imagine that we are yet in the presence of the same songsters that charmed us in early youth.

Be that as it will, the red-breasts to which I have been listening to-night were warbling their song with the same tender and caressing expression as when I was young. They were skipping about merrily and familiarly quite near me in the reddening branches, and I could dislinctly perceive their bright black eyes, their brown heads and their breast with its beauliful reddish orange tint. The aspect of the bushes, covered with blackberrics, the particular scent of the woods at the latter end of autumn, the charm of the beautiful red tints of that season of the year, added to the hallucination. I thought that the golden days of yore had come back, when, during the summer holidays. I would lie on my back. 
stretched on the grass on the outskirts of a wood, building magnificent castles in the air, whilst listening to the appealing cry of the hirds of passage. In those days, I would dream - my heart beating joyously all the while of my coming youth, of the smiling perspectives of the future, whilst the red-breasts, with their song, were warbling an approving accompaniment to my reveries.

To-night, I hear them again. The setting sun is just as magnificent - and yet its splendour is not quite the same as of yore. The tints and outlines of the landscape seem to be veiled with some melancholy mist. The time of maturity has come with disillusion, bitter experience, thwarted hopes. At half a yard's distance, there where the water is greenish in the cisterns, a red-breast was singing, perched on a wild rose bush above my head. The bird was looking at me familiarly with its areh black eye, secming to say to me:

" Well! old comrade, you have indeed grown old! " You, you are ever the same, oh friendly red-breast ! Your breast has yet that fine colour of ripe sorl to which you owe your name! At early dawn, you awake, you, the carliest riser among birds, and sing your melodious tiveli. All day long, in the depths of damp woods, you are searching for food under the dead leaves. On SaintAlbin's day, when the meadows are yet covered with hoar-frost, you bravely select the place of your future nest ; you begin to warble, in order to charm your mate, 
and as rour heart is as true and as faithful as it is wam and passionate, you have not many deceptions in love. In the warm nest you have woven of moss and grass, your large family is slumbering peacefully; when you leave your dwelling to search for food, you cover the entrance of the nest with a dry leaf, like a prudent landlord who closes the latch of his dopr before going out, and you take wing with a quict mind, having no care and no uneasiness.

When autumn comes, and haw, sorbs and dog-wood redden the hedges, you change your bill of fare, and you begin to live on juicy. perfumed fruit. Your throat then aequires a fresh suppleness, and your song new beauty and power. Leares fall from the trees, but the first colds of winter will not frighten you ; you will only fly nearer to human dwelling's. It seems that you regret to leave us, and often, in the month of November, the first soft snow will take you by surprise, and you will hammer with your hill against some bright window, asking unceremoniously for shelter and food.

To be sure, you do not escape the common lot, and you will grow old just as we all do; only to us it does not scem so, and we do not perceive that you are changing. IV e see red-loreasts hopping and skipping about at the same places as formerly; we hear your autumnal song, and it secms to us that we are yet hearing the same bird. 'They say that you are spared the decrepitude of old age, and 


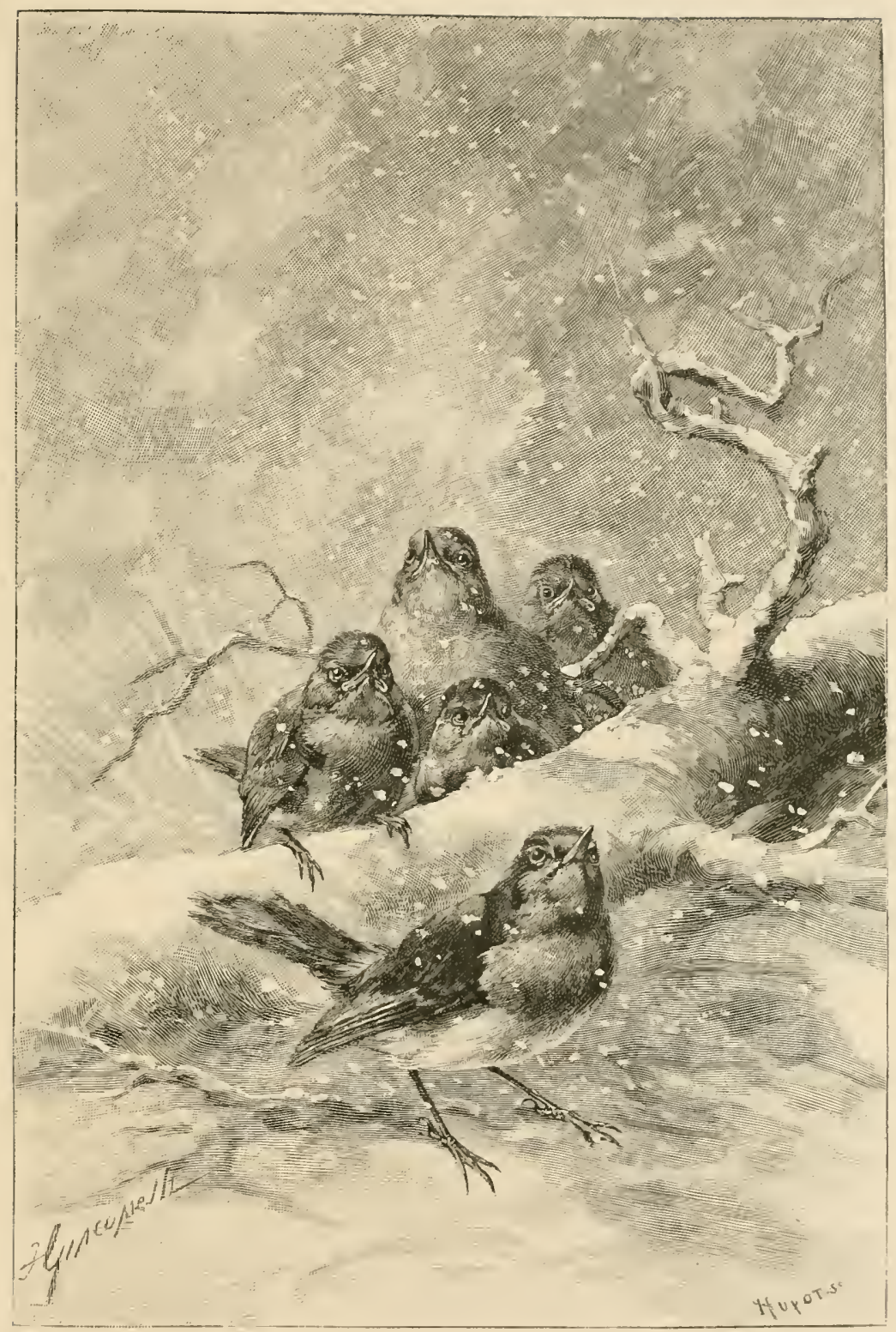

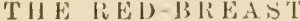


that generally you die suddenly, struck by a fit of apoplexy. That is another of the privileges of your destiny. As Montaigne says : "The deadest deatlis are the best. " On some evening in spring or summer, after too substantial a meal, or too long a feast of love, you will receive your death-blow. Dead leaves will cover your small body, just as they formerly covered your nest, and dying, you can still imagine that you are lying in your cradle.

Our lot is not so happy as yours, oh robin red-breast! Our life, less uniform than yours, is fuller of deceiving complications.

$$
\text { ...... A changeful infinite }
$$

It spreads before our eyes like sume vast plain Where firiry magic spreads for our delight The varying witehery of its mystic train.

There may we roam, loo, lost in wondernent, To choose among the myriad opening flores's: Amazed with beauty, afir, we miss lhe scent Of buds already grasped by hands of ours.

But although our life be interwoven with honeysuckles or briers, although it be entangled with numberless black threads, amongst which glisten just a few golden ones, it must yet finish like thine, ol robin red-breast! not quite so suddenly perehance, with more ups and downs, with a more lingering old age.... nevertheless, it must come to an end. Like thee, we must sleep in the dark earth, and nothing will remain of our individuality, of which we 
were so proud, but a remembrance, which lasts more or less and disappears entircly as years roll on. For a short while our friends will speak of us with a tear and a sigh ; then all regrets will vanish. Those who have wept on our grave will be consoled, and then disappear likewise, and insensibly and silently forgetfulness will heap dry leaves over our individuality as over thine! All will have forgotten the way to our grave. but butterflies and the birds of the skies. It will be a lucky chance indeed, oh robin red-breast, if one of thy brethren will come to warble there his friendly strain, the self same song, ever young and ever beautiful!

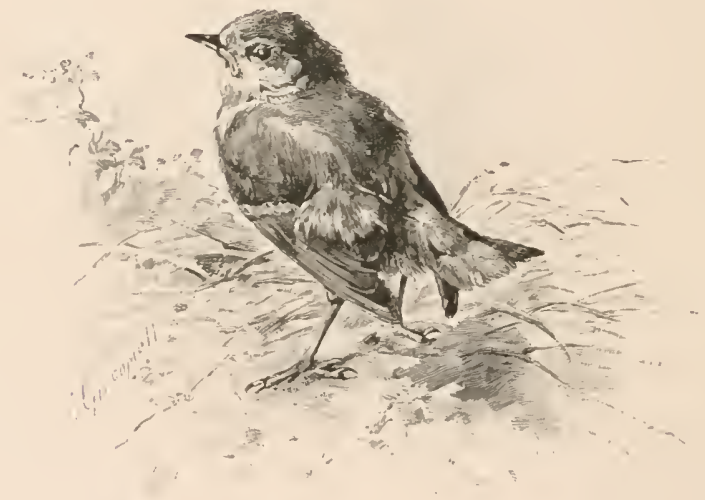




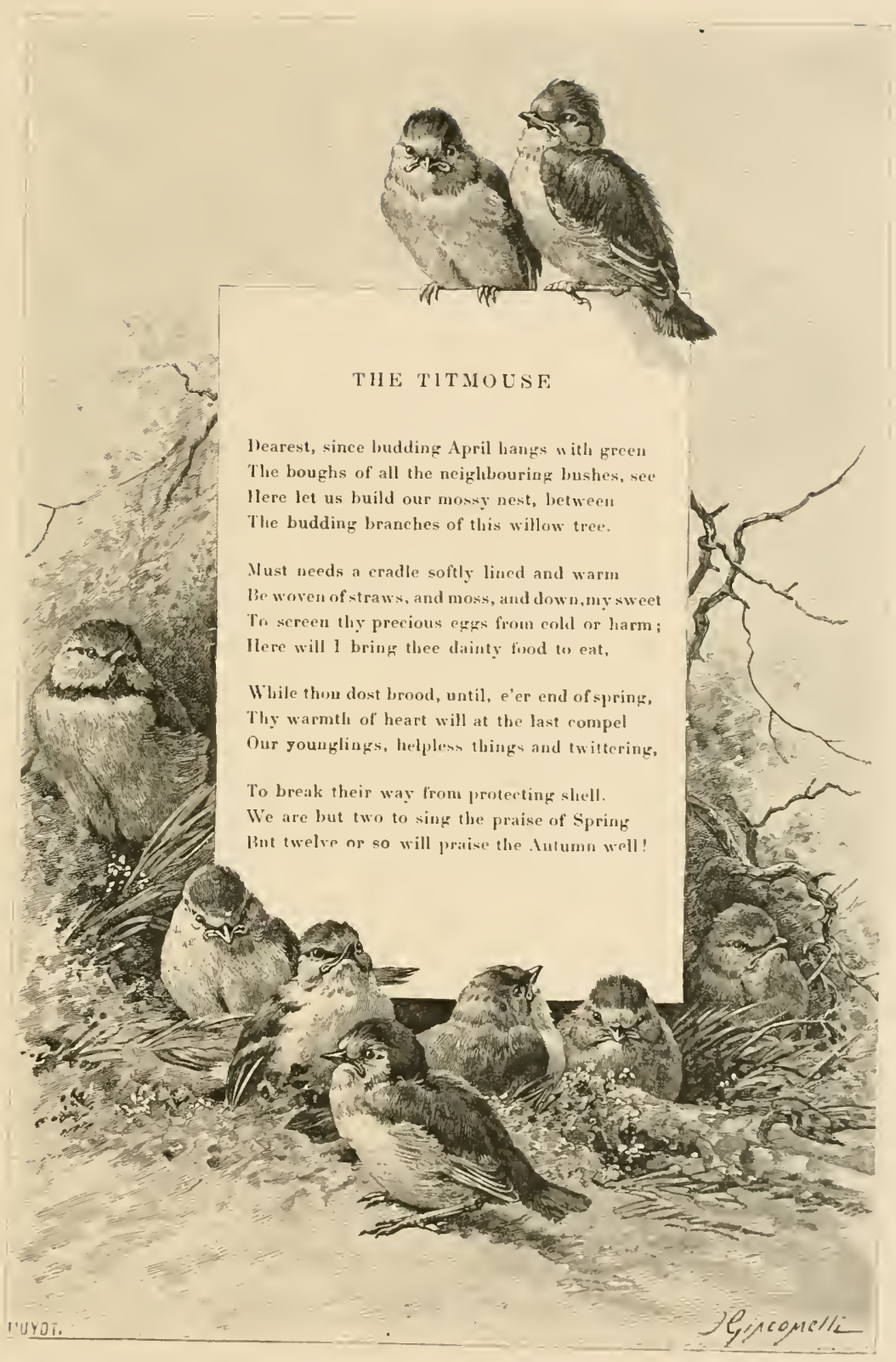





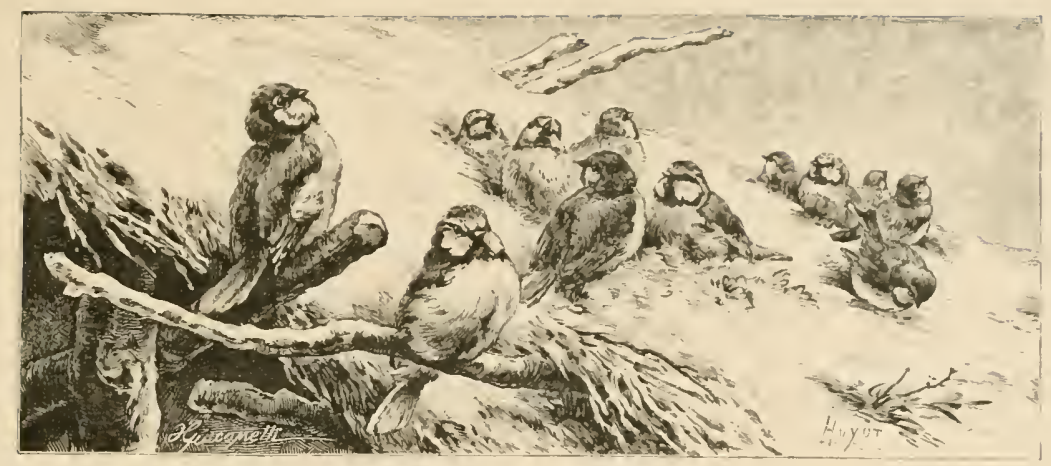

\section{THE TITMOUSE FAMILY}

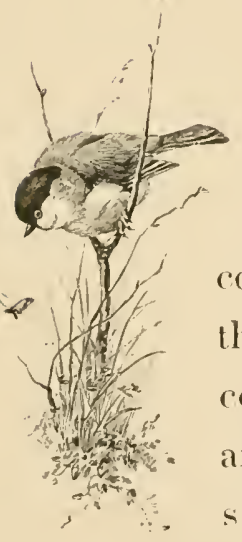

During the first rainy days of October, when windows however yet remain open, I could hear the low wabling of the titmice in the pines and firs of the garden. They had come there in troops ever since Michachmas, and they were actively engaged in picking spindle-trees, yews and larehes. Ever alert, they flutter about from one group of trees to another, skipping on the branches, turning the leaves, climbing along the hark, suspending themselves with their back downwards, so as to be able to pick more easily the crevices in the bark, where they know that worms and insects hide their chrysalis.

All these titmice differ in colour, size and general 
appearance: still they offer certain general characteristics which do not allow us to have the slightest doubt about their common parentage. They all have a short, coneshaped bill which is slightly flattened on the sides and covered up to the nostrils with small feather's which bristle easily and give an impertinent expression to their physiognomy. Ill titmice too have very rolust muscles in the neek; their skull is rery thick; they also have much strength in the muscles of their feel and toes: Ihis explains the suppleness and agility of their wonderful gymnastic feats, when they destroy caterpillars on the branches, pick hard seeds and piere the shell of hazelnuts. It has even been said that they take advantage of the sharpness of their bill. which can be compared to a blade of steel, in order to pierce the skulls of small birds when they find them either dead or weakened by illness, so as to feast on their brains. Ordinarily howerer, titmice are satisfied with more innocent food; they live chiefly on caterpillars, egg's of butterflies, hut also on hazclnuts, beech-nuts, walnuts, and in general on all kinds of oil-seed.

During the fine season they live in the deptlis of hilly woods, but as soon as the first cold sets in and the first snow falls on the mountains, they emigrate towards cultivated plains and draw nearer to inhabited regions. Nearly all titmice are remarkable for their talent in nest-building, which is truly extraordinary in such small birds. They employ in the construction of their 
nest choice material, such as small blades of grass, flexible rools, soft silky moss, bits of wool, feathers and regetable down, and they use their bill in a most skilful manner for interweaving, rounding off, smoothing and shaping these materials so various in texture and in form.

Titmice are all very prolific. Iost of the females lay as many as fifteen or even eighteen eggs. Their family instinct is also very much developed. Both males and females display untiring zeal in feeding their large progeniture and unequalled energy in defending it against the attacks of owls and other rapacious birds. In the main, the disposition of titmice is naturally violent, daring and warlike.

It is doubtless due to their intrepidity and quarrelsome temper dereloped by the obligation of being ever on the defensive, that titmice have sometimes been accused of slyness, cumning and ferocity. But on the contrary it seems to me that we ought to admire the courage with which these birdlings fight the hard struggle for existence. Their fondness for live flesh has often been east at them as a reproach, live flesh which they tear with their nails just like the shrike and the raven; but one is apt to forget that their small body is only a bundle of muscles and nerves and needs very substantial food to resist the wear and tear of life. Their constitution demands the assimilation of a great quantity of animal food. Why do we not cast the same reproach at the nightingale which also lives on bleeding flesh? 
As to the cunning of titmice, is not that a light fault indeed in this wee bird which disappears in the bigness of the great forest, where it is constantly obliged to defend itself and family against the attacks of such marauders as the night-owl and the squirrel? Pheasants too are sly and cunning, but this takes away none of their solid and raliant merits. If perchance, pressed by famine a titmouse pierces the skull of a dead or dying bird, it is not we, who are such ferocious lunters and anglers, who have the right to cast this into its teeth or to accuse it of a crime.

To eat or to be eaten is a terrible dilemma, which does not allow him who is driven into it, to give himself up to excessive sensibility. I should like to see those moralists who accuse titmice of cruelty, thrown without food or clothing into a wilderness, and under the necessity of getting their food by the strength of their nails!...

The truth is that titmice are very sociable. Whether they have a taste for society, or whether the sense of their weakness makes them rongregate together, is more than we can say ; but it is sure that they are fond of the society of their equals and take their flight in larger or smaller troops. When perehance some accident has separated them, they quickly utter their call and are promptly reunited.

Whilst I was meditating on the faults and qualities of ritmice, I happened to be an eye-witness to a sample of those beautiful relations which are established among the different members of this family. 


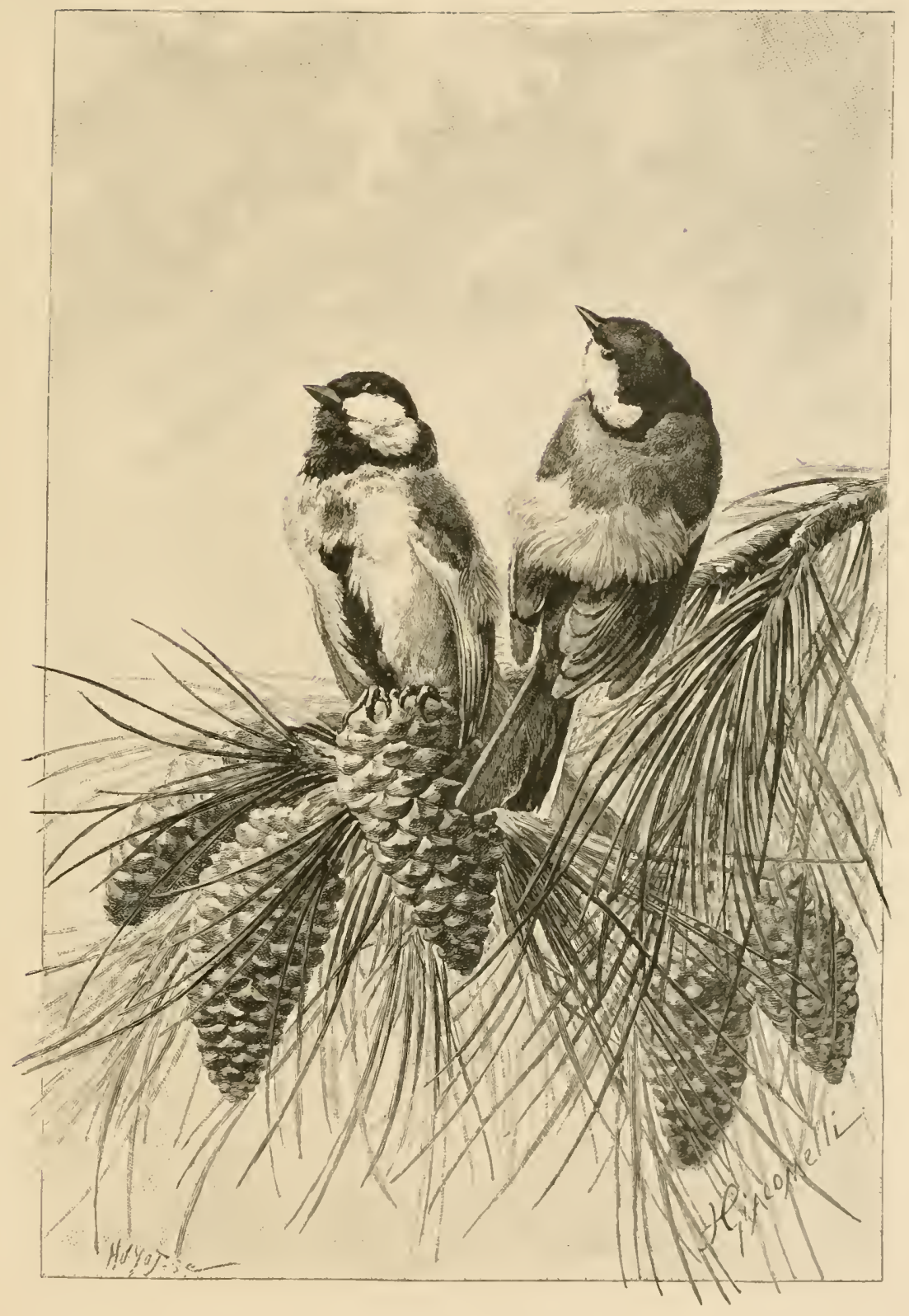

THE TITMOCSE 

In the pines and firs, in the hawthorn and barberry bushes already stripped of their leaves which I could see from my window, all the different species of titmice were represented, seeming to live in perfect harmony. They formed various groups, all very busy and very restless. To class them all by name one by one would require a numbering almost after the fashion of Homer.

There was the great black-headed titmouse easily rerognised by its square build, its black hood and black breast-plate. When the weather is unsettled and it is going to rain, it utters a ery which is like the grinding of a file on a piece of iron, whence one of its French surnames: la serrurire (the locksmith). But generally it has a pleasing warble, especially in the season of love. It builds its nest in the holes of walls, in the trunks of trees, sometimes also in coal-sheds abandoned by coal-burners.

Beside the great black-headed titmouse, the blue titmouse is very busy, the prettiest, the boldest, the bravest of the family; - it is a lovely bird with its delicate head covered by a blue hood, its bluish wings, its white cheeks and its dark blue collar. This bird is the most terrible destroyer of caterpillars. It has been calculated that it eats daily half an ounce of eggrs of butterflies.

Then comes the ash-coloured titmouse or mun, which stores away seed in its hole and makes war on wasps; then the great titmouse. which weares its mossy nest in a marvellous manner, and suspends it on the bough of trees 
just like the gold-hammer ; - lastly, the long-tailed titmouse, with its rapid, elegant flight which can only be compared to the shooting of an arrow.

All these minute folks were hopping, skipping and springing about and warbling peacefully in the green boughs. Suddenly the whole troup took wing with a startled cry; at the same time the report of a gun was heard. I recognised there one of those finely characteristic traits of man, that mild and benevolent animal who is so very much shocked by the ferocity of titmice. Fortunately these birdlings are wise and experienced; they had foreseen the shot and had taken wing in time.

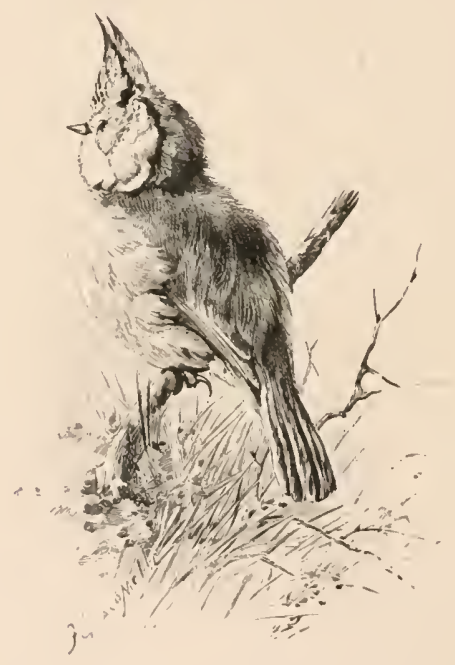




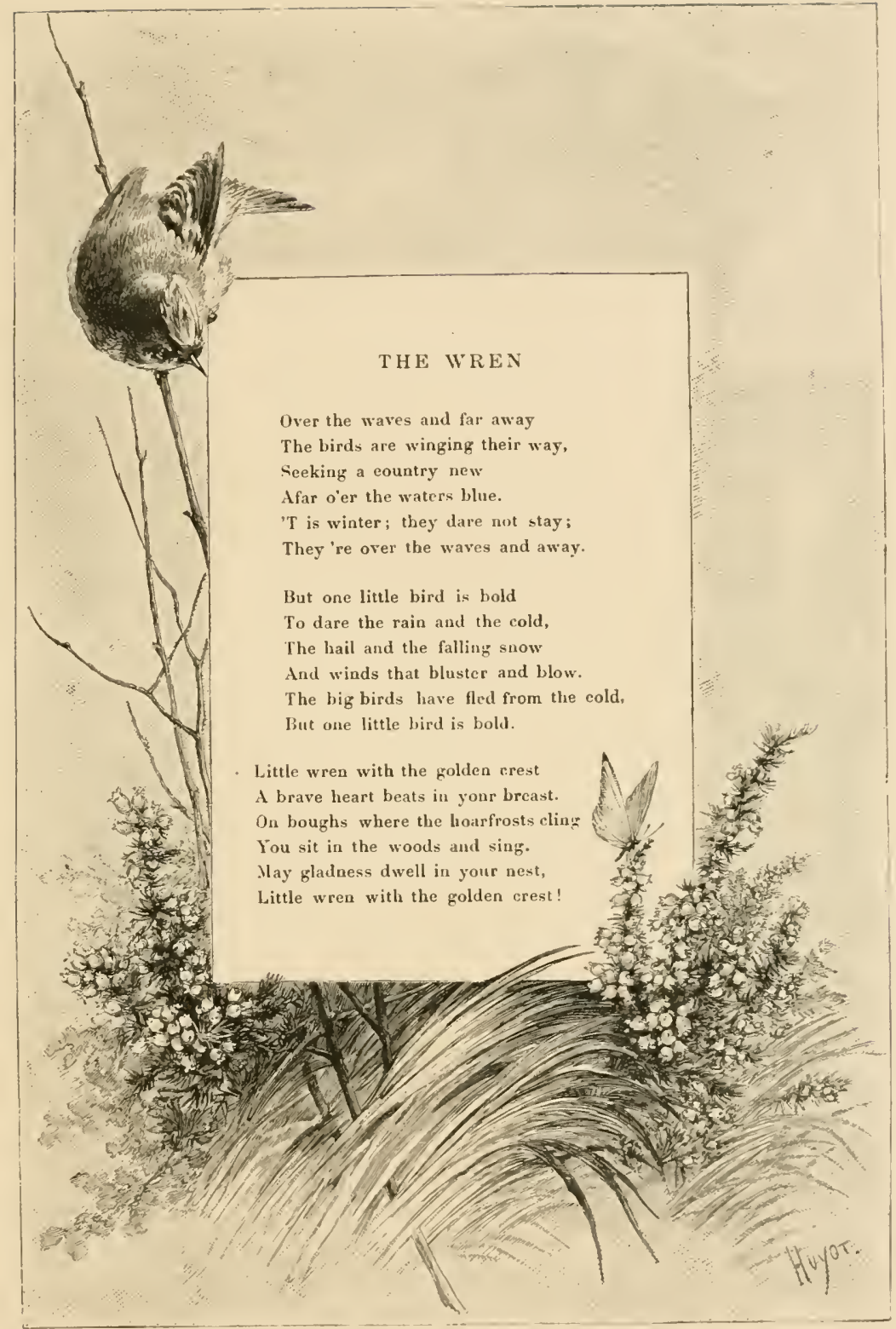





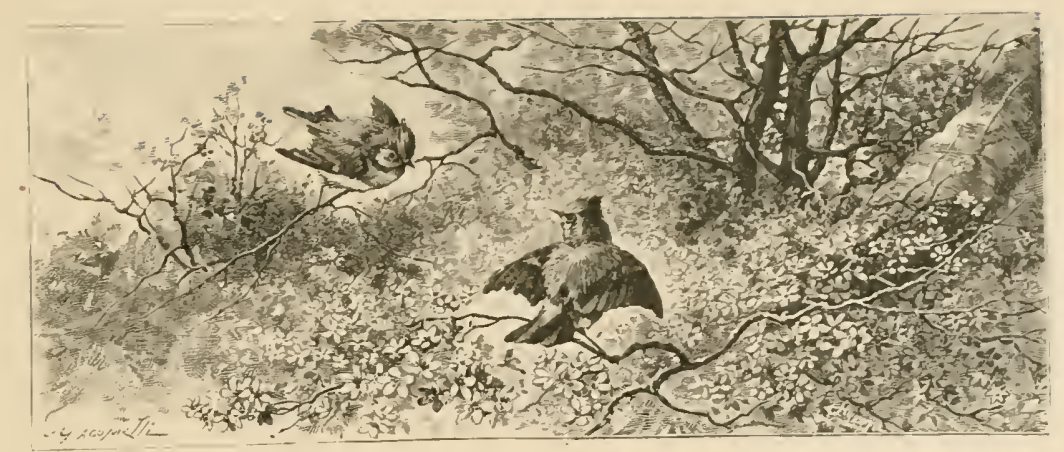

\section{THE IVREN AND THE TROGLODY'TE}

I found one day a marvelously constructed nest in the boughs of a larch tree Imagine a large ball, delicately woven of moss and gossamer threads, wadded inside with the wallmest and softest down, gathered from the catkins of poplars, the ripe tufts of thistles and the cottony seed of the willow herb. This soft nest, into which one could only penetrate on one side by a narrow opening, was the work of the golden-crested wren, that liliputian bird, the smallest of our European birds.

The wren is yet smaller and more delicate than its cousin the troglodyte, with which it is often confounded, although the two birds differ in manners, plumage and 
song. The troglodyte is about an inch longer than the golden-crowned wren; its plumage is shaded off firom dark brown to black, like that of the woodcock; its tail is constantly turned up like a plume of feathers; it sings moreover a merry, melodious strain. It builds its nest anywhere, sometimes close to the ground, on some bough covered with dense foliage; sometimes under the thatehed roof of some lone cottage, and even sometimes on the hut of a coal-burner or maker of wooden shoes, who carry on their trade in the hear $t$ of the forest. Their nest consists of a ball of moss, shapeless on the outside, but very skilfully lined with feathers on the inside. In this soft nest the female lays nine or ten eggs of a dull whitish colour spotted with red at the hroader end. As soon as the young ones are feathered, the family scatters and disperses in the forest.

The troglodyte lives in secluded retirement, in bushes and thickets. There it flutters about until night has set in, and it is, with the red-breast and the blackbird, one of the last birds whose song is heard after the sum has set. It is not shy, and the neighbourhood of man does not annoy it in the least. I remember laring met a troglodyte in the forest of Compiègne, which was fluttering about between the entangled branches of a sloe-tree, and it did not seem at all disquieted by my presence. It went on humming, singing with a clear voice, turning up its small tail, agitating its wings, and passing through the thickets 
and briers with the vivacity of a lizard. When winter is drawing near, this small birdling remains in the neighbourlood of farms and orchards, ever singing merrily, in spite of cold and in spite of snow. "It is never melancholy, says Belon; it is ever ready to sing; one is sure to hear it at morn and at night from a distance, and generally in winter time, and its song then is scarcely less loud than that of the nightingale. "

The bird to which the troglodyte bears the closest resemblance, in roice and in habits, is the small willowwren or pewet. The pewet is of the same size as the wren; it has also the same plumage, with the exception of the crest; but it has the habits and general bearing of the troglodyte. Like the latter, it feeds on worms and flies, which it pursues with astonishing viracity. The female lays generally five or six white eggs, with russet-coloured spots. The young ones do not leave their mossy bed till they are able to fly. In Autumn, the pewet imitates its cousin the troglodyte; it abandons the large forests and begins to flutter near orchards. Its song consists of long shrill notes, with varied modulations; it begins with a sort of syncopated murmur; then come some silvery notes, clear and distinct; lastly, a very sweet, sustained warbling, which, especially in Autumn, finishes off in a loud whistle: tuit! tuit! and which is like the characteristic signature of this diminutive virtuoso.

The golden-crested wren, on the contrary, scarcely 
ever warlyles excepting at the time of brooding; at all other times, it utter's only a sort of single shrill cry which is very much like that of the grasshopper. But if it does not shine by its song, it makes up for this imperfection by wearing on its forchead the ladge of royalty. Its plain hrown plumage is set off ly a beautiful gold coloured crown. This crest consists of moveable feathers which the wren, by means of certain muscles in the head, can raise or lower at pleasure. The erest is edged with black; a white line at its basis, a black trait on both sides of the eyes, mark yet more the comageous and resolute mien of this miniature monareh.

And indeed the golden-crowned wren is full of vivacity and energy: there is not a bird who undertakes more bravely the strugghte for existence. In summer's sme, in winter's cold it slips with intrepidity from tree to bush, from bush to blade of grass. shelling the yellow grain of fennel seed, cleiring the needles of the lareh tree, pieking in the ereviees of the bark of willows to find larvae of inserts or egges of bullerflies.

It is exceedingly fond of biting off young leaves from the boughs of the trees of the pine family : pines, fir trees, juniper trees, which enceal a whole world of larvile and eggs between their needles. The wren is a master in the art of destroying caterpillars. It has been calculated that a golden-crested wren can devour yearly three millions of eggs and of chrysalides. 


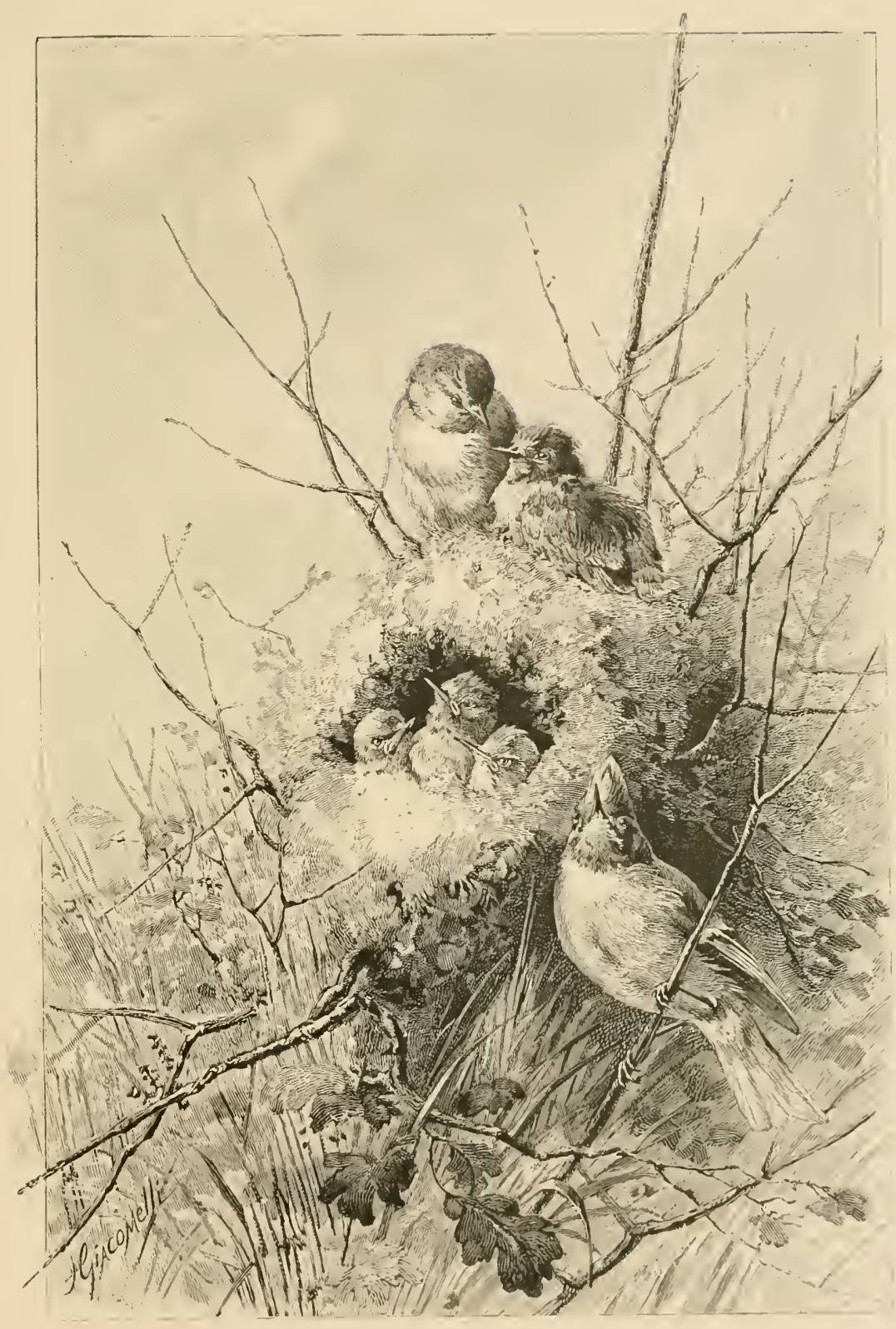

THE WREN 

It differs in this from the troglodyte : it pursues its occupations, followed by its whole family, with order and method. The whole band flies from one tuft of shoot to the other, in a certain direction determined by a special instinct of migration. An ornithologist, who is known as a close observer of nature, $\mathbf{M}$. de la Blanchère, has told us in his interesting book about l'seful and moxious birds, that he had succeeded in knowing well by which side a golden-crested wren had entered into a forest, and also in which regions of the forest he would unfailingly meet these little birdlings all winter long.

The golden-crested wren is fond of large trees. It suspends its nest beneath some forest pine tree, in whose boughs the wind sings such melodious strains, or else beneath the majestic fir of the V'osges, all bordered with lichen. In this nest, rocked by the waves of the big forest, the female lays from seven to eleven yellowish brown eggs, about the size of green peas. Now-a-days, only low people or kings can afford the luxury of such large families.

In its small body, the golden-crowned wren combines at the same time royal and plebeian blood. By its size, its industrious habits and its good humour, it belongs to the people; but it wears a crown and reigns in the forest in a fashion of its own. It enjoys a sort of mysterious, intangible royalty, which can only be compared to that of Queen Mab or to that of Oberon. In the Large, sleeping 
forest, the golden-crowned wren represents movement and life. When the frozen brooks are silent, when not a blade of grass is moving, when the wood-cutter warms his fingers by blowing on them before taking up the hatehet, he hears suddenly a lighte merry ary and sees a lovely. dimimutive apparition, crowned with a crest of gold, ghliding between the bare boughs. It is the familiar spirit of the bign forest, the beantiful golden-crowned wen, which lally lis at the bleak north wind, and continues picking cateppillatrs from the juniper trees, almost buried in snow.

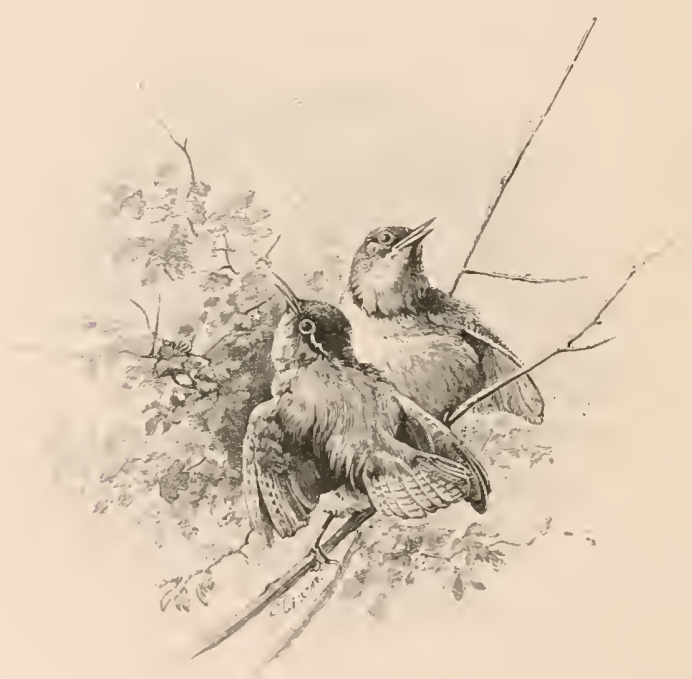




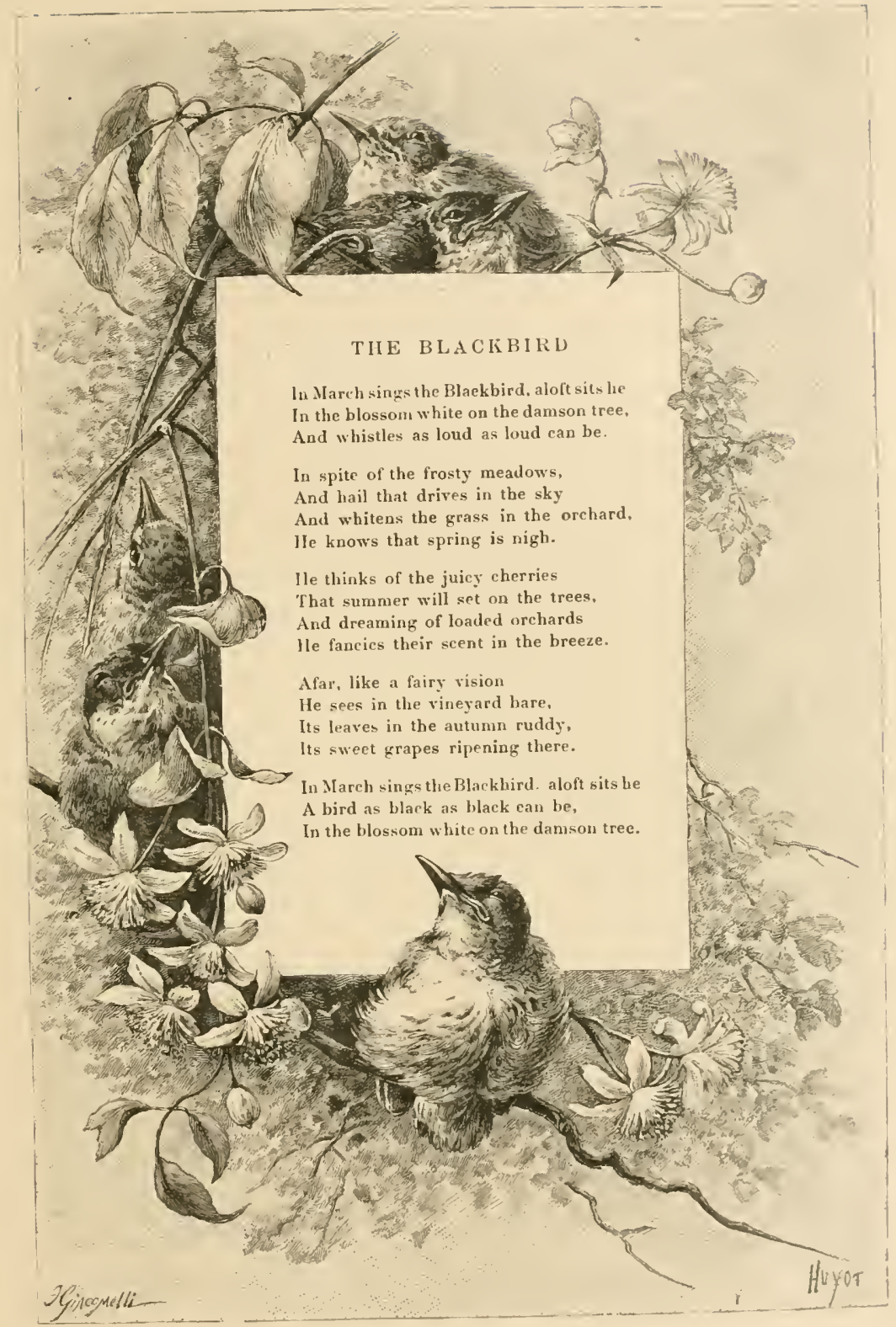





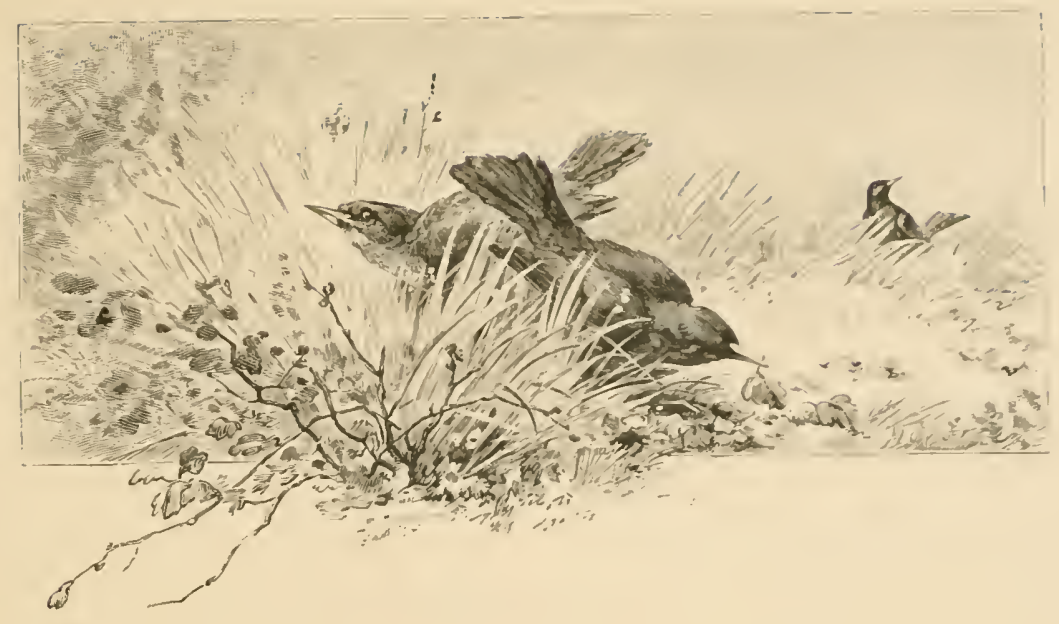

THE BLACKBIRD

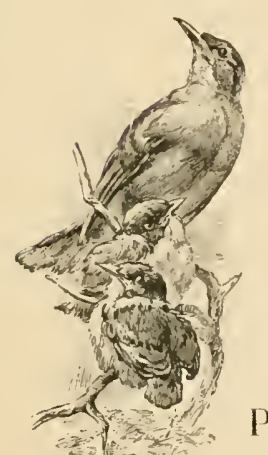

Every one knows that joyous fellow, even Parisians who have never much lived in the country, for it is the guest of all Paris gardens and squares. Every-where, in the Luxembourg and Tuileries gardens, in the Parc Monceau, you can sce them skipping and hopping about in the flowerbeds or on the zawns, nimble and alert, and easily recognized by their fine shiny black costume and their yellow bill. The female almost always accompanies the male, her costume is grey; she is as discreet, rescrved and silent as he is talliative

The blackbird is not a bird of passage, but a sedentary one; even in the sererest cold it remains in our 
lands. In winter, in cities, it is fond of haunting the neighbourhood of dwellings, where, among the green boughs of the gardens, it is always sure to find shelter and some sort of food.

When the country blackbirds feel that winter is setting in, they scek a refuge in the very depths of the forest, within reach of some tepid spring, beneath some pines or juniper trees, which offer them, better board and lodging. As soon as the cold is less intense they become very merry and begin, already early in February, to utter that joyous whistle which resounds so merrily in forest thickets and parks, when chestnut catkins begin to bloom. They build their nest very early, and if the first brood does not live on account of the cold, the female is not discouraged and begins to lay her eggs a second time. They build their nest nearly even with the soil, or sometimes in the hollow of some old willow. Their nest bears a great resemblance to that of the thrush ; it is made of solid masonry and woven very dexterously; a layer of clay covers it on the outside, on the inside it is lined with grass and roots, and again with soft moss. The female lays four or five bluish green eggrs, spotted with rust. She broods them alone, while the male is fluttering to and fro, whistling merrily and searching at the sams time for food; this he brings back to his mate after having divided it into pieces.

The disposition of the blackbird; is very jovial ; it is 
so to say the wag of the world of birds. It has something of the animation and the crack spirits of a clown or a low actor, and like these merry-makers it needs a gallery to listen to it and to applaud it. It is very fond of society, but prefers to the companionship of its brethren, that of smaller birds of different specics. Often, towards evening, I have observed the manceuvres of blacklirds on the large lawns of the Luxembourg. Each one would skip lightly over the grass, escorted by four five familiar sparrows, that seemed to be very proud of being admitted into the intimacy of the fine blackbird with its handsome black dress. The latter, meanwhile, would skip to and fro, with a mien of self importance and condescension; it seemed to take great pleasure in astonishing the "small fry " which it consented to admit into its company. It appeared to me like one of those witty wags who are at the same time vain, noisy and vulgar. who disdain their equals and only find themselves at ease in the company of persons they can dazzle and over whom they can lord it easily.

The blackbird is fond of showing himself in public; he likes to have all the talk to himself, and makes himself everywhere at home very unceremoniously. I remember having witnessed one morning in autumn a most amusing scene, in which a blackbird played the chicf part. On the outskirts of a vincyard, a blackbird, drunk with grape juice, was parading near me, accompanied by half a 
dozen thrushes. The wag, merrily inclined, was perched on top of one of the vine-poles giving a performance for the benefit of his merry followers. He twinkled his eyes, fluttered his wings, agitated his tail, put his head between his feet, with a grotesque mien, which greatly amused his lady spectators, very attentive to all that was going on.

And besides, autumn is a scason of high glee and merry-making for the blackbird. The orchards are full of stone fruit, wild herries are abundant in the hedges, the grape-vines are loaded with grapes. Therefore, it cares no longer for worms or insects; it stuffs itself with the pulp of sweet-scented, juicy fruit. It has no other care but that of satisfying its greediness : love is no longer one of its torments, and it has become silent. It only utters a sort of ill-humoured sound, when disturbed whilst taking its dinner.

But the finest of holidays will come to an end. One by one, the fruit-trees lose their leaves and their fruit; the grapes are gathered. There is nothing more to steal on bush or hedge but a few berries on the sloe tree and in the thickets, already covered with hoar frost. Now the long days of feasting are orer; the blackbird must be satisfied with less abundant fare. At the end of Norember, the last wild berries have disappeared with the frost... Good bye, juicy fruit.

The blackbird now retreats towards the big clumps of trees and establishes itself in its winter quarters. There, 


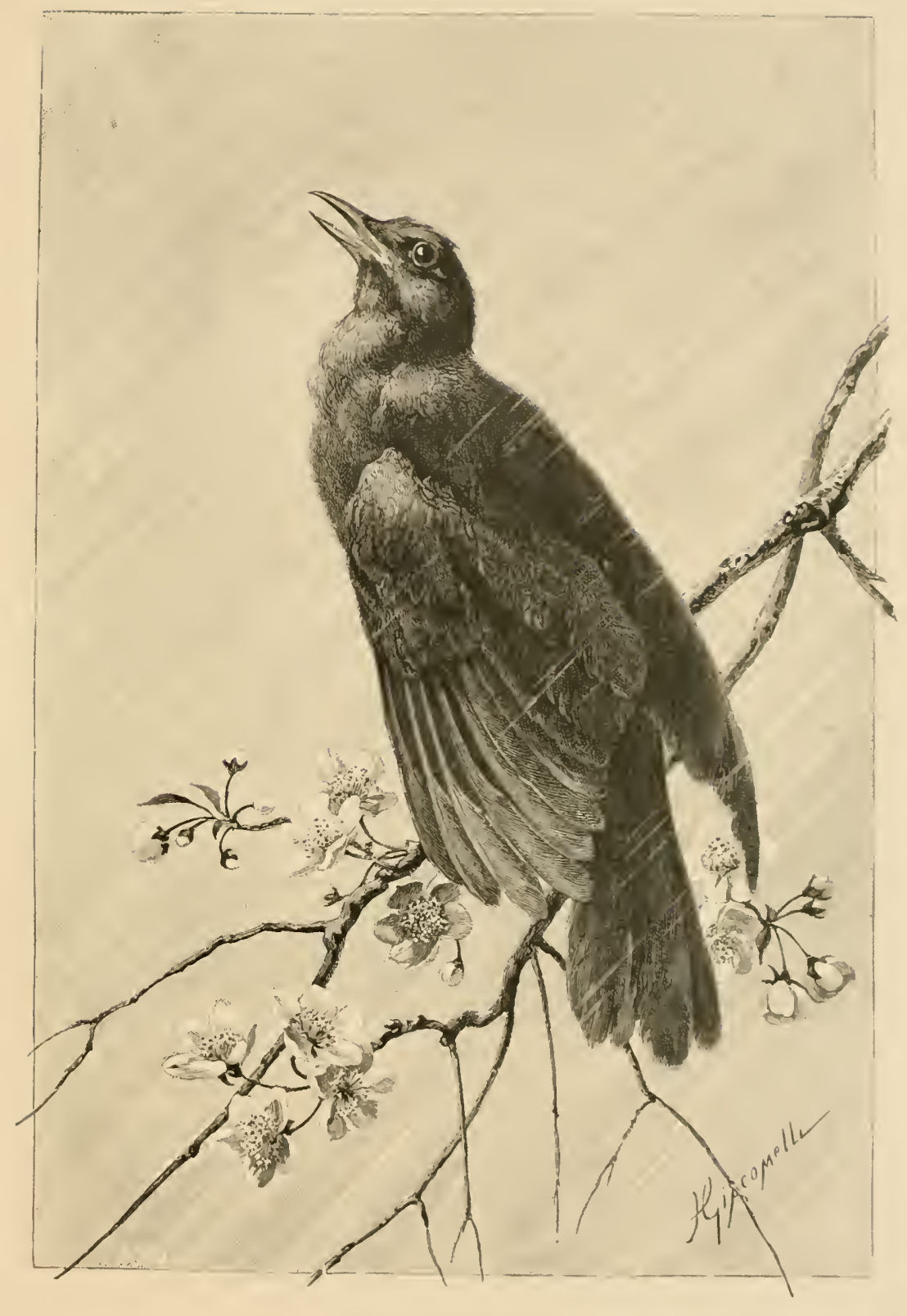

THE BLACKBIRD 

the fare is but middling and the society it meets not very amusing. The time of merry-making is over. My Lord Blackbird is obliged to come hack to the dict of (nrub) and worms, and even these are not always found in sufficient quantity. All his boon companions, beingr afraid of cold, have emigrated towards warmer climes. Ilis nnly society are titmice, whom we know as cross-grained, peevish, and positive people; husy birds, indeed, little inclined to listen to the fooleries of the blackbird: he also finds golden-crested wrens, who being of a reserved disposition, fly from the vicinity of our big noisy blackbird.

Happily, he is a philosopher. He repeits to himself for his own beneft all his waggish tales, like an nld, long forgotten actor who plays orer again for himself all those scenes in which he used to be applauded in his best days. And then he consoles himself hy saying to himself that bad days will pass by as well as happy ones, and that after all, winter is not everlasting. Already at the end of January he perches on the topmost branch of a fir tree and watches attentively the lengthening days and the rising temperature. On Saint-Antony's day days a lengthen the length of a monk's meal, » and at Candlemass " they lenethen an hour s; and with all that the latter end of winter is at hand. By a peculiar instinct, midst rainshowers and February storms, the blackbird knows that spring-time is near. It sees the catkins on hazel-nut trees growing longer; it sees that in the thickets the black hellebore is 
opening its green corollas edged with rose colour: on all sides, in every nook and corner the woods seem to say: "Spring hils returned! »

In its heart of hearts the blackbird feels it also. In its breast the desire of love is budding, just as buds are appearing on the boughs, and suddenly it begins to whistle merrily. That alert whistle which resounds in the silent, deserted forest is the first note on the fiddle which gives the signal of the ever renewed, ever enchanting symphony of spring.

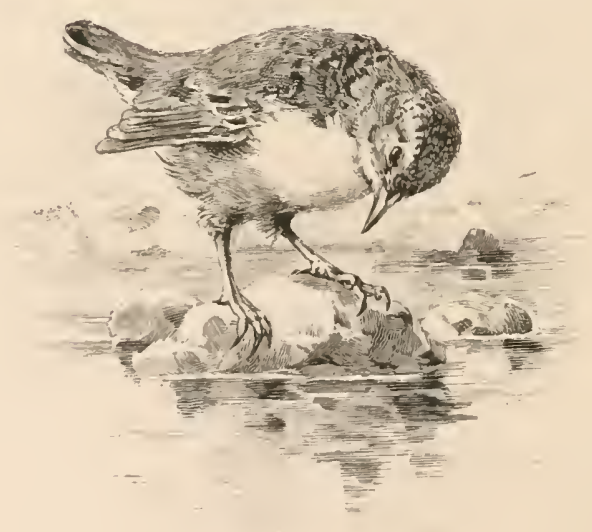






